Universidade de São Paulo

Faculdade de Economia, Administração e Contabilidade

Departamento de Administração

Implementação de Projetos de Modernização Administrativa Municipal suportados pela Tecnologia de Informação:

Estudo de Casos em Municípios do Estado de São Paulo

Marcos Paulo Spinelli

Orientador: Prof. Dr. Hiroo Takaoka

São Paulo 
Reitor da Universidade de São Paulo

Prof. Dr. Adolpho José Melfi

Diretor da Faculdade de Economia, Administração e Contabilidade Profa. Dra. Maria Tereza Leme Fleury

Chefe do Departamento de Administração

Prof. Dr. Eduardo Pinheiro Gondim de Vasconcellos 
Universidade de São Paulo

Faculdade de Economia, Administração e Contabilidade

Departamento de Administração

\title{
Implementação de Projetos de Modernização Administrativa Municipal suportados pela Tecnologia de Informação: \\ Estudo de Casos em Municípios do Estado de São Paulo
}

\begin{abstract}
Dissertação apresentada ao Departamento de Administração da Faculdade de Economia, Administração e Contabilidade da Universidade de São Paulo - FEA/USP, como requisito para obtenção do título de Mestre em Administração.
\end{abstract}

Marcos Paulo Spinelli

Orientador: Prof. Dr. Hiroo Takaoka

São Paulo 


\section{Ficha Catalográfica}

Spinelli, Marcos Paulo

Implementação de Projetos de Modernização Administrativa Municipal Suportados pela Tecnologia de Informação: Estudo de Casos em Municípios do Estado de São Paulo.

/ Marcos Paulo Spinelli. -- São Paulo, FEA/USP, 2003.

$88 \mathrm{p}$.

Dissertação - Mestrado

Bibliografia.

1. Informática - Administração 2. Serviços Públicos Eletrônicos 3. World Wide Web 4. Tecnologia da Informação 5. Administração da Informação 6. Administração Pública I. Faculdade de Economia, Administração e Contabilidade da USP. II. Implementação de Projetos de Modernização Administrativa Municipal suportados pela TI: Estudo de Casos em Municípios do Estado de São Paulo.

CDD - 658.4038 


\section{DEDICATÓRIA}

Primeiramente a Deus Nosso Senhor sempre presente e generoso, de forma muito especial a minha amada esposa Carla e a minha querida filha Sophia, pela compreensão, paciência e incentivo durante os anos dessa jornada. Muito obrigado por tudo.

Vocês são meu maior tesouro. Amo vocês com todo meu ser. 


\section{AGRADECIMENTOS}

Ao Departamento de Administração da FEA pela oportunidade, disciplinas e facilidades oferecidas.

Ao Prof. Hiroo e sua equipe, pelo apoio, incentivo, cobrança e orientação.

Ao Prof. Vidal e ao Prof. Nicolau, por mostrarem caminhos e me incentivarem a realizar este trabalho.

Ao meu irmão José Eduardo, meus pais Cláudio e Irene, familiares e amigos queridos, pelo apoio, acolhimento e incentivo por todo este período.

A minha amada esposa Carla e minha querida filha Sophia, pela compreensão, incentivo e paciência durante os anos dessa jornada.

Finalmente, a todos os colegas e amigos que colaboraram com as entrevistas e outras fontes que subsidiaram esta pesquisa. 


\section{SUMÁRIO}

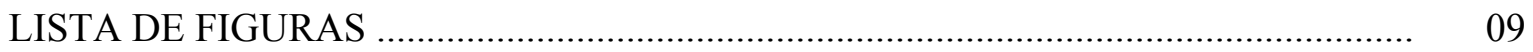

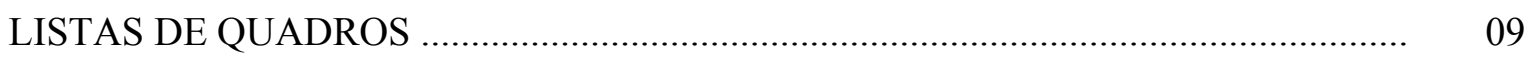

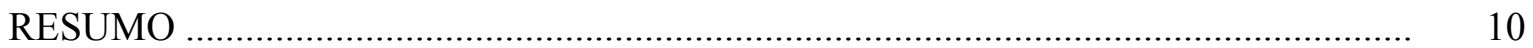

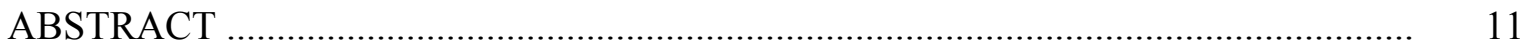

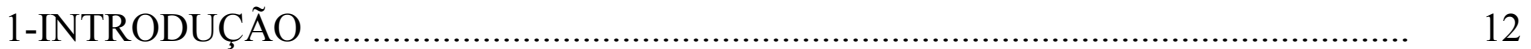

1.1-Definição do Problema de Pesquisa................................................................................ 19

1.2-Justificativa do Estudo ............................................................................................ 20

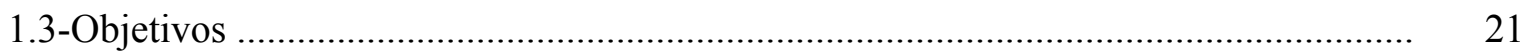

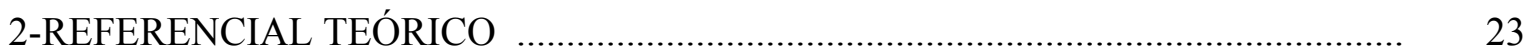

2.1-Administração pública e Administração tributária .................................................... 28

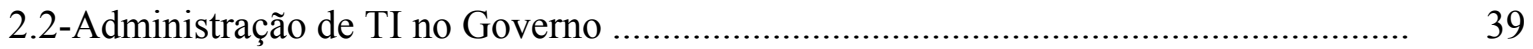

2.3-Gerência de projetos e Processo de implementação de projetos de TI ....................... 54

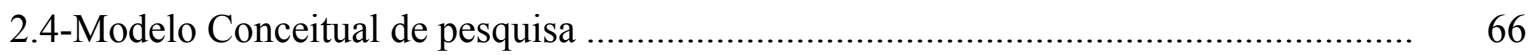

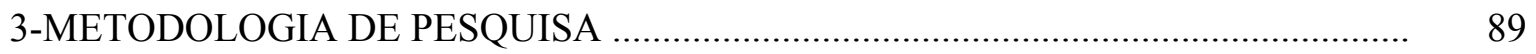

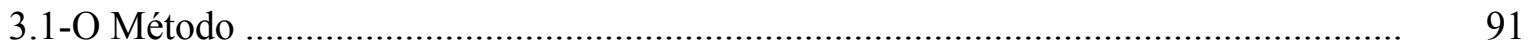

3.2-Organização e desenvolvimento da pesquisa ................................................................ 97

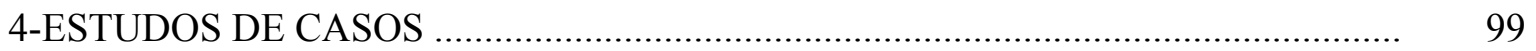

4.1-O Caso da Prefeitura de São Paulo................................................................................... 99

4.2-O Caso da Prefeitura de Santo André ............................................................................ 117

4.3-Análise entre os Casos à luz do referencial teórico ..................................................... 137

5-CONCLUSÕES E RECOMENDAÇÕES................................................................ 148

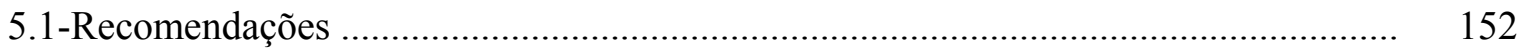

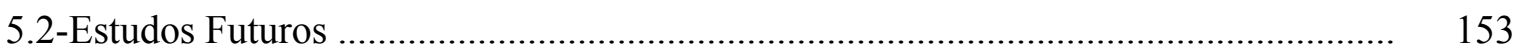

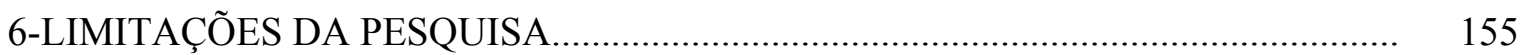

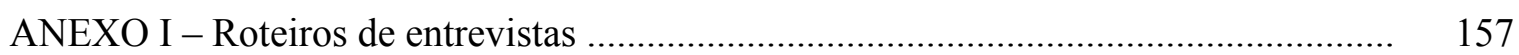

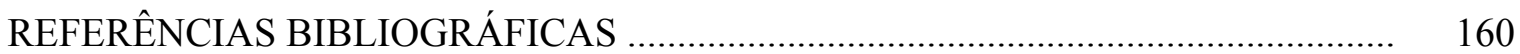




\section{LISTA DE FIGURAS}

FIGURA 01 - Organização da revisão bibliográfica ........................................................... 23

FIGURA 02 - Quatro perspectivas do governo digital ...................................................... 26

FIGURA 03 - Taxonomias para "Governo Eletrônico" ......................................................... 27

FIGURA 04 - Modelo Integrado de "Comércio Eletrônico" ................................................ 45

FIGURA 05 - Interação entre os grupos envolvidos na Utilização da

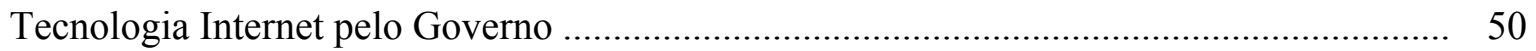

FIGURA 06 - Modelo para Utilização da Tecnologia Internet pelo Governo ...................... 51

FIGURA 07 - O relacionamento entre tecnologia, pessoas, tarefas e estrutura .................... 61

FIGURA 08 - Alinhamento dos componentes de uma organização ..................................... 64

FIGURA 09 - Modelo lógico de aplicação de Netto ............................................................. 79

FIGURA 10 - Caminho para implementar governança apoiada pela TI .............................. 85

FIGURA 11 - Organograma da Secretaria de Finanças e Desenvolvimento

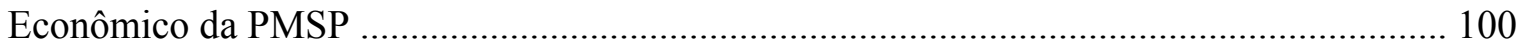

\section{LISTA DE QUADROS}

QUADRO 01 - Do cartão perfurado à Internet ................................................................... 44

QUADRO 02 - Estrutura da análise de "Comércio Eletrônico" .......................................... 46

QUADRO 03 - Conceitos críticos para inovação …………………………....................... 62

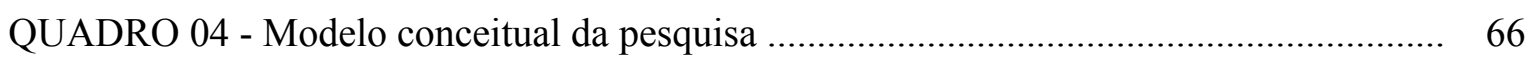

QUADRO 05 - Análise SWOT - Aspectos Políticos ........................................................... 82

QUADRO 06 - Análise SWOT - Aspectos sociais ............................................................ 83

QUADRO 07 - Análise SWOT - Aspectos econômicos ………………………………....... 83

QUADRO 08 - Análise SWOT - Aspectos tecnológicos .................................................... 84

QUADRO 09 - Implementando o governo suportado pela TI - 1: VISÃO ......................... 86

QUADRO 10 - Implementando o governo suportado pela TI - 2: ESTRATÉGIA …......... 87

QUADRO 11 - Implementando o governo suportado pela TI - 3: PROJETOS ................. 88

QUADRO 12 - Condições e fontes de evidência da Pesquisa ............................................. 97

QUADRO 13 - Resultados já alcançados com a implantação da Rede Fácil ...................... 124

QUADRO 14 - Resumo dos fatores condicionantes destacados pelos respondentes .......... 140 


\section{RESUMO}

A dissertação apresenta uma pesquisa qualitativa e exploratória sobre o tema da Implementação de Projetos de Modernização Administrativa Municipal suportados pela TI - Tecnologia de Informação e tem como objetivo maior identificar os principais fatores facilitadores e dificultadores deste processo na administração financeira e tributária de municípios paulistas.

A partir de uma revisão bibliográfica que abrange os principais aspectos teóricos, buscou-se construir e validar um modelo conceitual de pesquisa para subsidiar o estudo de projetos de modernização na área pública, levantando e analisando forças e fraquezas, motivações e resultados percebidos, respondendo e discutindo de forma apropriada a pergunta-problema inicial.

Pela natureza da investigação foi utilizado o método do Estudo de Caso, tendo como unidades de análise as administrações municipais de Santo André e São Paulo. Os dados da pesquisa foram coletados através de entrevistas focadas realizadas pelo próprio pesquisador junto aos gerentes de projeto, complementadas por outras fontes de evidência como observação direta e documentação disponível. 


\begin{abstract}
In the present work, it has been conducted a qualitative and exploratory analyses on the major of the Modernization in the Municipal Administration. Technology of Information supports the implementation of this project, and, the principal objectives are to identify not only pros aspects but also con factors. Furthermore, these studies highlight the importance of the financial administration and taxes control of cities within São Paulo state.
\end{abstract}

A well-conducted bibliographic research was undertaken in order to cover the main theoretic aspects involved. In addition to that, it is proposed a conceptual model of searching, so that it is possible to resolve the problem established.

The Municipal Administrations of São Paulo and Santo André were assumed as units of investigation. All data had been collected throughout proper interviews and other pieces of evidence such as direct comment and original documentation. 


\section{1-INTRODUÇÃO}

Conforme Backus (2001), as soluções para questões de desenvolvimento normalmente exigem mudanças nos processos do governo, por exemplo, através da descentralização. Os objetivos são geralmente melhorar a eficiência e a eficácia e reduzir custos. As forças direcionadoras destas mudanças podem ser a demanda pública por serviços e informação "on-line" visando aumentar a participação democrática, a prestação de contas, a transparência, a qualidade e a velocidade dos serviços.

A implementação de soluções de TI pode suportar as reformas do governo. A utilização da tecnologia Internet pelo Governo tende a tornar-se mais e mais atual em todo do mundo em poucos anos já que a maioria de países está em estágios adiantados do chamado "Governo Eletrônico". Um bom começo foi feito na Europa, EUA e em outros países como Austrália e Cingapura, servindo de referência para beneficiar e desenvolver outros países e seus cidadãos.

Imagine uma situação em que toda a interação com o governo possa ser feita 24/7 (24 horas por dia e 7 dias por semana) sem necessidade de buscar atendimento nos escritórios de governo. No futuro próximo isto será possível se os governos se dispuserem a descentralizar responsabilidades e processos e começarem a usar meios eletrônicos tais como o Internet. Cada cidadão poderá então relacionar-se com o governo através de um site onde todos os formulários, a legislação, notícias e outra informação estejam disponíveis 24/7.

Conforme Backus (2001), em todo o mundo, os bancos comerciais já trabalham de acordo com este conceito e somente em algumas situações muito especiais se precisa ir até uma agência física. A maioria das transações podem ser feitas pela Internet, tendo como consequência enorme redução de custos, ou seja, realiza-se mais atendimentos, com menos pessoal, em menos tempo e com menos e menores escritórios. O governo, como coletor e fonte de informação, deveria também seguir esta tendência a fim de servir mais melhor a seus clientes (cidadãos, empresas e outros grupos de interesse), reduzindo o consumo de recursos públicos e diminuindo custos fazendo operações internas mais eficientes.

Existem muitas definições para o chamado "Governo Eletrônico". Antes de apresentar uma definição completa, pode-se entendê-la como instrumento democrático ao disponibilizar tecnologia de consulta aos processos e às estruturas que abrangem todos os formulários do relacionamento entre o governo (eleito) e o cidadão (eleitorado). Implementa-se formulários eletrônicos via Internet para entregar serviços eletrônicos ao público (cidadãos e empresas) e suportar transações eletrônicas da conduta dentro e entre órgãos públicos. 
O objetivo estratégico da utilização e implementação de tecnologia Internet pelo governo é suportar e simplificar os serviços públicos para todos os envolvidos: governo, cidadãos e empresas. O uso da TI pode conectar todos os três grupos de interesse e suportar processos e atividades. A boa governança pode ser entendida como um exercício da autoridade econômica, política e administrativa para melhor controlar um país em todos os níveis, nacional e local. É útil apresentar os objetivos de fornecer aos cidadãos a informação e o conhecimento sobre o processo político, sobre serviços e sobre sua escolhas (Backus, 2001)

A utilização da TI nas operações do governo facilita a rápida interação, transparência, prestação de contas, eficiência e eficácia com o público, os cidadãos, as empresas e outros governos (objetivos estratégicos externos) e para executar atividades da administração do governo com economia de custo significativas (objetivos estratégicos internos). Pode-se concluir que o chamado "Governo Eletrônico" é mais do que apenas um site do governo no Internet, os aspectos políticos, sociais, econômicos e tecnológicos é que determinam sua implementação.

Sem dúvida alguma, o sucesso de "Governo Eletrônico" anda, pari-passu, com o sucesso da reforma do próprio Estado. Em verdade, são dois conceitos complementares. Por outro lado, difícil se torna esperar resultados efetivos, eficazes e eficientes de um "Governo Eletrônico", se ele não se aproximar das demandas da sociedade e permitir o estreitamento de relações entre Governo e Mundo Empresarial. Fica cada vez mais claro que o governo digital não é simplesmente uma questão de tecnologia, mas de uma nova maneira de gerir pessoas e processos usando a tecnologia como ferramenta.

O uso pelos governos das novas tecnologias de informação na prestação de serviços e informações para cidadãos, fornecedores e servidores constitui o que se convencionou chamar de "Governo Eletrônico". Embora este termo faça uma associação mais estreita com a Internet, o seu conceito, num sentido mais amplo, compreende uma série de atividades que vão além da simples presença de unidades governamentais na grande rede. No Brasil, a melhor estratégia para a disseminação do uso da Internet na função pública e a definição de qual é o papel do Estado neste campo, vêm sendo objeto de crescente interesse e debate. Vários estudos indicam que tanto o governo federal quanto os governos subnacionais já estão consideravelmente envolvidos com a aplicação das novas tecnologias de informação na administração pública. Grandes dificuldades, porém, persistem. É o caso do desafio da ampliação do acesso da população, inclusive de baixa renda, à Internet no país. Há, ainda, a questão da baixa interoperabilidade entre os diversos órgãos da administração pública, o que dificulta se atingir estágios mais avançados de presença do governo na Internet, cuja superação depende de investimentos consideráveis na modernização administrativa da União, estados e municípios (Fernandes, 2001). 
Conforme Fernandes (2000), no que diz respeito aos municípios, em uma pesquisa recente realizada a partir de uma amostra de 83 cidades de São Paulo, Minas Gerais e Santa Catarina, estimou-se que, no âmbito municipal, $72 \%$ das prefeituras com mais de 200 mil habitantes já devem estar utilizando a rede para serviços e informações à população. A complexidade e a qualidade das informações prestadas aos usuários variam muito entre os "sites", e relativamente poucas prefeituras prestam serviços efetivamente em tempo real. Contudo, muitos municípios, especialmente capitais e os de regiões metropolitanas, já estão preparados para receber dados dos usuários.

Atualmente, um bom exemplo é o serviço SACnet do site da Prefeitura de Manaus, onde o contribuinte, através, de uma senha, consulta, tira dúvidas, atualiza dados cadastrais e acompanha processos junto à prefeitura. Serviço semelhante é oferecido por outras prefeituras, como a do Rio de Janeiro e Porto Alegre. Neste último site, entre outras coisas, é possível ainda realizar boa parte dos procedimentos para a obtenção de alvará, notificar um óbito e acionar um serviço funerário, acompanhar o tráfego da cidade, avisar sobre uma fuga de água, calcular o IPTU - imposto sobre a propriedade territorial urbana, obter a guia eletrônica para recolhimento do ICMS - imposto sobre circulação de mercadorias e serviços (que, contudo não pode ainda ser entregue via Internet).

No site da Prefeitura do Rio, é possível pedir certidões via e-mail ou ainda solicitar, via Internet, o serviço de um eletricista, bombeiro hidráulico, pintor, técnico de geladeira, etc, do Programa de Apoio do Trabalhador Autônomo. No site da prefeitura de Vitória é possível solicitar eletronicamente serviços, tais como, poda de árvores à secretaria de meio-ambiente, desobstrução de bueiros à secretaria de obras, cálculo de tributos devidos e parcelamento da dívida à secretaria da fazenda, envio de livros editados pelas secretarias da cultura e do esporte, etc. Solicitação de audiências com o prefeito também podem ser feitas pela Internet, bem como vários tipos de denúncias.

Estes são apenas alguns exemplos de "sites" e portais municipais. Na verdade, o grande problema, a nível municipal, são os pequenos municípios. Uma boa parte dos 5507 municípios brasileiros ainda não dispõem sequer de sistemas do nível local na alfabetização digital dos cidadãos. Sem o desenvolvimento de uma cultura local favorável à absorção das novas tecnologias de informação e sem a criação de postos locais de acesso à rede, muitos habitantes de pequenos municípios estarão simplesmente alijados da chamada nova economia, sem falar no considerável prejuízo ao exercício pleno da cidadania.

No mesmo sentido pode ser mencionado Cunha (2000): “o grande desafio do poder público é a inclusão do conjunto da população aos ganhos obtidos com o uso da tecnologia, não só na possibilidade de melhor prestação de serviços, mas principalmente pela inclusão do cidadão num 
mundo global onde não ter esse acesso pode vir a representar a exclusão da cidadania".

\section{Modernização do Setor Público}

De outro lado, a inter-operatividade entre os diversos órgãos da administração pública, sem a qual não é possível atingir estágios mais avançados de presença do governo na Internet, depende de investimentos consideráveis na modernização administrativa de estados e municípios. Isto pressupõe não apenas informatização de procedimentos, mas, sobretudo, treinamento e qualificação profissional dos servidores.

Isto só será possível se for realizada com êxito a modernização da administração pública, especialmente de estados e municípios. Programas como o PNAFE - Programa Nacional de Apoio à Administração Fiscal para os Estados Brasileiros, do Ministério da Fazenda/Banco do Brasil/BID e o PMAT - Programa de Modernização da Administração Tributária - do BNDES (Banco Nacional de Desenvolvimento Econômico e Social), são com efeito, pedra angular desse processo. Como para os outros aspectos da questão, cabe ao governo federal, também no que concerne ao financiamento, estabelecer uma política ordenada, mas sem implantação centralizada, respeitando o ritmo e as prioridades locais (Fernandes, 2001).

Conforme CRUZ (2001), desde o início dos anos 90, o BID - Banco Interamericano de Desenvolvimento, vem apoiando programas de modernização de órgãos públicos em 27 países das Américas. O Banco detectou basicamente três grupos de problemas que dificultam a execução das estratégias governamentais:

1-O planejamento estratégico não era uma atividade prioritária e institucionalizada e as áreas atuavam com pouca ou nenhuma integração entre si. Tampouco havia a tradição de acompanhar os resultados das ações.

2-As necessidades dos cidadãos e dos servidores não eram sistematicamente analisadas. Os primeiros não dispunham de canais permanentes de comunicação com a instituição e a oferta ágil de serviços não era prioridade. Quanto à política de pessoal, os critérios de competência e mérito não eram a base dos sistemas de seleção e avaliação do servidor.

3-A obsolescência da plataforma tecnológica não permitia a estruturação de informações para viabilizar o monitoramento dos resultados e dar suporte ao processo decisório. Os controles internos e externos eram excessivos e burocráticos, quase um fim em si mesmos.

Diante dessa realidade, o Banco começou a advogar a implantação de sistemas integrados de gestão administrativa e fiscal e o fortalecimento das áreas de planejamento, tecnologia e atendimento ao público, além do aperfeiçoamento dos processos normativos e operacionais, com a introdução de mecanismos de controle. 
As diretrizes defendidas pelo BID incluíam ainda a implantação de sistemas de metas e indicadores de desempenho e de programas permanentes de formação de servidores. Os projetos deveriam enfatizar os processos participativos internos e externos e melhorar a relação com a sociedade. Finalmente, o processo de transparência e controle social deveria permitir o acesso imediato e permanente do público às informações administrativas e fiscais.

Os programas convencionais de Reforma de Estado necessitavam, de acordo com o BID, de ampla reformulação para possibilitar a concretização de um dos seus principais objetivos: mudanças na cultura organizacional, a começar pelos valores e atitudes dos gestores. Houve avanços na maioria dos países que adotaram os programas, com a modernização da plataforma tecnológica e institucionalização de atividades de planejamento e capacitação de pessoal, instalação de centrais de atendimento ao cidadão e ampliação da oferta de serviços via Internet. No entanto, durante a avaliação desses projetos, foram identificados alguns pontos críticos a serem superados

A reforma do Estado deve assegurar que este seja cada vez mais efetivo, eficiente, eqüitativo e transparente. Uma mudança dessa natureza exige um amplo nível de consenso social, o que requer, por sua vez, a construção de uma visão de futuro, a ser discutida, compartilhada e comunicada. Desta maneira, um dos objetivos do programa é o de promover a participação e o controle do cidadão, além da responsabilidade compartilhada na gestão pública.

Em síntese, a modernização do setor público é um processo de transformação cultural das instituições. Consiste em passar de um estado burocrático - passivo, hierárquico e baseado em controles - para um estado flexível e dinâmico, cujo modelo de gestão esteja fundamentado na orientação para resultados, na capacitação e comprometimento dos servidores mediante um processo de planejamento participativo e no controle efetivo da sociedade, construído a partir de práticas de transparência, participação e prestação de contas. Todos os objetivos da modernização, relacionados com eficiência, eficácia e transparência, devem ser claramente definidos (CRUZ, 2001):

- Eficiência Operacional - Em busca deste objetivo, as ações apresentam-se focalizadas na geração e controle da informação, compreendendo o redesenho e automação de processos. Neste particular, identificam-se alguns pontos críticos a serem superados pelos gestores públicos:

- A existência de rede de equipamentos interligados amplia exponencialmente a demanda por novas tecnologias.

- A área de gestão da informação e da tecnologia geralmente não está suficientemente estruturada e capacitada para exercer seu papel estratégico.

- A implantação de sistemas informatizados implica a socialização da informação, 
podendo provocar o rompimento de "nichos de poder" consolidados graças ao monopólio dessa informação por grupos ou indivíduos.

- A força das novas tecnologias pode determinar o caminho a ser seguido pela instituição, inclusive quanto ao seu modelo de organização, gestão e funcionamento.

- Eficácia Gerencial - A busca de eficácia se dá com a introdução de novos métodos e instrumentos de gestão. Em geral o esforço para a concretização de uma gestão orientada para resultados apresenta-se fundamentado na formulação dos seguintes elementos comuns: a definição da missão e da visão de futuro da instituição; o estabelecimento de metas mensuráveis para cada unidade do órgão; a definição de indicadores de desempenho; a reestruturação organizacional, a formação de gestores e servidores e a implantação de sistemática de avaliação de pessoal. Os pontos críticos inerentes ao modelo de gestão por resultados incluem:

- Hostilidade de funcionários em relação à aplicação de indicadores. Por isso deve haver ampla discussão interna do assunto.

- O processo deve ser iniciado por um elenco reduzido de indicadores cuja implantação seja viável num primeiro momento, com o objetivo de aperfeiçoá-los e introduzir outros ao longo do tempo.

- A autonomia na gestão dos recursos humanos, materiais e financeiros pode ser restringida pela predominância do modelo burocrático de controle.

- Transparência e Controle Social - Esse objetivo está relacionado com o desenvolvimento da responsabilidade compartilhada, que pressupõe a valorização do cidadão e dos servidores. Estes devem ser envolvidos ativamente no processo através do planejamento participativo que aumenta o seu comprometimento com os resultados da instituição. A transparência e o controle social implicam a adoção dos seguintes procedimentos: Divulgação (a sociedade deve ser informada sobre a atuação do órgão em linguagem acessível, de forma ampla, estruturada e contínua); Prestação de Contas (o governo tem de abrir o diálogo com a sociedade, inclusive quanto aos insucessos, suas causas e propostas de ajustes); e Participação (a sociedade deve ser chamada a participar e assumir a responsabilidade compartilhada pela gestão pública, através de diversos mecanismos). Neste caso, os pontos críticos são os seguintes:

- A avaliação do nível de compromisso do servidor e do grau de transparência/controle social da gestão pública apenas pode ser confirmada através de pesquisa (aberta ou estruturada) realizada diretamente com os públicos interno e externo. As pesquisas devem ser executadas com independência e devem atender aos princípios da transparência (divulgação e prestação de contas). Por fim, devem estar associadas a ações corretivas dos desvios identificados. 
- O processo de transparência e responsabilidade compartilhada pode ser fortemente influenciado pelo modelo de gerenciamento de informação prevalecente na organização. Se há uma prática corrente de "esconder" informações consideradas estratégicas, é de se esperar que o processo de abertura seja lento e difícil. O trabalho deve ser iniciado mesmo assim, com o objetivo de se ampliar a quantidade e melhorar a qualidade das informações consideradas "publicáveis" ao longo do tempo.

口 Ética na Gestão Pública - A experiência do BID com a reforma do setor público na América Latina mostrou que os três objetivos já examinados não são suficientes para assegurar a mudança cultural proposta pelo processo de modernização, tornando imprescindível a incorporação de um quarto e grande objetivo - promover a ética na gestão pública. O sistema jurídico brasileiro é dotado de um conjunto bastante abrangente de leis, normas e regulamentos que estabelecem princípios éticos. Na Constituição Federal podem ser encontrados seis princípios fundamentais:

- Legalidade - a lei determina o que deve ser feito.

- Impessoalidade - a atividade administrativa deve ser exercida com neutralidade.

- Publicidade - os atos devem ser divulgados, isto é, o agente público deve atuar com transparência.

- Eficiência - os resultados de gestão devem ser úteis, eficazes, racionais e econômicos.

- Moralidade - a atividade pública deve ser exercida com probidade.

- Licitação - a igualdade, a impessoalidade e a moralidade devem ser garantidas no processo de aquisição de bens e serviços.

Essas normas costumam ser transgredidas tanto por ignorância ou inépcia como por cinismo. Assim, a reflexão ética cria as condições favoráveis para a recuperação de valores morais, consistentes com a cultura organizacional. O mundo começa a viver a "era da ética", em que os princípios éticos serão muito mais amplamente praticados e discutidos do que hoje. As instituições públicas deverão também caminhar nessa mesma direção, definindo claramente a aplicação dos princípios constitucionais acima citados ao conjunto de suas atividades e relacionamentos. Na visão do BID, a Comissão de Ética Pública do governo federal poderá ajudar a impulsionar esse esforço. 


\section{1-Definição do Problema de Pesquisa}

- Campo de Estudo: Administração Pública Municipal

- Assunto: Modernização Administrativa Municipal suportada pela TI

- Tema da Dissertação: Implementação de Projetos de Modernização Administrativa Municipal suportados pela TI

Pergunta-problema:

Quais os principais Fatores Facilitadores e Dificultadores percebidos na Implementação de Projetos de Modernização Administrativa Municipal suportados pela TI ?

Estudo dos casos das administrações municipais de Santo André e São Paulo. 


\section{2-Justificativa do Estudo}

A pesquisa se mostra atual, útil e relevante no sentido de sistematizar o conhecimento e entender com profundidade a dinâmica da Implementação de Projetos de Modernização Administrativa Municipal suportados pela TI, servindo de referencial importante para os gestores públicos e pesquisadores de uma alguma forma envolvidos com o tema.

No Brasil, a implementação de projetos de TI, a melhor estratégia para a disseminação do uso da Internet na função pública e a definição de qual é o papel do Estado neste campo vêm sendo objeto de crescente interesse e debate. Vários estudos indicam que tanto o governo federal quanto os governos subnacionais já estão consideravelmente envolvidos com a aplicação das novas tecnologias de informação na administração pública. Grandes dificuldades, porém persistem, o que dificulta se atingir estágios mais avançados de presença do governo na Internet, cuja superação depende de investimentos consideráveis na modernização administrativa da União, estados e municípios (Fernandes, 2001).

Os estudos acadêmicos a respeito do tema ainda são poucos e bastante restritos no Brasil, o que pode ser explicado pelo fato de ser uma realidade viável apenas recentemente no universo das Prefeituras, principalmente através da adesão a programas federais como o PMAT/BNDES.

Buscou-se na revisão bibliográfica sistematizar o conhecimento teórico relevante e através do modelo conceitual de pesquisa proposto, verificar e discutir as variáveis percebidas em cada unidade de análise, construindo um material de apoio-referência para os administradores públicos municipais envolvidos em processos similares e também subsidiar outras pesquisas na área da modernização da administração pública. 


\section{3-Objetivos}

Este trabalho apresenta uma pesquisa qualitativa e exploratória sobre o tema da implementação de projetos de modernização administrativa municipal suportados pela TI e tem como objetivo maior identificar os principais fatores facilitadores e dificultadores percebidos durante as implementações realizadas nas administrações financeiro-tributárias de municípios paulistas.

Busca-se também construir e validar um modelo conceitual de pesquisa para estudo de projetos de modernização da administração pública, com especial enfoque na realidade das prefeituras brasileiras, a partir de uma revisão bibliográfica que sistematiza e abrange os principais aspectos teóricos, para posteriormente conhecer e analisar as forças e fraquezas percebidas no processo, levantar e discutir as principais motivações e resultados alcançados pelos projetos-alvo nas cidades de São Paulo e Santo André.

Através da correta aplicação do método do estudo de caso, devidamente apoiada por um modelo conceitual de pesquisa, caminha-se de maneira estruturada para levantar e discutir a aderência dos resultados de campo com o referencial bibliográfico e ainda poder inferir, a partir de uma análise comparativa, semelhanças e diferenças na condução e nos resultados de cada projeto-alvo.

\section{Delimitação e viabilidade}

O escopo do trabalho é realizar um estudo qualitativo-exploratório para melhor entendimento dos facilitadores e das dificuldades e sistematizar o conhecimento referente ao processo de Implementação de Projetos de Modernização Administrativa Municipal suportados pela TI.

O trabalho se inicia com uma revisão bibliográfica que busca cobrir os principais aspectos teóricoconceituais do tema em questão e subsidiar a construção de um modelo conceitual de pesquisa utilizado para responder a pergunta-problema.

Pela natureza da investigação se optou pelo método do Estudo de Caso tendo como unidades de análise as administrações municipais de Santo André e São Paulo. Os dados da pesquisa foram coletados através de Entrevistas focadas realizadas pelo próprio pesquisador, complementadas por outras fontes de evidência como observação direta e documentação dos projetos. Através da aplicação de métodos e instrumentos de pesquisa adequados, pode-se inferir correspondências, ausências e novos elementos.

A pesquisa foi realizada diretamente nas unidades responsáveis pela administração financeirotributária do município de São Paulo, organização onde o pesquisador responsável exerce sua 
atividade profissional desde 1999, vivenciando intensamente todo o histórico de acontecimentos de interesse do estudo, além de conhecer e ter acesso a informações para tal. Foram coletados dados similares nos órgãos da administração financeiro-tributária da prefeitura de Santo André. Foram aplicados roteiros de entrevista para melhor coletar a percepção dos respondentes - planejadores e líderes de projeto - com posterior análise das semelhanças e diferenças nas implementações.

Parte-se de um conjunto inicial de pressupostos teórico-conceituais que serão comparados com a percepção coletada em campo, infere-se então elementos validados e não validados, além de novos fatores específicos do escopo do trabalho. Cabe ressaltar porém que as possibilidades de generalização e abrangência das conclusões da pesquisa são limitadas pela utilização do método do Estudo de Caso, conforme esclarecido no item Limitações da Pesquisa. 


\section{2-REFERENCIAL TEÓRICO}

A revisão bibliográfica está organizada em quatro tópicos que referenciam o escopo do trabalho de pesquisa, de modo a sustentar e viabilizar a resolução adequada da pergunta-problema e atingir plenamente os objetivos da dissertação. Busca-se sistematizar e explicitar o sistema teórico de modo a entender com profundidade os principais aspectos do tema, sustentados por bibliografia acadêmica relevante e atualizada (ver Figura 01).

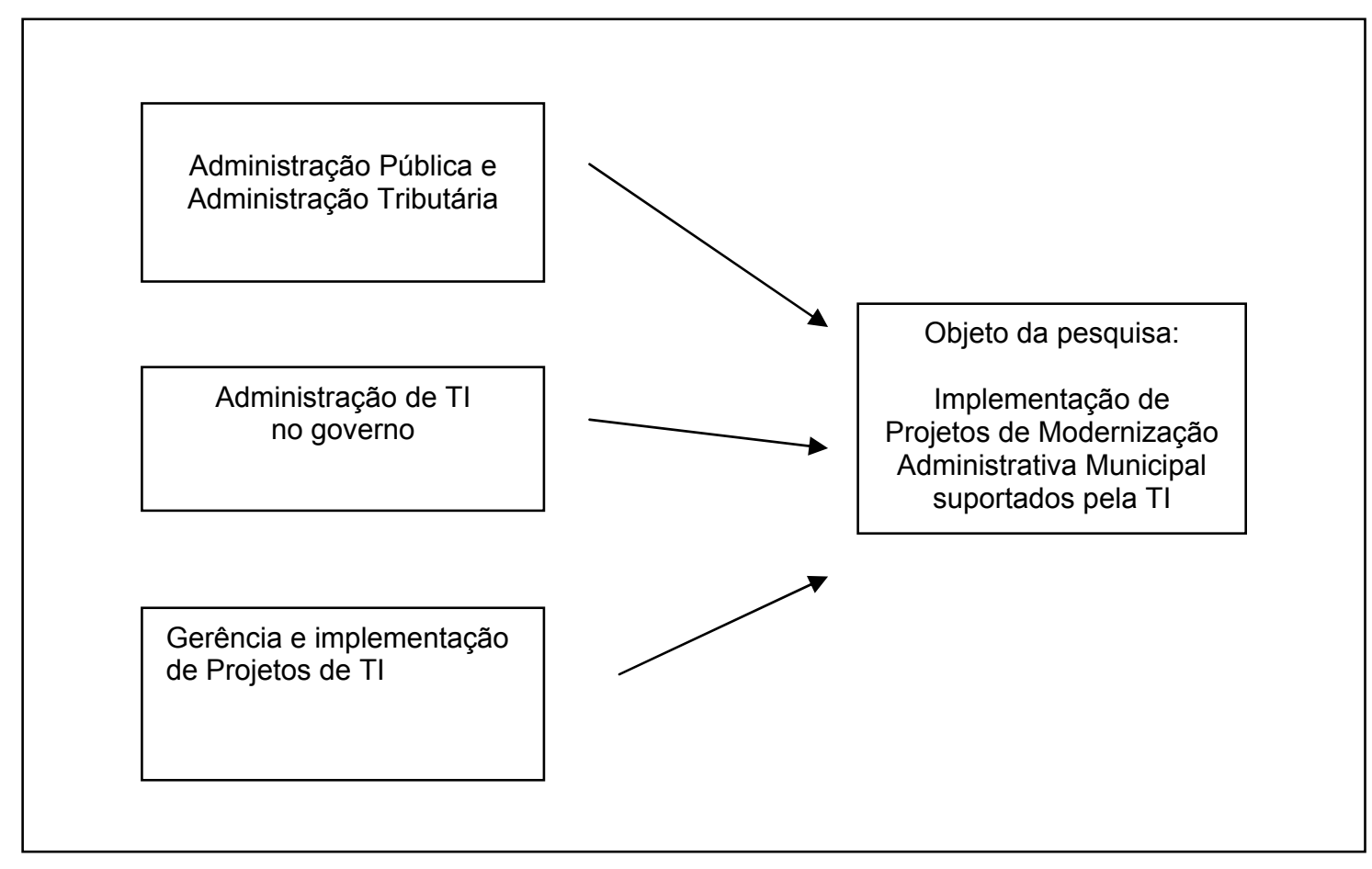

FIGURA 01 - Organização da revisão bibliográfica

Podemos definir como "fatores facilitadores e dificultadores percebidos" as situações e aspectos relatados conforme opinião dos respondentes das Entrevistas. Classifica-se esses fatores em dois agrupamentos antagônicos: fatores propulsores e fatores inibidores percebidos no processo de implementação. Serão coletadas outras fontes de evidências além da entrevista focada, entre elas a observação de campo e a análise de conteúdo de documentos internos das organizações.

Os esforços organizacionais para a assimilação e utilização de TI são realizados na forma de projetos de TI. Essa resposta à necessidade da instituição apresenta características que englobam a exigência de um objetivo predeterminado, com qualidade, prazo, orçamento, condições ambientais e satisfação dos envolvidos, incertezas, complexidades e urgências (Albertin, 2001).

Conforme Kerzner (1995) os projetos possuem como característica essencial serem temporários e únicos, ou em outras palavras, eles são finitos e regulares, visando ao desenvolvimento de um novo 
produto ou serviço. A administração desse esforço organizacional é denominada de gerência de projetos.

A execução é o processo básico de realização do plano do projeto - pois é nele que a grande maioria do orçamento do projeto será gasta. Neste processo, o gerente e a equipe de gerência do projeto devem coordenar e direcionar as diversas interfaces técnicas e organizacionais do projeto. Além disto, é o processo mais diretamente afetado pela área de aplicação do projeto, pois é exatamente nele que o produto do projeto é criado (PMBOK, 2000).

Toda empresa toca projetos, o que as diferencia é a eficiência com que executam esta tarefas e o índice de sucesso de seus projetos. Implantar gerenciamento de projetos é um processo de amadurecimento. Assim, é necessário traçar uma estratégia na qual se vai agregando conhecimentos que serão experimentados, testados e praticados, gerando o amadurecimento. O sucesso de implantação de gerenciamento de projetos em uma organização está relacionado com o atingimento dos objetivos esperados pela alta administração.

Os aspectos de implementação de tecnologia em uma organização podem ser resumidos em três categorias principais: o alinhamento estratégico, a adaptação da organização e a adaptação da área de TI Interna (Albertin, 2000).

Segundo Turban, Mclean e Wetherbe (1999), a TI é a catalisadora das mudanças fundamentais na estrutura, nas operações e no gerenciamento das organizações. A TI revolucionou a forma de realizar negócios, mas o negócio em si está apenas se adaptando vagarosamente às novas possibilidades. A tecnologia necessária está disponível e aguardando, mas o processo de conversão levará algum tempo para ser completado (Amor, 2000).

\section{Modernização Administrativa Municipal e "governo eletrônico"}

O Governo Federal tem participado de ações voltadas para a reforma do Estado, através do BNDES, tendo como instrumento o PMAT. O PMAT é composto por uma série de ações que buscam dotar uma Prefeitura de ferramentas modernas de administração de seus recursos (tributários, humanos, financeiros e materiais ) e de tomada de decisão, orientados pelos critérios da descentralização administrativa e da transparência nas ações do Poder Público.

A modernização deve ser acompanhada do fortalecimento da capacidade gerencial, normativa, operacional e tecnológica da administração tributária e da gestão pública dos serviços sociais básicos e demais ações da natureza fiscal, além do monitoramento e controle público dos gastos da Prefeitura, resgatando a credibilidade do Poder Público quanto ao cumprimento de suas obrigações. 
O conceito usual de "Governo Eletrônico" foi concisamente elaborado por Gartner Group apud Santos (2002): O "Governo Eletrônico" seria a contínua otimização de oferta de serviço, participação do eleitorado e governaça mediante transformação de relacionamentos internos e externos com uso da tecnologia, da internet e da nova mídia.

Assim, esta definição amigável significa, o mais proximamente da realidade, longe, pois, das utopias, que "Governo Eletrônico" é o uso da TI para promover maior eficiência e maior efetividade governamental, facilitando o acesso aos serviços públicos, permitindo ao grande público o acesso à informação, e tornando o governo mais transparente para o cidadão. Porém, o "Governo Eletrônico" não é um atalho para o desenvolvimento econômico, o salvamento orçamentário ou a eficiência governamental. O "Governo Eletrônico" não é o Big-Bang, um único evento que imediatamente e para sempre altera o universo do governo. O "Governo Eletrônico" é um processo - chamado evolução - e também um grande esforço que apresenta custos e riscos financeiros e políticos. Esse risco pode ser significativo. Se não forem bem conceituadas e implementadas, as iniciativas de "Governo Eletrônico" podem desperdiçar recursos, falhar em sua promessa de entrega útil de serviços e, assim, aumentar a frustração com a administração pública por parte do cidadão. Particularmente nos países em desenvolvimento, os recursos são escassos, de modo que o "Governo Eletrônico" pode ter como alvo áreas com alta chance para sucesso e produzir ganhos. Além disso, o "Governo Eletrônico" nos países em desenvolvimento pode acomodar certas condições únicas, necessidades e obstáculos (Santos, 2002).

Usando o conceito de Zweers \& Planqué (2001), pode-se dizer que: "Governo Eletrônico" é um conceito emergente que objetiva fornecer ou tornar disponível informações, serviços ou produtos, através de meio eletrônico, a partir ou através de orgãos públicos, a qualquer momento, local e cidadão, de modo a agregar valor a todos os "stakeholders" envolvidos com a esfera pública.

Já Balutis (1999), define "Governo Eletrônico" através da seguinte equação: "Governo Eletrônico" = "Comércio Eletrônico" + "Customer Relationship Management" (CRM) + "Supply Chain Management" (SCM) + Gestão do Conhecimento + "Business Intelligence" (BI) + Tecnologias Colaborativas.

Segundo Lenk \& Traunmüller (2001), quatro perspectivas podem ser, hoje, vislumbradas, acerca de "Governo Eletrônico", quais sejam:

1. A Perspectiva do Cidadão - visando oferecer serviços de utilidade pública ao cidadão contribuinte;

2. A Perspectiva de Processos - visando repensar o "modus-operandi" dos processos 
produtivos ora existentes no Governo, em suas várias esferas, tais como, por exemplo, os processos de licitação para compras ("e-procurement");

3. A Perspectiva da Cooperação_- visando integrar os vários órgãos governamentais, e estes com outras organizações privadas e não-governamentais, de modo a o processo decisório possa ser agilizado, sem perda de qualidade, assim como evitando-se fragmentação, redundâncias etc. hoje existentes nas relações entre esses vários atores;

4. A Perspectiva da Gestão do Conhecimento - visando permitir ao Governo, em suas várias esferas, criar, gerenciar e disponibilizar em repositórios adequados, o conhecimento tanto gerado quanto acumulado por seus vários órgãos.

Essas quatro facetas podem ser melhor visualizadas na Figura 02 a seguir:

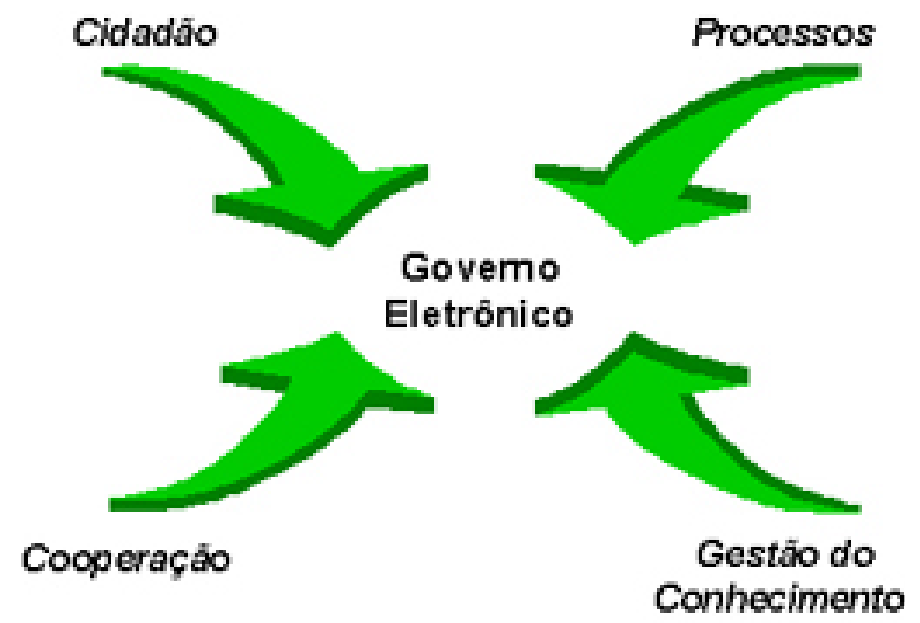

FIGURA 02 - Quatro perspectivas do governo digital (Lenk \& Traunmüller, 2001)

Adicionalmente, "Governo Eletrônico" também pode ser entendido através de outras taxonomias, tal qual a expressa por Perri 6 (2001), onde "Governo Eletrônico" pode ser entendido através dos três seguintes vieses:

1. Fornecimento de Serviços Eletrônicos - Atualmente, a maior parte dos esforços, recursos e atenção política devotados a "Governo Eletrônico" se concentram nessa área. Essa área envolve o fornecimento de serviços de utilidade pública para o contribuinte, assim como o relacionamento governo-empresas, usando a TI como propiciadora para tal.

2. Democracia Eletrônica - Novas legislaturas, como as da Escócia e País de Gales, estão usando sistemas de votação eletrônica nos seus Parlamentos Locais, assim como há no mundo experiências piloto de consulta "on-line" aos cidadãos. O Brasil vem usando o voto em urnas eletrônicas - não sem controvérsias acerca da segurança da votação - já há algum tempo, o que o enquadraria nessa tipologia.

3. Governo via Internet - Segundo Kraemer \& Dedrick (1997), essa é a área menos estudada 
de "Governo Eletrônico". Ela incluiria, entre outras atividades, todo o suporte digital para elaboração de políticas públicas; tomada de decisões; "public choices" e "workgroup" entre os vários gestores públicos de diferentes escalões.

Como se pode observar na Figura 03, várias definições estão, hoje, associadas ao termo "Governo Eletrônico"

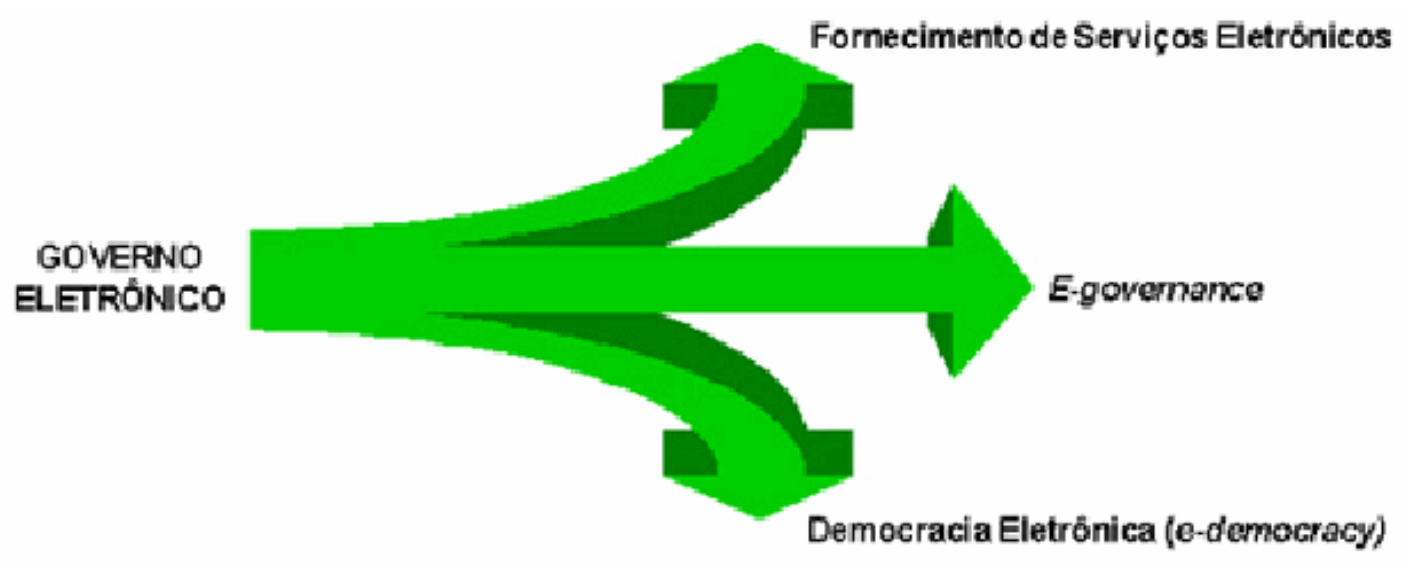

FIGURA 03 - Taxonomias para "Governo Eletrônico"

O "Governo Eletrônico" é reconhecido mediante formas, tipos de relacionamento e estágio de integração pelos quais se manifesta. As formas de "Governo Eletrônico", algumas das quais comentadas no capítulo dois deste ensaio, são a manifestação mais explícita, porque concretizam os diferentes tipos de relacionamento que o"Governo Eletrônico" engendra, indo de um simples centro de atendimento ao cidadão ("callcenter"), passando por um portal corporativo governamental ("workplace") até um quiosque de auto-atendimento. 


\section{1-Administração pública e administração tributária}

Este primeiro capítulo da revisão bibliográfica busca definir e apresentar elementos que compõem o contexto da moderna administração pública brasileira, com especial atenção para a administração pública focada no cidadão e ainda, relatar a conjuntura das organizações responsáveis pela administração tributária municipal.

A conjuntura da administração pública no mundo

Representantes de governos de diversos países, agências multilaterais, empresas privadas e organizações não governamentais reuniram-se no II Fórum Global para debater o Estado democrático e a governança no século XXI. Os debates foram marcados pela riqueza de experiências, diversidade de perspectivas e pluralidade de abordagens sobre o tema. Não obstante, há pontos de convergência que permitem a construção de uma Agenda que contém temas para ações na direção de um Estado democrático e de uma governança voltada ao bem estar dos cidadãos.

Há um reconhecimento de motivações comuns às diversas experiências já realizadas de reforma do Estado:

- Inadequação do papel do Estado e do desenho do setor público diante dos cenários, em constante mutação, de globalização, desenvolvimento tecnológico e reestruturação produtiva.

- Crise fiscal associada ao déficit público, à dívida externa e ao desempenho insatisfatório das empresas públicas.

- Padrões de demanda mais exigentes e complexos por parte dos cidadãos.

- Efeitos perversos da ação do Estado causados pelo patrimonialismo, pelo clientelismo e pela corrupção.

- Reconhecimento de que a esfera pública não se limita à esfera estatal, incluindo as ações de cunho público promovidas pela sociedade civil.

- Provisão inapropriada de serviços pelo sistema de proteção social - envolvendo tanto a exclusão de segmentos expressivos da população quanto a inadequação dos serviços prestados.

Estas motivações conduziram a reformas de caráter fortemente minimalista, com ênfase na eficiência econômica e administrativa, superestimando a capacidade de as instituições democráticas processarem o debate valorativo. $\mathrm{O}$ não enfrentamento destes desafios tende a gerar uma "fadiga cívica" que ameaça a perenização e a radicalização da democracia.

Ao longo do debate no Fórum, emergiram eixos e princípios de uma agenda para o Estado 
democrático e a governança no século XXI:

- O Estado necessário é um Estado capaz de atuar de forma proativa na reconstrução institucional da sociedade. A governança não se limita às fronteiras do Estado, mas implica o desenvolvimento de canais cooperativos com o mercado e com a sociedade civil.

- É necessária uma revalorização da política, estabelecida através do debate valorativo sobre os fins (bem estar) com o conjunto de atores sociais, de modo a se recuperar a credibilidade dos governos, da administração pública e das instituições democráticas.

- A busca da boa governança requer uma abordagem holística, no sentido de que a reforma do Estado não deve se restringir ao Poder Executivo, devendo abranger os Poderes Legislativo e Judiciário.

- A governança requer o estabelecimento de alianças, coalizões, parcerias e redes que envolvam o mercado, a sociedade civil, diferentes níveis de governo e a cooperação internacional.

- Parcerias podem relacionar-se a qualquer função ou atividade estatal sem, contudo, significar retração ou recuo na responsabilidade do Estado.

- A descentralização deve se dar mediante formas política, institucional e fiscalmente sustentáveis.

- Deve ser buscada a responsabilidade fiscal dos decisores públicos.

- Há necessidade de um projeto de longo prazo sem a falsa dicotomia entre universalismo e focalização.

O reconhecimento da necessidade de coalizão para a governança demanda o desenvolvimento da capacidade institucional do Estado para a sua atuação como coordenador e animador dessas alianças. O desenvolvimento da capacidade do Estado exige um modelo de gestão pública com as seguintes características:

- Fortalecimento da função pública e profissionalização dos servidores.

- Adequação da arquitetura organizacional do Estado: "rightsizing" com ênfase na função reguladora e no aprimoramento da prestação de serviços universais associados aos direitos de cidadania.

- Foco em resultados, mediante avaliação permanente, de modo a possibilitar o controle estratégico das políticas públicas.

- Preocupação com eficiência, custos e responsabilização no uso dos recursos.

- Orientação para o cidadão-usuário.

- Simplificação de procedimentos, regulações e legislação.

- Ampliação da autonomia de gestão dos agentes públicos mediante o estabelecimento de relações contratuais baseadas em resultados e requisitos de transparência.

- Transparência nas ações e decisões, assim como acessibilidade plena às informações públicas, 
possibilitando o desenvolvimento de mecanismos de controle social.

- Desenvolvimento de arranjos institucionais inovadores envolvendo diversos atores para representação de interesses, prestação de serviços, regulação cooperativa e controle social.

O Fórum destacou, finalmente, a importância da definição de finalidades que orientem a reforma. Não basta propor uma engenharia institucional e mecanismos novos de gestão (como o Estado deve ser e como deve atuar). Também a idéia de que os efeitos macroeconômicos das reformas são evidentes o custo da reforma é menor que o custo de não reformar - não é suficiente. É preciso discutir e debater que projetos substantivos nortearão a ação estatal. Dentre as questões substantivas foram enfatizadas o combate à corrupção, a erradicação da pobreza, a redução da desigualdade com ênfase na TI, a promoção da coesão social e o desenvolvimento econômico.

Para estudar o uso da TI num contexto de transformação do Estado, conta-se com os objetivos estratégicos genéricos de Reforma descritos em Heeks e Davies (1999) acrescido de "democratização", pela importância dada ao tema por alguns dos governos no país. Os objetivos estratégicos são: eficiência, descentralização, transparência, melhoria na gestão de recursos, adoção de práticas de gestão de mercado e democratização.

Para Heeks e Davies (1999), há quatro abordagens possíveis para a condução de iniciativas de Reforma na Sociedade Informacional: ignorar a TI, isolá-la da formulação de iniciativas de reforma, idolatrá-la e por fim integrá-la ao processo de mudança do governo. É uma simplificação considerável da realidade, reconhecida pelos autores, com diferenças de abordagens dentro do mesmo país e de uma instituição para outra. Mas foi construída baseada na observação de casos reais e é útil para a caracterização do emprego da tecnologia e do papel dos dirigentes públicos de tecnologia na dinâmica da transformação do governo.

Heeks e Davies (1999) apresentam como bastante promissora a integração da TI nos processos de Reforma. Os dirigentes públicos tornaram-se conhecedores da informação e reconhecem a informação como um recurso organizacional que é central a todas as funções de governo. A tecnologia é relegada a um papel secundário: é vista como um meio valioso de atingir alguns dos objetivos da reforma, não um fim em si mesma. A reengenharia de sistemas e TI agora estão completamente integradas ao processo de mudança organizacional.

\section{A Administração tributária municipal}

Não se pode pretender discutir um tema vinculado aos tributos municipais, sem a apresentação de conceitos essenciais fundados na Constituição Federal (CF). Art.18 - A organização políticoadministrativa compreende a autonomia da União, dos Estados, dos Municípios e do Distrito Federal. 
Pela autonomia, não há supremacia de um ente federado sobre o outro. Todos são iguais e independentes, no referente às respectivas áreas de atuação outorgadas pela Constituição. A autonomia municipal, dentre outros enfoques (como o político e o administrativo), é assegurada pela competência privativa para a instituição de seus tributos e a aplicação de suas rendas, de maneira a permitir o cumprimento de suas competências. $\mathrm{O}$ equilíbrio entre os encargos e as receitas está na essência da autonomia e é ele que vai garanti-la. Arts. 22 a 25 - Esses dispositivos estabelecem as competências administrativas das entidades federativas e o conteúdo do art. 30 volta-se para as competências municipais. São as atribuições dos encargos locais.

A execução dessas atividades, desses encargos, necessariamente vão gerar despesas. Para atender às despesas, a Constituição arrola várias fontes de recursos, discriminando-as a cada ente federado, o que se denomina discriminação de rendas. Essa outorga de competência tributária é feita relacionando os fatos econômicos, que darão fundamento para a criação dos tributos pelos respectivos Poderes Legislativos. São as receitas próprias de cada ente federado.

Os tributos que compõem as receitas próprias dos municípios são especificados pelos artigos 145 e 149. O Art. 145 - Afirma que os tributos são:

I - os impostos - especificando os municipais no art. 156, os federais nos arts. 153 e 154 e os estaduais no art. 155;

II - as taxas - as taxas de polícia pelo exercício do poder de polícia e as taxas de serviços pela utilização de serviço público, específico e divisível, prestado ao contribuinte ou colocado à sua disposição;

III - a contribuição de melhoria - decorrente de obra pública.

Por várias razões de cunho econômico e político, as receitas próprias não são suficientes para atender aos encargos, embora se deva enfatizar serem as mais importantes, pois sobre elas os municípios têm o seu governo, podendo criá-las, diminuí-las, isentá-las, remiti-las, anistiá-las, etc.

Sabendo desse efeito, o Legislador Constituinte criou o sistema de transferências e participações, com a finalidade de ensejar um acréscimo financeiro às rendas locais, recebendo os municípios parte das arrecadações dos recursos de determinados impostos estaduais e federais. As que mais se sobressaem são as provenientes das receitas do Imposto sobre Circulação de Mercadorias (ICMS) e do Fundo de Participação dos Municípios, formadas pelas arrecadações dos Impostos sobre a Renda e sobre Produtos Industrializados.

Como a competência tributária pertence a outro ente federado, os municípios não têm qualquer 
ingerência em sua instituição e cobrança, sobrando-lhe apenas a conduta passiva de receber sua parte. Todavia, em face dessa situação e agregada à facilidade política e econômica, passou a ocorrer um infausto fenômeno decorrente da conduta da maior parte das municipalidades.

O que se pretendia era conceder aos entes locais um acréscimo às suas rendas, porém, na prática, o que ocorreu foi a transformação das receitas transferidas em mera substituição das receitas próprias, visto que uma grande parte dos entes locais passou a viver praticamente daqueles recursos, negligenciando ou até mesmo deixando de cobrar as receitas próprias. O advento da Lei de Responsabilidade Fiscal, que exige a efetiva arrecadação dos tributos municipais, altera sobremaneira esta situação, aliás, em benefício dos próprios municípios.

As receitas próprias municipais são compostas dos seguintes tributos:

口 os impostos: IPTU, Imposto sobre Serviços (ISS) e Imposto sobre Transmissão de Bens Imóveis Intervivos (ITBI);

- as taxas de polícia e de serviço, que variarão conforme a municipalidade;

a a contribuição de melhoria.

Dentre esses tributos, destaca-se, em função de suas características e por ser um dos mais antigos, o Imposto Predial e Territorial Urbano (IPTU), que é elevado à principal fonte dos recursos. Como a própria denominação indica, o imposto incide sobre a propriedade predial e territorial urbana, onerando assim os proprietários dos terrenos e das edificações situados no território municipal.

A tributação da propriedade volta-se às primeiras incidências fiscais do País, sendo, destarte, praticamente a mais antiga. Isto torna o IPTU muito importante, pois é sabido que quanto mais antigo o imposto mais solidificados estão sua estrutura e seus efeitos. Não só pela sua tradição, mas especialmente pela facilidade de sua fiscalização e cobrança, esse imposto fornece uma importante arrecadação. Além do mais, cabe frisar o fato de que, em incidindo sobre o bem imóvel, em princípio, sua satisfação está garantida, vez que o mesmo sempre responderá pelo pagamento do respectivo crédito tributário.

Serve como exemplo contrário o ISS. É um imposto dinâmico, pois basta o contribuinte resolver alterar o local de sua atividade para outro município que sua receita será perdida. É justamente esta razão que promove a guerra fiscal municipal, baseando-se em incentivos fiscais oferecidos, como, por exemplo, a redução de alíquotas, isenções, redução de base de cálculo, etc. Durante toda a vida do IPTU foi ele, e deverá continuar sendo, a maior fonte de receita municipal, salvo raríssimas exceções, quando é suplantado pelo ISS. Durante o período inflacionário, sua arrecadação foi duramente atingida por questões financeiras e políticas, fenômeno este voltado à sua base de cálculo, o valor 
venal dos imóveis.

Segundo Afonso e outros (1998), a expectativa é que os investimentos públicos devem priorizar; antes de tudo a modernização da gerência fiscal dos diferentes governos; em especial dos municipais; uma vez que tendem a se tornar os agentes públicos por excelência executores dos programas sociais básicos. Fomentar a modernização da administração tributária é apenas um primeiro; embora crucial; passo. O município brasileiro está mudando; muito e para melhor. Talvez o que não esteja mudando; ao mesmo tempo e tanto; é a percepção de quem; de cima e de longe; ainda os vêem como presos aos velhos tabus.

Reconhecendo a enorme dificuldade que enfrentam as administrações municipais para realizarem investimentos voltados para o aprimoramento dos instrumentos de arrecadação de receitas próprias para o controle e gerenciamento da execução do gasto público e, ainda, para o aperfeiçoamento dos sistemas de informação voltados para o atendimento do cidadão em geral e, em particular, para o cumprimento das competências estabelecidas no âmbito do Sistema Único de Saúde (SUS), Estatuto da Criança e do Adolescente (ECA) e da Lei de Diretrizes de Bases da Educação (LDB), o governo federal vem anunciando a ampliação dos recursos colocados à disposição do BNDES, mais especificamente para o Programa de Modernização da Administração Tributária e da Gestão dos Setores Sociais Básicos.

Esse programa destina-se a financiar os investimentos necessários à modernização da administração tributária e à melhoria da qualidade do gasto público, dentro de uma perspectiva de desenvolvimento local e sustentado, visando proporcionar aos municípios brasileiros possibilidades de atuar na obtenção de recursos estáveis e não-inflacionários e na melhoria da qualidade e redução do custo praticado na prestação de serviços nas áreas de administração geral, assistência à criança e jovens, saúde, educação e de geração de oportunidades de trabalho e renda.

Dentre as ações financiáveis destacam-se as voltadas para:

- fortalecimento das capacidades gerencial, normativa, operacional e tecnológica da administração tributária e demais ações de natureza fiscal ou racionalizadoras do uso dos recursos públicos;

- aprimoramento da gestão pública dos serviços sociais básicos e aperfeiçoamento dos sistemas de informação, serviços e processos voltados para o cumprimento das competências municipais relativas ao SUS, ECA e LDB;

- a informatização, inclusive aquisição e desenvolvimento de software;

口 a capacitação, treinamento e aperfeiçoamento gerencial, técnico e de apoio operacional;

- a realização de serviços e estudos de natureza organizacional, administração de recursos 
humanos e de serviços gerais, gestão de fundos públicos, gerenciamento de licitações, contratos, processos administrativos, controle e cobrança de dívida pública, entre outros.

As opções de financiamento disponíveis para que os municípios invistam na modernização de seus processos:

PMAT. Os financiamentos até 2 milhões de reais são feitos pelo Banco do Brasil. Valores acima disso são feitos diretamente, pelo BNDES. Cada município pode requerer 18 reais por habitante ou $7 \%$ da receita líquida real. O prazo para aplicação do recurso obtido é de dois anos e o município tem mais seis para pagar a dívida. Os limites máximos para a aplicação, por setor, são $35 \%$ em TI e equipamentos de informática, $25 \%$ em capacitação de recursos humanos, $35 \%$ em serviços técnicos especializados, $25 \%$ em equipamentos de apoio à operação e fiscalização e $20 \%$ em infra-estrutura física.

PNAF-M - Programa Nacional de Apoio à Gestão Administrativa e Fiscal dos Municípios Brasileiros. Gerido pelo Ministério da Fazenda, tem 2,2 bilhões de dólares de verbas a serem aplicadas, sendo metade proveniente do BID. O financiamento máximo é de 18,5 milhões de dólares e os municípios têm quatro anos para aplicar o recurso e mais 16 para pagar. Os juros variam com a taxa cambial e custo de captação do BID. Assim como o PMAT, tem taxas máximas para aplicação nas seguintes áreas: capacitação, serviços técnicos, TI, material de apoio, infra-estrutura física.

O PMAT gerido pelo BNDES, foi lançado em setembro de 1997 e concebido com o objetivo de aumentar o nível de eficiência fiscal dos municípios; garantindo-lhes um fluxo adicional de recursos estáveis e não-inflacionários para o financiamento das despesas e investimentos locais. São os seguintes seus itens apoiáveis: TI e equipamentos de informática; capacitação de recursos humanos; serviços técnicos especializados; equipamentos de apoio à fiscalização e infra-estrutura física. Os focos de ação dividem-se em gerais (sistemas; legislação) e os específicos da administração tributária (cadastro; cobrança; fiscalização; estudos e atendimento ao contribuinte) e da administração financeira e patrimonial (orçamento; contabilidade e auditoria).

A análise da carteira do PMAT revela que; regra geral; os municípios que já possuem um padrão razoável de arrecadação tributária tendem a investir mais em informatização; treinamento de funcionários e recadastramento de contribuintes; com ênfase na racionalização e modernização dos procedimentos administrativos já existentes. É marcante a preocupação em melhorar o atendimento aos contribuintes; desde o treinamento de servidores e a montagem de postos descentralizados de serviços até a consolidação e maior divulgação da legislação tributária local. O que mais chama a atenção é o retorno dos projetos: em uma amostra de 20 municípios; o acréscimo esperado de receita; 
em um prazo de aproximadamente quatro anos; não é inferior a $20 \%$ e; em alguns casos; chega a superar os $60 \%$ (Afonso e outros, 1998)

A partir da implementação do PMAT; espera-se que as receitas com maior incremento imediato sejam aquelas referentes à propriedade (IPTU) e à transferência de imóveis (ITBI) que apresentam uma grande inadimplência; com a implantação de ações que melhorem a confiabilidade e o gerenciamento do cadastro de imóveis.

Os cadastros mobiliário e imobiliário; por vezes gerados há muito tempo; além de não possuírem qualquer mecanismo de integração; têm informações e modelos desatualizados; com dados insuficientes para elaboração de estratégias que orientem a ação fiscalizadora e o correto lançamento dos tributos. Os cadastros imobiliários; na maioria dos municípios; ainda se encontram em arquivos manuais; não integrados e incompletos quanto às novas áreas recentemente urbanizadas. Soma-se isto a fiscalização com equipes reduzidas; sobrecarregadas por serviços burocráticos; sem treinamento e com pouca mobilidade devido à carência de transportes.

A cobrança do IPTU e; vinculado a este; do ITBI; em face do elevado grau de inadimplência; constitui o componente que demanda investimento de maior vulto no curto prazo; devido à necessidade de remontagem ou atualização do cadastro de contribuintes; com detalhado trabalho de campo.

Conforme estudos relatados no site do BNDES, tem-se o seguinte contexto para a administração tributária municipal no Brasil:

- $\mathrm{Na}$ atualidade, cresce o entendimento de que é preciso aperfeiçoar/aprofundar a transferência aos municípios de gastos sociais básicos e que os mesmos não poderão ser financiados pelo aumento da participação local nos impostos federais e estaduais.

- É necessário promover uma verdadeira revolução no dia-a-dia da gestão pública através da modernização da gerência fiscal e com isso: elevar a receita própria e contribuir para a redução do endividamento e déficit públicos, bem como para o aumento do controle social do Estado brasileiro.

- A grande dispersão entre as cargas tributárias de municípios com PIB "per capita" semelhante revela um potencial tributário não explorado.

Os municípios com razoável padrão de arrecadação tendem a investir mais em informatização, treinamento de funcionários e recadastramento de contribuintes, com ênfase na racionalização e modernização dos procedimentos administrativos já existentes. 
A despeito da diversidade de situações individuais, a análise da evolução, dimensão e estrutura da arrecadação do agregado de municípios e dos esforços para modernização de suas administrações aponta para um cenário positivo e promissor.

Tende a ser cada vez mais coisa do passado a idéia de que municípios não se interessam por investir na modernização tributária e fiscal, não querem participar de um processo ordenado de transferência de encargos e, acima de tudo, não procuram contribuir para o ajuste fiscal do país.

Hoje, as prefeituras, em sua grande maioria, ainda que de modo muito diferenciado, estão implementando ações que busquem a ampliação da sua base tributária, a melhoria dos lançamentos dos tributos, da ação fiscalizadora e da relação fisco-contribuinte, a cobrança mais eficiente de débitos em atraso, entre inúmeras ações voltadas para o acompanhamento regular do cumprimento das obrigações tributárias. Os municípios estão mudando, muito e para melhor. Talvez o que não esteja mudando, ao mesmo tempo e tanto, é a percepção de quem, de cima e de longe, ainda os vêem como presos aos velhos tabus.

Conforme trabalho de Marchant e Martinelli (2000), toda tecnologia envolvida pela Internet traz maior rapidez na consecução dos serviços e mais facilidades para o contribuinte, que não necessita mais se deslocar para órgãos públicos a fim de conseguir o mesmo serviço que é prestado na tela de seu computador.

E não é somente o contribuinte que sai beneficiado pela prestação dos serviço pelo computador. Os órgãos governamentais que está oferecendo serviços na Internet também vêm auferindo melhores resultados com a nova forma de tecnologia empregada. Como prova disso, verifica-se que nos Estados da federação em que existe uma maior variedade de serviços ofertados, a arrecadação dos tributos estaduais tem aumentado consideravelmente, o número de funcionários envolvidos para o acompanhamento da efetivação das operações é muito inferior ao do que era utilizado para atendimento direto e, finalmente, o controle sobre o sujeito passivo da obrigação tributária tem sido ampliado e exercido de maneira muito mais efetiva.

Outro resultado decorrente da maior aplicação da tecnologia é a redução, de forma significativa, do custo necessário para a efetivação das operações, graças à redução de postos de atendimento e funcionários envolvidos na fiscalização, trazendo assim, economia aos entes tributantes. Como exemplo concreto disso, pode-se citar a Secretaria da Fazenda do Estado de SP, que reduziu o número de Postos Fiscais de atendimento em 20\% e dos funcionários envolvidos na contabilidade em 90\%, diminuindo drasticamente os custos de manutenção das repartições públicas e de impressão de formulários, além de deslocar o efetivo da mão-de-obra para outras atividades, de modo a otimizar os 
serviços oferecidos diretamente à população. Além disso, o aumento da arrecadação é patente. No caso, por exemplo, sobre a propriedade de veículos automotores - IPVA, a arrecadação passou de 443 milhões de reais em 1995 para 2,1 bilhões no ano 2000, um crescimento de espantosos 474\% (Marchant e Martinelli, 2000).

E ainda, ao contrário do que se imagina, a resistência interna à informatização dos serviços públicos não tem sido tão grande quanto se esperava, uma vez que os funcionários envolvidos nos serviços informatizados são deslocados para outras áreas. Utilizando o exemplo paulista mais uma vez, tem-se que os funcionários que exerciam cargos na contabilidade, exercem agora funções de analista de informações em áreas de controle. Isso quer dizer que, além de obter maiores recursos com o aumento da arrecadação, o Fisco exerce uma fiscalização mais eficaz, tanto pelo fato dos instrumentos tecnológicos possibilitarem uma conferência mais rápida e mais confiável dos dados, como também pelo deslocamento dos funcionários excedentes para outras atividades, os quais por sua vez diminuem os serviços burocráticos dos auditores fiscais, fazendo com que estes exerçam seu papel de maneira mais efetiva, visitando um maior número de empresas.

Marchant e Martinelli (2000), afirmam que as facilidades oferecidas aos contribuintes pelos órgãos governamentais pela Internet vêm crescendo nestes últimos anos, tendo proporcionado aumento da arrecadação e melhoria dos serviços prestados. Outro aspecto importante se refere ao fato de que, ao mesmo tempo em que a prestação de serviços pela Internet aproxima a Administração Pública dos cidadãos, na medida em que oferece melhores e mais eficazes serviços, ela oferece também maiores subsídios aos seus próprios funcionários, através da uniformização e padronização dos serviços prestados, além da disponibilização de dados, os quais muitas vezes só eram acessíveis aos órgãos localizados no grandes centros.

A disponibilização pelos órgãos governamentais de serviços eletrônicos via Internet significa uma maneira de se atingir a justiça social, uma vez que diminui custos da organização, oferece serviços melhores e mais eficientes, e ainda, auxilia no controle da arrecadação tributária.

Pesquisa do Instituto Brasileiro de Geografia e Estatística (IBGE) indica que apenas 5\% das prefeituras brasileiras não têm suas folhas de pagamento automatizadas, mas só $24 \%$ delas possuem e-mail. Estes dados demonstram que os municípios preocuparam-se com seus processos internos. Em vez de focar o investimento em "sites" e serviços "on-line" aos cidadãos muitos optaram por arrumar a cozinha, para garantir aumento na geração de receitas, economias nos processos e transparência. E parecem ter tomado uma decisão acertada, afinal, mesmo sendo menos perceptível para os moradores, a mudança conduzida dessa forma tende a ser mais consistente no médio prazo. 
Por trás da evolução das prefeituras na informatização de suas atividades estão pelo menos dois agentes financiadores: o BNDES e o Ministério da Fazenda. O primeiro é o responsável pelo PMAT, enquanto que o governo federal, ao lado do BID, protagoniza o PNAF-M (Programa Nacional de Apoio à Gestão Administrativa e Fiscal dos Municípios Brasileiros).

Ambos nasceram voltados a financiar os municípios na automatização dos processos tributários, com vistas a aumentar a geração de receita das prefeituras e torná-las mais independentes de verbas estaduais e federais. O raciocínio é simples: com os processos tributários informatizados, os municípios gastam menos com atividades cotidianas e corrigem falhas que aumentam a arrecadação, como valores de imóveis, sob os quais incide o IPTU, desatualizados.

A seguir um panorama estatístico dos processos informatizados nas Prefeituras brasileiras (IBGE Pesquisa de Informações Básicas Municipais, 2001):

- Folha de pagamento $95 \%$

- Contabilidade $94 \%$

- Cadastro de funcionários $90 \%$

口 Controle da execução orçamentária $89 \%$

- Cadastro ou banco de dados de saúde $77 \%$

口 Cadastro imobiliário (IPTU) 76\%

- Cadastro de ISS $63 \%$

口 Cadastro de alvarás $61 \%$

- Cadastro ou banco de dados de educação $60 \%$

๑ Cadastro ou banco de dados de patrimônio $57 \%$

口 Tem e-mail $24 \%$

๑ Mapeamento digital $10 \%$ 


\section{2- Administração de TI no Governo}

Esta dimensão da revisão bibliográfica tem por objetivo reunir e organizar estudos acadêmicos relevantes para caracterizar a relação existente entre administração pública de TI e viabilidade do "Governo Eletrônico". A conjuntura da administração pública de TI é fundamental para caracterizar o ambiente onde os projetos de "Governo Eletrônico" são desenvolvidos.

Estágios da utilização da TI na administração pública

Holden (1999) apud Cunha (2000) mostra a evolução da administração de TI na área pública. Desenvolve um modelo de maturidade da administração de TI para a área pública em 3 estágios: Administração de Sistemas de Informação, Administração dos Recursos de Informação e Administração da TI na Era da Informação.

01-Administração de Sistemas de Informação: o objetivo estratégico primário era, neste estágio, aumentar a eficiência das atividades operacionais. Os profissionais de informática focavam o desenvolvimento de aplicações e sistemas. Raramente as funções de linha das organizações controlavam os seus recursos de computação, havia centralização em Centros de Processamento de Dados e a tecnologia era a de "mainframe". As tentativas de melhor atender às expectativas e frustração do corpo gerencial das organizações fixaram-se na tecnologia e no ciclo de vida, e os sistemas de informação de que as organizações públicas necessitavam continuaram não sendo construídos, apesar dos esforços desenvolvidos.

02- Administração dos Recursos de Informação: com a descentralização do poder de computação provocada pela microinformática, as estratégias de gestão dos recursos de informática tiveram que incorporar as organizações usuárias de TI. Neste estágio, apesar de haver tentativas de alinhar a função de TI à organização e aos seus objetivos estratégicos, a ênfase continuou sendo largamente a mesma - eficiência. Houve avanço - da eficiência do "back-office" para a eficiência do governo na prestação de serviços ao público, mas o objetivo continuou sendo a obtenção de custos menores.

03- Administração da TI na Era da Informação: o terceiro estágio, vislumbra a utilização da TI de uma maneira mais orientada aos serviços. A automação, além de fazer as operações internas do governo mais eficientes, deve prover para o público serviços com maior qualidade e no prazo mais adequado. Neste estágio, aparece o gerenciamento dos recursos de informação alinhados à missão organizacional - um item da administração estratégica. É necessária uma maior compreensão da importância da infra-estrutura tecnológica, e a sua gestão, de um ponto de vista organizacional e estratégico. 
Para mostrar o movimento em relação a uma nova visão de administração estratégica dos recursos de informação, Holden (1999) cita as práticas sugeridas para as organizações federais americanas:

- controlar, dirigir as mudanças na Administração dos Recursos de Informação;

- integrar o processo de tomada de decisão da Administração dos Recursos de Informação no processo de administração estratégica;

- alinhar metas estratégicas da organização e resultados da Administração dos Recursos de Informação pelo gerenciamento de resultados;

- conduzir a estratégia de projeto da Administração dos Recursos de Informação e acompanhála utilizando uma filosofia de investimento;

• usar inovação no processo de negócio para impulsionar as estratégias de Administração dos Recursos de Informação; e

๑ construir parceria entre a linha funcional e a Administração dos Recursos de Informação pela liderança e habilidades técnicas.

Estas práticas estão ligadas à prática de planejamento estratégico, performance de missão e medidas de efetividade. Implicam em uma abordagem do gerenciamento do ciclo de vida da TI que una planos, investimentos e resultados de TI.

A tese de Cunha (2000) apresenta três estudos para entendimento dos estágios de utilização da TI na administração pública brasileira: pelos modelos de Nolan, Kraemer e Venkatraman (Reinhard, 1993), pela motivação da informatização (Reinhard, 1999) e pela interação do governo com a sociedade (Cruz, 1999).

Reinhard (1993) descreve a pesquisa realizada no início dos anos 90 sobre a informatização do Governo Federal. Conduzida pela FIA - Fundação Instituto da Administração foi feita por demanda do Instituto de Planejamento Econômico e Social. A pesquisa foi conduzida sob três perspectivas - os estágios de informatização de Nolan (1979), o modelo político proposto por Kraemer (1987) e o impacto dos sistemas de informação proposto por Venkatraman (1991).

Estas classificações pretendem organizar a história da utilização e do gerenciamento de computadores e de TI (TI). Nolan, em 1979, desenvolveu um modelo que se transformou numa referência para a administração dos recursos de informática, mesmo após criticado, alterado e/ou expandido por outros autores. Propôs que o uso e a gestão da informática em uma organização são caracterizados por seis estágios: 1) iniciação; 2) disseminação (ou contágio); 3) controle; 4) integração; 5) administração de dados e 6) maturidade. Cada estágio é definido pelo tipo de aplicações encontradas, pela organização da informática, pela forma de planejamento e controle da informática e pela tecnologia empregada. É 
no estágio de maturidade que a organização está apta para o uso pleno da informação como um recurso.

Kraemer (1987) propôs estágios de administração da computação por uma perspectiva política da administração de informática: 1) competência (grupos técnicos de informática que buscam atualização tecnológica e uso eficiente dos recursos); 2) serviço (usuários em busca de eficácia dos serviços a longo prazo) e; 3) controle (administração superior que precisa harmonizar as demandas por recursos e assegurar o desempenho do órgão no contexto organizacional e político).

Venkatraman (1991) enfatiza o impacto dos sistemas sobre a configuração das organizações: 1) exploração localizada em uma mesma função ou atividade; 2) integração das atividades dentro de uma mesma organização ou processo; 3) redesenho do processo em função dos recursos de informática; 4) redesenho da rede de comunicação externa da organização; 5) redefinição dos objetivos da organização em função das novas possibilidades tecnológicas.

Organizações do mesmo ramo de negócio e do mesmo porte podem estar em estágios de maturidade diferente no uso e gestão dos recursos de TI. Dentro de uma organização e, especialmente nas de grande porte e/ou complexas, como é o caso de muitas das organizações governamentais, os setores ou departamentos podem também estar em estágios de maturidade diferentes. Conforme Reinhard (1993), naquela época, segundo a ótica da primeira perspectiva - os estágios de Nolan - nenhuma organização do governo federal havia atingido o estágio de integração (o quarto, entre seis), e poucas haviam avançado em sua direção para sair do estágio de controle (o terceiro).

Segundo a abordagem do modelo político de Kraemer (1987), a evolução do uso e da gestão da informática havia sido semelhante - a expansão das funções de governo nas décadas de 60 e 70 , favorecendo o grupo competência, escassez dos recursos para informática nos anos 80, favorecendo o grupo controle e tendências de descentralização e cobrança de serviços pela sociedade, favorecendo o grupo serviços.

Usando o modelo de Venkatraman (1991), que enfatiza o impacto dos sistemas sobre a configuração da organização, chegaram a poucas aplicações que não do estágio de exploração localizada, por serem estas de fácil implantação, escopo restrito e terem poucas interfaces organizacionais. Algumas aplicações de integração interna, e raras no redesenho de processo e redesenho de rede.

Ainda que o diagnóstico de informatização não tenha sido repetido nem na esfera federal, nem na estadual ou municipal, Cunha, Morgado e Reinhard (1996) mostraram que as preocupações estratégicas dos executivos de informática da administração pública estadual em 1996 já eram 
dirigidas mais à aplicação da TI ao negócio do governo e menos às questões técnicas ou de controle. Nesta pesquisa, mostrou-se que os Estados tinham agendas de preocupações heterogêneas na aplicação de informática, decorrentes de estágios (estados?) de informatização também diferentes. Se algumas organizações de informática pública ainda estavam tentando demonstrar a importância da TI para a gestão pública, outras já tinham como principal preocupação o alinhamento das ações da área com a concretização dos planos de governo.

Esta pesquisa tipificou 04 grupos: Posicionando a informática, Uso estratégico de informática, Um novo papel para a informática pública e Ênfase na gestão interna. O grupo Uso estratégico de informática descrevia executivos que focalizavam suas ações na concretização de projetos do governo. Estavam empenhados no uso estratégico da informática pelo poder político, no emprego da tecnologia no negócio da administração pública, atrelado aos planos e projetos de governo. Para os executivos do grupo Um novo papel para a informática pública, a importância da TI para a administração pública já estava estabelecida nos Estados que representavam. Não existia discordância a respeito do valor e da importância da Informática e dos Sistemas de Informação.

Estes executivos já estavam em 1996 com sua agenda de preocupações estratégicas voltada ao negócio da administração pública. Entre as questões-chave tabeladas estavam Implementar comunicação eletrônica com todos os segmentos da sociedade e conseguir usar SI para concretização dos projetos do governo.

Reinhard (1999), propõe uma descrição da história da utilização de computadores pela administração pública brasileira, com ênfase na aplicação (motivação) que se deu à Tecnologia (ver Quadro 01). Na era do "Processamento de Dados "o objetivo foi automatizar processos, tanto no setor público como nas organizações privadas. $\mathrm{O}$ desafio que os profissionais de informática do setor público enfrentaram foi entender e automatizar as atividades isoladas. Por vezes, conseguiu-se automatizar processos inteiros e por vezes, menos, houve oportunidade para mudar processos, redesenhá-los como um todo com o uso da TI.

$\mathrm{Na}$ era da "Informação", a ênfase da aplicação da tecnologia nas organizações é focar no indivíduo, no cliente. O paralelo para a área pública é o atendimento ao cidadão, facilitar a vida do usuário de serviços públicos e melhorar a comunicação dele com o Estado. Este usuário pode ser ou um cidadão ou uma organização, privada ou do terceiro setor, ou mesmo pública.

Na era do processamento de dados, quando se iniciou a "Administração dos Recursos de Informação" (o estágio 3), os problemas de integração foram a barreira a ultrapassar. O fracasso de sistemas davase por problemas de integração organizacional. A gestão dos sistemas de informação tinha que se 
focar nos problemas das organizações para garantir que se alcançassem os benefícios desejados.

O estágio 04 foi, para a área pública federal, a época de instalação dos grandes "Sistemas estruturadores de processos interorganizacionais". Sistemas que davam suporte a atividades comuns a várias organizações, estruturadores da função pública. O SIAFI (Sistema Integrado de Administração Financeira do Governo Federal) por exemplo, para que fosse implantado, dependia de condições favoráveis muito fortes, de vontade política (Reinhard, 1995). Foi um sucesso pela articulação bem feita dos vários parceiros e atores do processo. A motivação, nesse estágio, foi viabilizar o todo da administração pública, mas freqüentemente os benefícios a atingir não eram quantificáveis. Na administração estadual e municipal este estágio foi anterior ao da esfera federal, alguns destes sistemas foram desenvolvidos no início do processo de informatização (como os sistemas de folha de pagamento e de controle orçamentário e financeiro).

Para caracterizar o estágio 05 "Desintermediação da comunicação com o público", a palavra-chave foi desintermediação, ou seja, a simplificação de processos. No estágio anterior, descentralização havia sido a preocupação. Agora, houve uma recentralização dos sistemas, com capilarização dos pontos de atendimento que no limite chegou a um ponto de atendimento para cada indivíduo. A inteligência do sistema foi centralizada, a ponta tem pouca inteligência, um "browser" comum a outras aplicações é suficiente.

No estágio 06, acontece a criação de "Centros de atendimento integrados ao público", sejam eles num local físico como as Ruas da Cidadania (PR), os SACs (BA) ou os Poupa-Tempo (SP), ou através de um Portal na Internet. Os objetivos são atingidos se o cidadão consegue através de um ponto único resolver todas as suas demandas com o governo, o que requer integração de processos de negócio numa forma única. Enfrentam-se empecilhos de natureza cultural, processual e até de natureza jurídica. $\mathrm{Na}$ área municipal o desafio é maior pela diversidade de processos, pela natureza das demandas e pelas múltiplas formas de atendimento ao cidadão.

A construção desta etapa, prestação de serviços integrados, ainda está distante da prática atual na maioria dos Estados e Municípios brasileiros. Ela acontecerá, já que há demanda do cidadão que já tem na iniciativa privada a oferta de serviços eletrônicos, há tecnologia disponível e existe a possibilidade de ganhos significativos na qualidade e velocidade do processo de atendimento ao cidadão e empresas. Os serviços baseados em TI oferecidos pela iniciativa privada servem de referência à sociedade, podem criar no cidadão um novo paradigma de qualidade na prestação de serviços públicos. Uma atitude ativa dos governos nesta direção alavancará as ações que hoje são tomadas pelas organizações governamentais de maneira isolada. Passa pela simplificação de processos, pela construção de sistemas amigáveis, seguros e confiáveis, pela democratização do 
acesso que envolve a disponibilização de recursos de informática e comunicação a todos os cidadãos e pela construção de serviços que integrem processos e organizações públicas, privadas e nãogovernamentais (Reinhard, 1999).

\begin{tabular}{|c|c|c|c|}
\hline Era & Estágio & Descrição & Ênfase \\
\hline \multirow[t]{4}{*}{$\begin{array}{l}\text { Processamento } \\
\text { de Dados }\end{array}$} & 1 & $\begin{array}{l}\text { Controle físico de documentos, } \\
\text { antecede a automação }\end{array}$ & Execução das tarefas \\
\hline & 2 & $\begin{array}{l}\text { Processamento de Dados, } \\
\text { baseados em sistemas isolados } \\
\text { para funções específicas }\end{array}$ & $\begin{array}{l}\text { Eficiência das } \\
\text { atividades, controle } \\
\text { gerencial }\end{array}$ \\
\hline & 3 & $\begin{array}{l}\text { Administração dos recursos da } \\
\text { Informação. Descentralização } \\
\text { parcial dos recursos, integração } \\
\text { de aplicações e } \\
\text { compartilhamento de recursos de } \\
\text { rede }\end{array}$ & $\begin{array}{l}\text { Eficácia dos processos } \\
\text { de gestão da infra- } \\
\text { estrutura }\end{array}$ \\
\hline & 4 & $\begin{array}{l}\text { Sistemas estruturadores de } \\
\text { processos interorganizacionais }\end{array}$ & $\begin{array}{l}\text { Desempenho do } \\
\text { negócio }\end{array}$ \\
\hline \multirow[t]{2}{*}{ Informação } & 5 & $\begin{array}{l}\text { Desintermediação da } \\
\text { comunicação com o público }\end{array}$ & Competitividade \\
\hline & 6 & $\begin{array}{l}\text { Centros de atendimento } \\
\text { integrado ao público, num local } \\
\text { físico ou através de um portal na } \\
\text { Internet }\end{array}$ & $\begin{array}{l}\text { Atendimento integrado } \\
\text { à pessoa }\end{array}$ \\
\hline
\end{tabular}

QUADRO 01 - Do cartão perfurado à Internet (Reinhard, 1999)

Conforme Reinhard (1993), a informática publica está em transição motivada por mudanças tecnológicas (comunicação de dados, "downsizing", interfaces para comunicação homem-máquina etc.), revisão do papel e da estrutura do governo (redistribuição das funções entre os níveis federal, estadual e municipal, privatização etc.) e imagem nem sempre favorável dos serviços atuais de informática perante os usuários. Existe mudança de ênfase nas novas aplicações: de instrumento de controle operacional, a informática passa a integrar e, por vezes, ser o elemento essencial do próprio serviço prestado pelo governo. Por outro lado, há iniciativas importantes de sistemas interorganizacionais e proliferação de aplicações de produtividade pessoal locais feitas pelos próprios usuários.

A evolução da função informática pode ser vista a partir de três perspectivas; através de estágios de desenvolvimento, resultado de processo de aprendizagem; como estados que resultam do equilíbrio (temporário) de forças na empresa; pode-se ainda classificar as aplicações de acordo com o nível de integração dos agentes internos e externos. Estas perspectivas, além de seu valor descritivo, permitem fazer inferências sobre a eficácia da função informática e as estratégias gerenciais apropriadas para cada caso. A escassez de recursos do governo também dificulta aos órgãos iniciarem projetos típicos do estágio de integração, os quais requerem investimentos pesados em infra-estrutura e software. 
A prestação de serviços públicos e de informação ao cidadão suportada pela TI

Uma das abordagens possíveis para o estudo da prestação de serviços e da comunicação com o cidadão pela Internet é a teoria de "Comércio Eletrônico". No Brasil, já são efetuadas transações eletrônicas entre governo e cidadão nas esferas dos governos federal, estadual e municipal. Começam mesmo a surgir demandas de regulamentação tais como as de pagamento eletrônico e assinatura eletrônica, embora a prática atual tanto de pagamento eletrônico de serviços públicos como a existência de documentos assinados eletronicamente ainda seja incipiente.

Por estas diferentes perspectivas, a prestação de serviços eletrônicos ao cidadão e a disponibilização de informações pode, em muitos casos, ser considerada como aplicação de "Comércio Eletrônico". Albertin (1997) propõe um Modelo Integrado de Comércio Eletrônico, que contempla as várias modalidades que compõem o CE na sua integração com o ambiente. Este modelo utiliza o conceito de camadas, cada componente afeta os outros e é por eles afetado. O modelo é composto de cinco camadas (ver Figura 04).

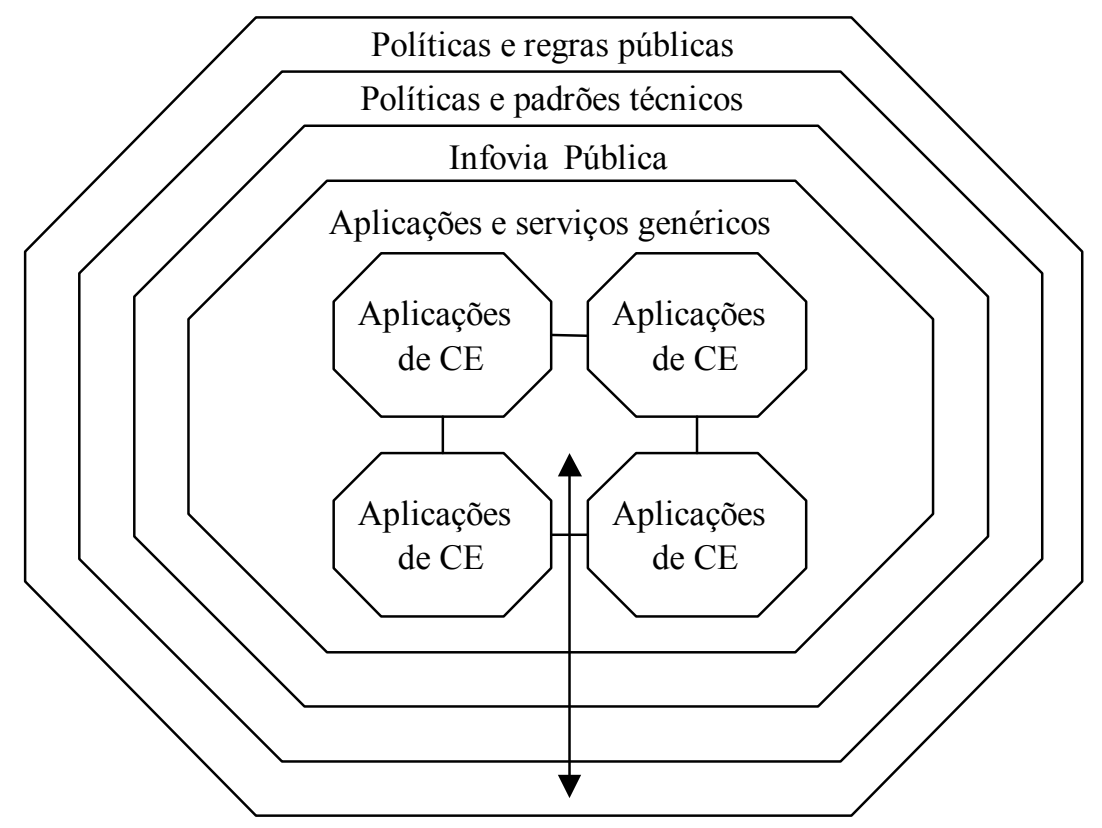

FIGURA 04 - Modelo Integrado de "Comércio Eletrônico" (Albertin, 2000)

A-Políticas e regras públicas: relacionadas aos aspectos legais, regulamentação dos setores e mercados, normas oficiais, etc.

B-Políticas e padrões técnicos: relacionados aos aspectos de padronização para a compatibilização do ambiente técnico, políticas de tratamento e comunicação de informações, interfaces, etc.

C-Infovia pública: a rede formada tanto pela Internet como pelos serviços "on-line" que tenham ligações com ela, sendo que a ênfase é no acesso livre e de baixo custo e na integração entre os ambientes sem nenhuma restrição, incluindo desde os terminais mais simples de acesso até meios de comunicação mais sofisticados para grandes volumes de informação. 
D-Aplicações e serviços genéricos: aqueles oferecidos pelo ambiente através de seus provedores, serviços "on-line" e fornecedores disponíveis a todos, tais como correio eletrônico, transferência de arquivos, salas virtuais, algoritmos e software de criptografia, etc.

E-Aplicações de Comércio Eletrônico: aquelas desenvolvidas com base nas camadas anteriores e que atendam às necessidades de uma organização ou grupo delas, tais como "home banking", vídeo sob demanda, "shopping centers" virtuais, etc.

A seta que une as camadas entre si, determina a influência que cada uma exerce sobre as demais e a influência recebida. A influência de uma camada está limitada pelas restrições impostas pelas demais, assim como ela limita as demais. Por outro lado, cada uma viabiliza a existência das outras e fornece a base e os recursos para que possam se desenvolver. Cada camada tende a exigir a adequação e a evolução das demais, de acordo com a sua própria evolução, necessidades e oportunidades que oferece ao ambiente externo. Albertin (2000) sugere uma estrutura para análise de Comércio Eletrônico, um conjunto de aspectos e benefícios a serem considerados nos seus estudos e aplicações (ver Quadro 02).

\begin{tabular}{|c|c|c|}
\hline Categorias & Aspectos & Contribuições \\
\hline $\begin{array}{l}\text { Clientes e } \\
\text { Fornecedores }\end{array}$ & $\begin{array}{ll}\text { - } & \text { Adoção } \\
\text { - } & \text { Relacionamento }\end{array}$ & - Relacionamento \\
\hline Produtos e Serviços & - $\quad$ Adequação & $\begin{array}{l}\text { - } \quad \text { Customização em massa } \\
\text { - } \quad \text { Inovação de produtos } \\
\text { - Novos canais de } \\
\text { venda/distribuição } \\
\text { - } \quad \text { Promoção de produtos }\end{array}$ \\
\hline Organização & $\begin{array}{l}\text { - Estratégia } \\
\text { - Comprometimento } \\
\text { organizacional }\end{array}$ & $\begin{array}{l}\text { - } \quad \text { Novas oportunidades de } \\
\text { negócio } \\
\text { - } \quad \text { Estratégia competitiva }\end{array}$ \\
\hline Tecnologia & $\begin{array}{l}\text { - } \quad \text { Privacidade e Segurança } \\
\text { - Sistemas eletrônicos de } \\
\text { pagamento } \\
\text { - Aspectos legais } \\
\text { - } \quad \text { Aspectos de implementação }\end{array}$ & $\begin{array}{ll}\text { - } & \text { Economia direta } \\
\text { - } & \text { Infra-estrutura pública }\end{array}$ \\
\hline
\end{tabular}

QUADRO 02 - Estrutura da análise de "Comércio Eletrônico" (Albertin, 2000)

Cunha (2000) explica os aspectos do "Comércio Eletrônico" de Albertin (2000): a chave para o sucesso do sistema de "Comércio Eletrônico" é sua adoção por grande parte dos clientes; o relacionamento com eles tende a ser significativamente alterado com a adoção intensa destas tecnologias; o "Comércio Eletrônico" oferece novas e revolucionárias maneiras de reformatar os processos de negócio, já que os produtos e serviços atuais nem sempre se adequam às novas formas de divulgação, venda, e distribuição agora possíveis; exigência por alteração de estratégias, face à grande quantidade de novas oportunidades; comprometimento organizacional traduzido em investimentos organizacionais - criação e manutenção de sistemas, administração de mudanças, 
gerenciamento de riscos, por exemplo; a fonte potencial de problemas que é privacidade e segurança; um ambiente simples, universalmente aceito, seguro e barato em que as trocas financeiras ocorram, com os sistemas de pagamento eletrônico; os aspectos legais, por exemplo a regulamentação de um setor, podem representar empecilhos à implantação e uso das tecnologias e, ainda, os aspectos de implementação, já citados.

As contribuições são as seguintes: relacionamento (já que os ambientes intermediados por computadores permitem novas maneiras de alcançar consumidores); inovação e customização de produtos (a tecnologia possibilita novos produtos, e os já existentes, podem ser customizados de maneira inovadora e em massa); novos canais de venda e distribuição (devido ao alcance direto e bidirecional da tecnologia); promoção de produtos por meio de contato interativo com os clientes e rico em informações; novas oportunidades de negócio pela oportunidade de construção de novos modelos de negócios baseados na ampla disponibilidade de informações e sua distribuição direta a clientes e fornecedores; estratégia competitiva (na aplicação da tecnologia nas forças competitivas do modelo Porter (1991), reforçando-as quando a favor, ou diminuindo-as quando contra); economia direta porque a utilização de infra-estrutura pública compartilhada, como a Internet, reduz custos de comercialização, distribuição e serviços a clientes e; infra-estrutura pública (cuja criação e utilização é a forma de garantir o acesso fácil e livre a um custo não-proibitivo ao ambiente digital).

Ainda para Albertin (2000) as contribuições das tecnologias de "Comércio Eletrônico" para o setor público são a divulgação de informações, a redução de custos operacionais e a criação de plataforma pública.

- A divulgação de informações de censo coletadas e estruturadas, na dimensão do governo auxiliar seus negócios locais a alcançar mercados estrangeiros. Mas esse conceito pode ser ampliado - divulgação de informações de políticas públicas (incentivos às empresas, por exemplo), de práticas de governo, de prestação de contas à sociedade.

- Redução de custos operacionais para o governo na utilização de comunicação eletrônica entre administrações e companhias privadas, além de estimular a atividade do setor privado. Podese ampliar este conceito para a redução de custos operacionais também dentro das companhias privadas, na medida que se seu relacionamento com o governo é mais simples, e eletrônico, exige, por exemplo, menor consumo de recursos humanos, diminui os custos das empresas.

- Criação de plataforma pública, governos tomam esta iniciativa quando a postura competitiva de uma região ou nação está ameaçada, quando os elementos chave de uma plataforma eletrônica exigem grandes ações de uma administração de governo ou quando a padronização tem que ser forçada. 
A definição do modelo de Albertin para "Comércio Eletrônico" é particularmente centrada em alavancagem econômica. A atuação do governo por vezes tem esta dimensão, a de troca comercial, na prestação de inúmeros serviços públicos e de informação. Em grande parte deles, há exigência por pagamento. Mas o modelo de análise neste trabalho deve extrapolar a troca comercial para representar aspectos importantes à atuação do governo, mesmo considerando que a construção de um modelo é sempre uma simplificação da realidade e portanto não a representará completamente.

Conforme Fernandes (2000), o desenvolvimento do governo digital passa, geralmente, por quatro estágios. O primeiro consiste na criação de "sites" para a difusão de informações sobre os mais diversos órgãos e departamentos dos diversos níveis de governo. Eventualmente, esses "sites" são reunidos em um portal que, neste estágio, consiste apenas em uma espécie de catálogo de endereços dos vários órgãos do governo.

No segundo estágio, estes "sites" passam também a receber informações e dados por parte dos cidadãos, empresas ou outros órgãos. A comunicação neste caso torna-se uma via de mão dupla. $\mathrm{O}$ contribuinte pode enviar sua declaração de imposto de renda ou informar uma mudança de endereço; são criados endereços eletrônicos para receber reclamações ou sugestões nas diversas repartições; firmas se cadastram eletronicamente para o fornecimento de certos serviços; dados são transferidos, usando a Internet, de um departamento ou de uma prefeitura ou de uma unidade hospitalar, por exemplo, para um órgão central, e assim por diante.

$\mathrm{Na}$ terceira etapa de implantação, as transações se tornam ainda mais complexas. Neste estágio, são possíveis trocas de valores que podem ser quantificáveis. São realizadas operações como pagamentos de contas e impostos, educação à distância, matrículas na rede pública, marcação de consultas médicas, compras de materiais, etc. Em outras palavras, além de informações, valores são trocados e serviços anteriormente prestados por um conjunto de funcionários atrás do balcão são agora realizados usando uma plataforma de rede e uma interface direta e imediata com o cidadão ou empresa. Isto implica adaptações nos processos de trabalho.

Estas modificações tornam-se ainda mais complexas e radicais no quarto estágio de implantação. Nele, é desenvolvido um tipo de portal que não é mais um simples índice de "sites" do governo com centenas de endereços, mas um lugar de convergência de todos os serviços prestados pelo governo. Neste estágio, o serviço é disponibilizado por funções ou temas, e não segundo a divisão real do governo em ministérios, departamentos, etc.

Assim, ao lidar com o governo, cidadãos ou empresas não precisam mais dirigir-se a inúmeros órgãos diferentes para procedimentos como mudar de estado civil, requerer seguro-desemprego, abrir uma 
firma ou obter uma determinada licença. É possível resolver tudo em um único lugar, com uma única senha. O usuário não tem de saber quais órgãos ou departamentos, de quais níveis de governo e em que seqüência são mobilizados para a realização de um determinado serviço ou a prestação de uma informação. O que acontece por detrás da interface eletrônica (off-line) não interessa a ele.

Segundo Fernandes (2000), para que isso seja possível, contudo, é necessária uma mudança radical nos bastidores, pois muitos dos serviços a serem realizados exigirão uma intensa colaboração entre os diversos órgãos e -repartições, por meio de uma Intranet governamental segura, que integre todos eles. Em outras palavras, num estágio avançado do governo digital, automação de atividades e racionalização dos procedimentos implicam transformações radicais dos processos de trabalho, e não apenas agilização destes processos. O desenvolvimento da interoperabilidade entre os vários órgãos da administração pública, enfim, torna premente uma verdadeira reforma administrativa do Estado. E não é possível levar esta tarefa a cabo sem um intenso programa de treinamento e reciclagem de todos os funcionários públicos.

E mais, de forma geral, pode-se dizer que, na maioria dos países, os princípios gerais que orientam a presença do governo na Internet, qualquer que seja o seu estágio, são a democratização do acesso à informação, a universalização na prestação dos serviços públicos, a proteção da privacidade individual e a redução das desigualdades sociais e regionais. Para isso, são pré-requisitos básicos do desenvolvimento do governo digital uma avançada infra-estrutura de redes e de computação e um quadro jurídico-institucional adequado. Vale lembrar que o desenvolvimento do "Governo Eletrônico" deve acompanhar as transformações da sociedade. Por um lado, o governo tem de estar apto para seguir o ritmo das mudanças tecnológicas que estão ocorrendo na economia interna e de outros países, dando respostas rápidas e adequadas às demandas daí decorrentes, por parte tanto dos cidadãos quanto das empresas. Por outro lado, ele deve garantir que todos possam ser capazes de interagir com ele por meio destas tecnologias. Em outros termos, o governo deve assegurar a educação digital de toda a população, preservando o exercício pleno da cidadania.

Estágios da utilização da Internet no governo, segundo "site" do governo federal:

- Emergente: uma presença oficial do Governo na Internet é estabelecida.

- Aprimorado: os "sites" do Governo aumentam; informação se torna mais dinâmica.

- Interativo: usuários podem baixar formulários, enviar e-mail a representantes e interagir pela Internet.

- Transacional: usuários podem pagar por serviços e outras transações on-line.

- Integrado: integração completa dos serviços eletrônicos, eliminando limites da estrutura administrativa. 
Já no entender de Seybold (2000), as organizações normalmente passam por cinco estágios distintos em suas iniciativas de negócios suportados pela Internet: 1- Fornecer informações sobre a organização e os produtos; 2- Fornecer suporte ao cliente e possibilitar interações; 3- Dar suporte às transações eletrônicas; 4- Personalizar as interações com os clientes e; 5- Fomentar a comunidade.

A autora apresenta ainda uma estratégia de implementação para "Comércio Eletrônico" em cinco etapas, após estudar mais de 40 empresas que já o implementaram com sucesso:1- Definir a estratégia: facilitar os negócios do cliente com sua organização; 2- Enfocar o cliente final de seus produtos e serviços; 3- Redesenhar os processos de negócio sob a ótica do cliente, do ponto de vista do cliente; 4- Conectar sua empresa para obter resultado: conceber uma arquitetura de negócios eletrônicos abrangente e progressiva e ; 5- Fomentar a lealdade do cliente, a chave do sucesso e rentabilidade no "Comércio Eletrônico".

\section{Um Modelo para Utilização da Tecnologia Internet pelo Governo}

O trabalho de Backus (2001) explica o significado do termo "Governo Eletrônico" e apresenta um modelo geral para utilização e implementação da tecnologia Internet pelo Governo (ver Figuras 05 e 06). São discutidos aspectos tecnológicos e apresentada uma análise SWOT para países em desenvolvimento. Finalmente, tem-se uma descrição das etapas de ajustes políticos-estratégicos e como implementar projetos utilizando tecnologia Internet no governo.

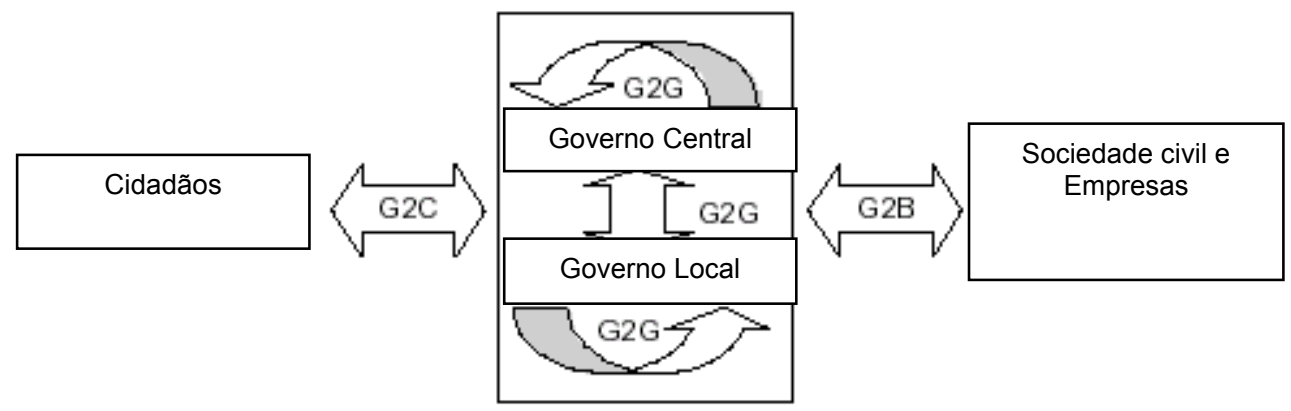

FIGURA 05 - Interação entre os grupos envolvidos na Utilização da Tecnologia Internet pelo Governo (Gartner Group, 2000)

O Gartner Group, uma reconhecida empresa internacional de consultoria e pesquisa, tem apresentado um Modelo para Utilização da Tecnologia Internet pelo Governo em quatro fases. Este modelo serve como referência para posicionar onde um Projeto se enquadra na evolução geral da Utilização da Tecnologia Internet pelo Governo. Estas fases foram definidas com base em experiências dos governos europeus e países ocidentais.

Geralmente, os governos iniciam o utilização da Tecnologia Internet disponibilizando informações 
on-line, mas a demanda pública e a eficiência interna pedem serviços mais complexos

$\begin{array}{lllll}\text { Início dos anos } 90 & = & \text { Informação } & \Rightarrow & \text { Presença } \\ \text { Meio dos anos } 90 & = & \text { Interação } & \Rightarrow & \text { Incremento do processo } \\ \text { Presente } & = & \text { Transação } & \Rightarrow & \text { Transação completa } \\ \text { Futuro } & = & \text { Transformação } & \Rightarrow & \text { Integração e mudanças }\end{array}$
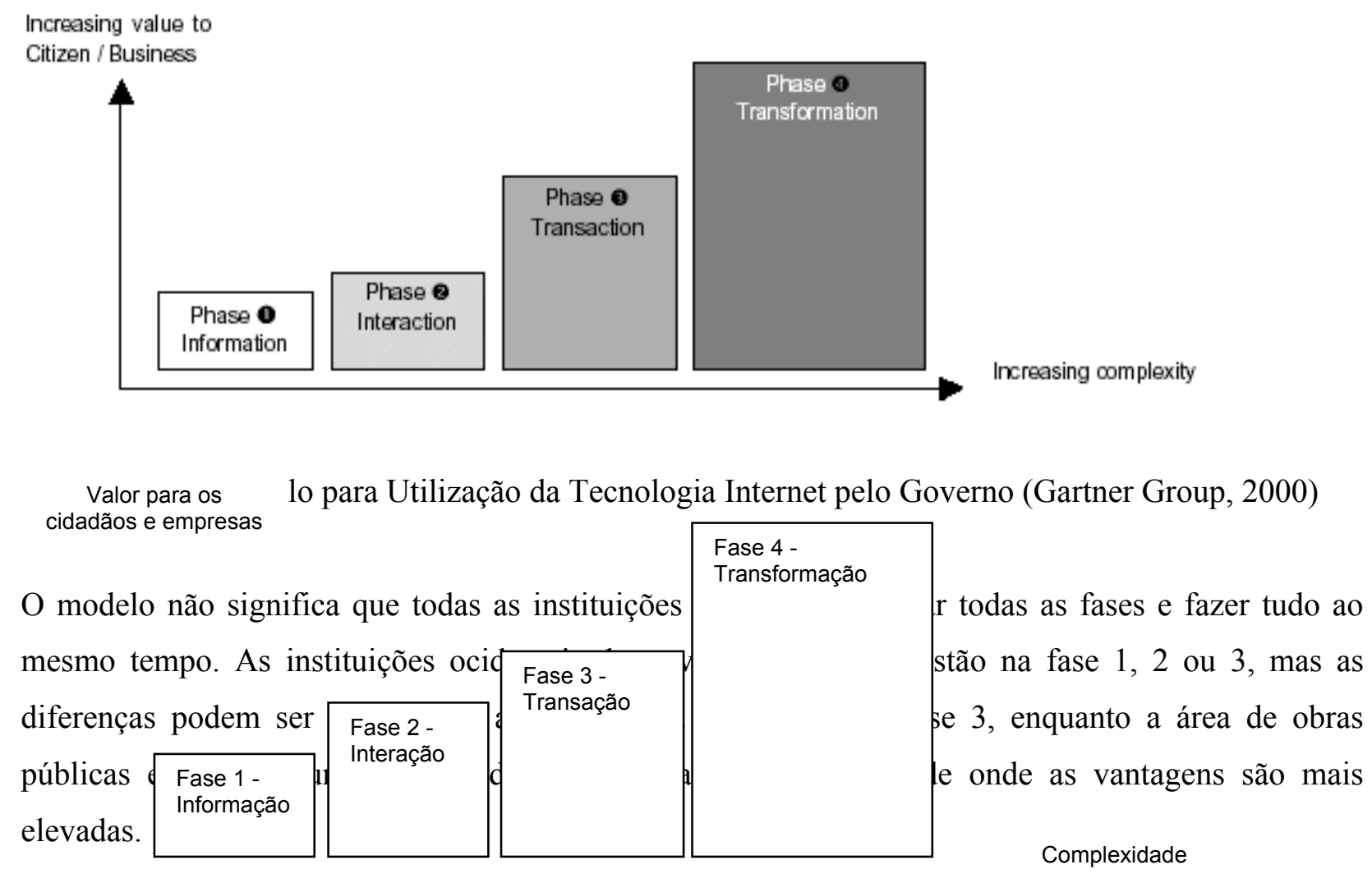

Fase 1 - Informação: Fornece-se ao público externo (G2C e G2b) intormaçoes reıevante. O formato dos primeiros "sites" do governo é similar a brochuras e folhetos. O valor maior é que a informação do governo se torna publicamente acessível; os processos são descritos e tornam-se assim mais transparentes, melhorando a democracia e o serviço. Internamente (G2G) o governo pode também disseminar a informação com meios eletrônicos, tais como o Internet. Esta fase é toda suportada pela informação.

Fase 2 - Interação: Na segunda fase, a interação entre o governo e o público (G2C e G2B) é estimulada com várias aplicações. O público pode fazer perguntas através do e-mail, usar ferramentas de busca para a informação e podem fazer "download" de toda a sorte de formulários e documentos. Estas funcionalidades economizam tempo. A entrada completa de aplicações (simples) pode ser feita em linha 24/7. Internamente as organizações do governo (G2G) usam as redes de área local, as "Intranets" e o e-mail para se comunicar e trocar dados. Mais eficiência e eficácia são conseguidas porque uma parte grande do processo de entrada é 
feita "on-line”. Entretanto, é ainda imprescindível se dirigir ao escritório físico para finalizar a transação, pagar uma taxa, entregar alguma evidência adicional ou assinar papéis. O uso de ferramentas de comunicação eletrônica incrementa a velocidade dos processos internos do governo.

Fase 3 - Transação: Na fase três a complexidade da tecnologia e o valor para o cliente (G2C e G2B) são mais elevados. Podem ser feitas transações completas sem ir a repartição pública. Exemplos de serviços "on-line" são a declaração do imposto de renda e do imposto de propriedade, renovação de licenças, visto e passaportes, etc. A fase três é complexa principalmente por causa das questões de segurança e de personalização, por exemplo, as assinaturas (eletrônicas) digitais são necessárias para permitir transferência legal dos serviços. No lado do negócio, o governo está iniciando com aplicações de leilões e licitações eletrônicas. Nesta fase, os processos $(\mathrm{G} 2 \mathrm{G})$ internos têm que ser redesenhados para melhorar o serviço. O governo necessita criar leis e novas legislações que permitirão transações sem papel com certificação legal. Agora o processo completo é "on-line", incluindo pagamentos, assinaturas digitais, etc.. Isto economiza tempo, papel e dinheiro.

Fase 4 - Transformação: A quarta fase é a fase da transformação em que todos os sistemas de informação são integrados e o público pode obter os serviços G2C e G2B em uma repartição pública virtual. Um único ponto de contato para todos os serviços é o objetivo final. O aspecto mais complexo em alcançar este objetivo está principalmente no lado interno, por exemplo a necessidade de mudar drasticamente a cultura, os processos e as responsabilidades dentro das instituições do governo (G2G). Os empregados de governo em departamentos diferentes têm que trabalhar junto em uma maneira simples e contínua. Nesta fase tem-se significativas economias de custo, a eficiência e a satisfação de cliente estão alcançando os níveis mais elevados possíveis.

No trabalho de Backus (2001) são apresentados elementos que traduzem o Impacto da TI no governo:

- Modelo de serviço 24/7 - Os sistemas e os processos têm que ser adaptados a um modelo completamente novo de serviço. Os processos da entrada são feitos com base no autoatendimento e no meio da noite um cidadão pode demandar uma resposta (automatizada) imediata sobre o status da aplicação. As expectativas dos cidadãos para o tempo de resposta dos governos mudarão por causa dos novos meio de comunicação. O e-mail deve ser visto um novo e crítico canal de comunicação além dos tradicionais tais como o telefone, a repartição física, o correio e o fax.

- Necessidade de Conteúdo - "sites" são compostos por informação. Os governos terão que 
disponibilizar e atualizar o conteúdo diariamente. Na fase 1 o conteúdo será estático, mas na fase 2 o conteúdo estará mudando a cada dia. Os gerentes de conteúdo em cada departamento (grande) são responsáveis pela sua informação no site.

- Recursos Humanos - O efetivo uso da TI em uma organização exige treinamento dos funcionários. O pessoal deve estar confortável com as novas ferramentas, caso contrário podem retornar aos velhos hábitos e padrões de trabalho. Para manter uma infra-estrutura de tecnologia é imprescindível recursos especializados em TI, o governo normalmente terá de recrutá-los da iniciativa privada.

- Segurança - Todo sistema computatorizado é vulnerável a ataques externos. Quando o governo move seus processos principais (informação, comunicação e transações) para o Internet está se tornando mais vulnerável. O Internet aumenta o número de pontos de entrada de maneira exponencial. A proteção é possível com software de anti-vírus, soluções de "firewall", tecnologia de criptografia e ferramentas de autenticação da identificação.

- Privacidade - Nas fases 3 e 4 os governos possuem informações detalhadas sobre cidadãos e empresas que é trabalhada frequentemente em escritórios múltiplos através de diversos sistemas computatorizados diferentes (ou ainda em arquivos de papel). A integração dos dados pode resultar em situações onde a privacidade dos cidadãos individuais está no perigo. É responsabilidade do governo restringir a utilização da informação confidencial, e assegurar que tal informação será acessada por quem de direito. Devido ao interesse público, a questão da privacidade tem levado diversos países a aprovar leis sobre proteção de dados.

- Departamento de TI - Com a implementação de projetos de governança na Internet, a área de TI está se tornando mais e mais importante nas operações do governo. A necessidade de profissionais de TI será inevitavelmente maior, não somente durante a execução, mas também para a manutenção do "software", do "hardware" e da infra-estrutura.

Para Heeks e Davies (1999), os desafios enfrentados pelo governo em relação a TI dizem respeito a:

- Acesso e suporte - Assegurar que o uso da TI pelo governo não crie classes de pessoas - "os que têm" e "os que não têm" informação. É um desafio assegurar ajuda para os usuários de sistemas e serviços baseados nessas tecnologias.

- Encontrar a informação correta - Assegurar que a informação pode ser facilmente encontrada pelos usuários nos sistemas baseados em TI.

- Arquivo e preservação - Assegurar que a informação não será perdida. Assegurar que poderá ser recuperada no futuro pelas novas tecnologias.

- Segurança e privacidade - Assegurar que informações guardadas nos computadores governamentais estão seguras em relação a acessos e alterações acidentais ou malintencionados. 


\section{3-Gerência de projetos e processo de implementação de projetos de TI}

Este capítulo da revisão bibliográfica tem por objetivo sistematizar e apresentar elementos teóricos que sustentam a moderna gerência de projetos, com especial interesse em no processo de implementação de projetos de sistemas de informação. No universo da moderna administração pública voltada para o contribuinte-cidadão, é fundamental que os gestores públicos do "Governo Eletrônico" possuam a adequada capacitação em gerência de projetos e o completo entendimento do processo implementação de projetos de TI, viabilizando a existência do governo na Internet e operações bem sucedidas sob sua responsabilidade.

\section{Caracterização e gerenciamento de Projetos}

Pressman (2002) identificou quatro elementos que compõem o espectro de gestão de projetos de software e TI: pessoas, produto, processo e projeto. $\mathrm{O}$ gerente que esquece que o trabalho de engenharia de software é um empreendimento intensamente humano nunca vai ter sucesso na gestão de projetos. O gerente que deixa de encorajar uma comunicação ampla com o cliente, desde cedo na evolução de um projeto, se arrisca a construir uma solução elegante para o problema errado. O gerente que presta pouca atenção no processo corre o risco de empregar métodos e ferramentas técnicas competentes num vazio. O gerente que começa sem um plano de projeto sólido compromente o sucesso do produto.

A seguir os quatro elementos do espectro de gestão de projetos proposto por Pressman (2002):

PESSOAL - Deve ser organizado em equipe efetivas e motivadas para fazer trabalho de software de alta qualidade e coordenadas para alcançar comunicação efetiva.O fator pessoal é tão importante que o "Software Engineering Institute" desenvolveu um modelo de maturidade da capacitação da gestão de pessoal ("people management capacibility materity model" - PMCMM). Este modelo define as seguintes áreas de práticas-chave para o pessoal de software: recrutamento, seleção, gestão de desempenho, treinamento, remuneração, desenvolvimento de carreira, organização e projeto do trabalho, e desenvolvimento da equipe/cultura.

PRODUTO - Os requisitos do produto devem ser informados pelo cliente ao desenvolvedor, particionados (decompostos) em suas etapas constituintes e posicionados para serem trabalhados pela equipe de software. Antes que o projeto possa ser planejado, devem ser estabelecidos os objetivos e o escopo do produto, as soluções alternativas devem ser consideradas e as restrições técnicas e gerenciais devem ser identificadas. Sem essas informações é impossível definir estimativas de custo razoáveis (e precisas), avaliações efetivas de risco, relações realísticas de tarefas do projeto ou cronogramas de projeto 
gerenciáveis que proprocionem uma indicação significativa do progresso. $\mathrm{O}$ desenvolvedor de software e o cliente devem se reunir para definir os objetivos e o escopo do produto, que uma vez entendidos podem derivar algumas soluções alternativas. Apesar de poucos detalhes serem discutidos, as alternativas permitem a gerentes e profissionais envolvidos selecionar uma "melhor" abordagem, dadas as restrições impostas pelos prazos de entrega, restrições orçamentárias, disponibilidade de pessoal, interfaces técnicas e muitos outros fatores.

PROCESSO - Deve ser adaptado às pessoas e ao problema. Fornece o arcabouço a partir do qual pode ser estabelecido um plano abrangente para o desenvolvimento de software. Algumas atividades de arcabouço são aplicáveis a todos os projetos de software, independente de seu tamanho ou complexidade. Vários conjuntos diferentes de tarefas - tarefas, eventos importantes, produtos de trabalho e pontos de garantia de qualidade - permitem que as atividades de arcabouço sejam adaptadas às características do projeto de software e às necessidades da equipe de projeto.

PROJETO - Deve ser organizado de modo a levar a equipe de software ao sucesso. Conduzir projetos de software planejados e controlados por uma razão principal, é a única forma conhecidade de gerir a complexidade. A fim de evitar falhas de projeto, o gerente de projeto e sua equipe devem evitar um conjunto de sinais de alerta comuns, entender os fatores condicionantes de sucesso, que levam à boa gestão de projetos, e desenvolver uma abordagem de bom senso para planejar, monitorar e controlar o projeto.

Segundo Maximiniano (1997) apud Pinto (2002) projetos são empreendimentos finitos que têm por objetivos claramente definidos em função de um problema, oportunidade ou interesse de uma pessoa ou organização. O resultado do projeto é o desenvolvimento da solução ou atendimento do interesse, dentro das restrições de tempo e recursos. Para definir o grau de sucesso do resultado do projeto, é preciso verificar se estes critérios foram atendidos.

Conforme PMBOK (2000) as organizações executam trabalho. O trabalho envolve serviços continuados e/ou projetos, embora possa haver superposição entre os dois. Serviços continuados e projetos possuem muitas características comuns; por exemplo, ambos são:

- Executados por pessoas.

- Restringidos por recursos limitados.

- Planejados, executados e controlados.

Serviços continuados e projetos diferem principalmente porque enquanto os primeiros são contínuos e repetitivos, os projetos são temporários e únicos. Assim, um projeto pode ser definido em termos de suas características distintas - um projeto é um empreendimento temporário com o objetivo de criar 
um produto ou serviço único. Temporário significa que cada projeto tem um começo e um fim bem definidos. Único significa que o produto ou serviço produzido é de alguma forma diferente de todos os outros produtos ou serviços semelhantes.

Os projetos são desenvolvidos em todos os níveis da organização. Eles podem envolver uma única pessoa ou milhares delas. Podem requerer menos do que 100 horas de trabalho ou até 10.000 .000 ou mais para se completarem. Os projetos podem envolver uma unidade isolada da organização ou atravessar as fronteiras organizacionais, como ocorre com consórcios e parcerias. Os projetos são freqüentemente componentes críticos da estratégia de negócios da organização.

Pode-se citar como exemplos de projetos: Desenvolver um novo produto ou serviço; Implementar uma mudança organizacional a nível de estrutura, de pessoas ou de estilo gerencial; Planejar um novo veículo de transporte; Desenvolver ou adquirir um sistema de informação novo ou modificado; Construir um prédio ou instalações; Levar a cabo uma campanha política;Implementar um novo processo ou procedimento organizacional.

Segundo Dinsmore (1993) apud Pinto (2002) uma importante forma de visualizar o gerenciamento de projetos é entendê-lo como gerenciamento da mudança. O gerenciamento de operações pode ser caracterizado como a administração da rotina operacional. Os executivos tendem a estar preocupados com a implantação de uma nova operação (projeto) para implementar uma estratégia organizacional. Assim que o projeto é finalizado (transformando-se em operação) a preocupação se desloca para a manutenção da operação em um modo eficiente e contínuo. O gerenciamento técnico, por sua vez, tende a focar a teoria, tecnologia, a prática em determinado campo técnico, fatores de segurança no desenho, procedimentos de verificação e outros aspectos. O gerenciamento de projeto é então, a interface entre o gerenciamento geral, o gerenciamento de operações e o gerenciamento técnico, que integram os aspectos de todos os projetos e leva o projeto a sua realização.

Conforme PMBOK (2000) gerência de projetos é a aplicação de conhecimentos, habilidades, e técnicas para projetar atividades que visem atingir ou exceder as necessidades e expectativas das partes envolvidas, com relação ao projeto. $\mathrm{O}$ ato de atingir ou exceder as necessidades e expectativas das partes envolvidas, invariavelmente envolve o equilíbrio entre demandas concorrentes: Escopo, prazo, custo e qualidade; Diferentes necessidades e expectativas das partes envolvidas e; Necessidades concretas e expectativas.

O termo gerência de projetos é algumas vezes usado para descrever uma abordagem organizacional para gerenciamento dos processos operacionais contínuos. Esta abordagem, mais conhecida como gerência por projetos, trata muitos aspectos dos serviços continuados como projetos, objetivando 
aplicar também a eles, os conceitos de gerência de projetos. Embora seja óbvio que o conhecimento de gerência de projetos é essencial para uma organização que aplica a gerência por projetos, uma discussão detalhada dessa abordagem, está fora do escopo deste documento.

As Áreas de Conhecimento da Gerência de Projetos descrevem os conhecimentos e práticas em gerência de projetos em termos dos processos que as compõem. Estes processos foram organizados em nove áreas de conhecimentos:

- Gerência da Integração do Projeto: descreve os processos necessários para assegurar que os diversos elementos do projeto sejam adequadamente coordenados. Ele é composto pelo desenvolvimento do plano do projeto, execução do plano do projeto e controle geral de mudanças.

- Gerência do Escopo do Projeto: descreve os processos necessários para assegurar que o projeto contemple todo o trabalho requerido, e nada mais que o trabalho requerido, para completar o projeto com sucesso. Ele é composto pela iniciação, planejamento do escopo, detalhamento do escopo, verificação do escopo e controle de mudanças do escopo.

- Gerência do Tempo do Projeto: descreve os processos necessários para assegurar que o projeto termine dentro do prazo previsto. Ele é composto pela definição das atividades, seqüenciamento das atividades, estimativa da duração das atividades, desenvolvimento do cronograma e controle do cronograma.

- Gerência do Custo do Projeto: descreve os processos necessários para assegurar que o projeto seja completado dentro do orçamento previsto. Ele é composto pelo planejamento dos recursos, estimativa dos custos, orçamento dos custos e controle dos custos.

- Gerência da Qualidade do Projeto: descreve os processos necessários para assegurar que as necessidades que originaram o desenvolvimento do projeto serão satisfeitas. Ele é composto pelo planejamento da qualidade, garantia da qualidade e controle da qualidade.

- Gerência dos Recursos Humanos do Projeto: descreve os processos necessários para proporcionar a melhor utilização das pessoas envolvidas no projeto. Ele é composto pelo planejamento organizacional, montagem da equipe e desenvolvimento da equipe.

- Gerência das Comunicações do Projeto: descreve os processos necessários para assegurar que a geração, captura, distribuição, armazenamento e pronta apresentação das informações do projeto sejam feitas de forma adequada e no tempo certo. Ele é composto pelo planejamento das comunicações, distribuição das informações, relato de desempenho e encerramento administrativo.

- Gerência dos Riscos do Projeto: descreve os processos que dizem respeito à identificação, análise e resposta a riscos do projeto. Ele é composto pela identificação dos riscos, quantificação dos riscos, desenvolvimento das respostas aos riscos e controle das respostas 
aos riscos.

- Gerência das Aquisições do Projeto: descreve os processos necessários para a aquisição de mercadorias e serviços fora da organização que desenvolve o projeto. Ele é composto pelo planejamento das aquisições, preparação das aquisições, obtenção de propostas, seleção de fornecedores, administração dos contratos e encerramento do contrato.

\section{O Contexto da gerência de projetos}

Tanto os projetos quanto a gerência de projetos se inserem num ambiente bem mais amplo do que o projeto propriamente dito. A equipe de gerência do projeto deve compreender este contexto mais amplo - a gerência das atividades diárias do projeto é necessária mas não é suficiente para o seu sucesso.

Como os projetos possuem um caráter único, a eles está associado um certo grau de incerteza. As organizações que desenvolvem projetos usualmente dividem-nos em várias fases visando um melhor controle gerencial e uma ligação mais adequada de cada projeto aos seus processos operacionais contínuos. O conjunto das fases de um projeto é conhecido como ciclo de vida do projeto. Os partes envolvidas são indivíduos e organizações diretamente envolvidos no projeto, ou aqueles cujos interesses podem ser afetados, de forma positiva ou negativa, no decorrer do projeto ou mesmo após sua conclusão. A equipe de gerência do projeto deve identificar as partes envolvidas, conhecer suas necessidades e expectativas e, então, gerenciar e influenciar estas expectativas de forma a garantir o sucesso do projeto. Em todo projeto existem alguns partes envolvidas principais:

- Gerente do projeto: indivíduo responsável pela gerência do projeto.

- Cliente: indivíduo ou organização que fará uso do produto do projeto. Podem existir múltiplas camadas de clientes.

- Organização executora: empresa cujos funcionários estão mais diretamente envolvidos na execução do projeto.

- Patrocinador: indivíduo ou grupo, dentro da organização executora, que provê os recursos financeiros, em dinheiro ou espécie, para o projeto.

Existem diferentes nomes e categorias de partes envolvidas do projeto - interno e externo, proprietários e acionistas, fornecedores e empreiteiros, membros da equipe do projeto e seus familiares, agências do governo, agências de publicidade, cidadãos, intermediadores permanentes ou temporários e a sociedade em geral.

Os projetos fazem, tipicamente, parte de uma organização maior - corporações, agências do governo, instituições de saúde, organismos internacionais, associações profissionais e outros. Mesmo que o 
projeto seja a organização (joint ventures, parcerias) o projeto é ainda influenciado pela organização ou organizações que o estabeleceu. Os tópicos a seguir descrevem os principais aspectos destas organizações estruturais maiores que, provavelmente, irão influenciar o projeto:

- Sistemas da Organização: organizações orientadas a projeto são aquelas cujas operações consistem, basicamente, de projetos. Estas organizações tendem a ter sistemas de gerenciamento voltados para a gerência de projetos. Organizações não orientadas a projeto raramente têm sistemas de gerenciamento projetados para suportar as necessidades dos projetos de forma efetiva e eficiente. A ausência de sistemas orientados a projetos normalmente dificulta a tarefa de gerenciamento de cada projeto. Em alguns casos, as organizações não orientadas a projeto têm departamentos, ou outras unidades administrativas, operando por projetos com sistemas de suporte adequados. A equipe de gerência do projeto deve estar bastante consciente da forma como os sistemas da organização afetam o projeto.

- Estilo e Cultura da Organização: a maioria das organizações desenvolveu cultura única e própria. Esta cultura é refletida nos seus valores, normas, crenças e expectativas; nas suas políticas e procedimentos; na sua visão das relações de autoridade; e em diversos outros fatores. A cultura da organização, freqüentemente, tem influência direta no projeto. Por exemplo, uma equipe que propõe uma abordagem não usual ou de alto risco tem mais chance de aprovação numa organização empreendedora ou agressiva. Ou ainda, um gerente de projeto com estilo altamente participativo é capaz de encontrar problemas numa organização hierárquica rígida, enquanto um gerente de projeto com estilo autoritário será igualmente desafiado numa organização participativa.

- Estrutura da Organização: a estrutura da organização executora freqüentemente restringe a disponibilidade ou as condições sob as quais os recursos se tornam disponíveis para o projeto. As estruturas das organizações podem apresentar um amplo espectro de estruturas, da funcional à projetizada, com uma variedade de combinação entre elas.

\section{O processo de implementação da TI}

Laudon e Laudon (2000) descrevem implementação como todas as atividades organizacionais que levam à adoção, gerenciamento e rotinização de uma inovação. Estes autores apresentam um resumo da literatura de inovação.

Uma parte da literatura foca nos atores do processo e funções que desempenham. Acredita-se que as organizações devem selecionar atores com as características apropriadas (status social, educação superior, sofisticação técnica, social e organizacional) e no processo de inovação sistematicamente desenvolver suas funções, como com a criação de produtos especiais. Uma segunda escola de pensamento na literatura de inovação foca-se na estratégia da inovação. Os dois extremos são 
inovação "top-down" e "grassroot". Há organizações onde a falta de um patrocinador condena o projeto desde o seu início. Ao mesmo tempo, sem "raízes fortes", por exemplo a participação do usuário, o projeto também pode falhar.

A terceira abordagem foca-se nos fatores de mudança organizacional decisivos para a rotinização da inovação no longo prazo, e indicadores de sucesso (Yin, 1981, citado em Laudon e Laudon, 2000). Ações para aumentar a aprendizagem organizacional e adquirir novas práticas e conhecimentos também são úteis. A literatura sobre implementação não descreve uma explicação única para sucessos e falhas relatados. Contudo, revelou que podem ser largamente atribuídos aos seguintes fatores (Laudon e Laudon, 2000): a função do usuário no processo de implementação; o grau de suporte e comprometimento gerencial dado ao esforço de implementação; o nível de complexidade e risco do processo de implementação (tamanho do projeto, estrutura do projeto e experiência na tecnologia) e a qualidade do gerenciamento do processo de implementação.

Kwon e Zmud (1987) estudam os trabalhos sobre implementação de sistemas de informação e sobre inovação. A revisão de literatura de sistemas de informação e de inovação nas organizações que fizeram identificou cinco grandes forças, que representam os elementos constituintes do modelo organizacional de Leavitt (1965) e inclui considerações ambientais (ver Figura 07):

1-Fatores Individuais - as variáveis individuais mais freqüentemente encontradas na literatura foram: a experiência no cargo, relacionada normalmente à legitimidade na instituição; o "cosmopolitanismo", associado à receptividade a mudança; bagagem educacional, também associada à receptividade a mudança; e cargos na organização (mais envolvimento nas funções gerenciais foram propostas ou relatadas como positivamente relacionadas à adoção.

2-Fatores Estruturais - a organização possui estruturas formais e informais e ambas influenciam na introdução de inovações tecnológicas. Os efeitos da estrutura formal no processo de introdução de inovações tecnológicas foram: especialização, referindo-se à diversidade de especialistas na organização, onde a racionalidade técnica é usada para explicar os efeitos positivos; centralização, o grau de concentração na atividade de tomada de decisão, normalmente relacionada negativamente à introdução de inovações tecnológicas; formalização, o grau de diferenciação funcional, que se acredita poder desenvolver uma definição clara do trabalho e procedimentos; e a rede informal. Para haver uma adoção de tecnologia com sucesso numa organização, tem que se implementar um sistema que conserve a estrutura de poder existente, ou a perturbe muito levemente. Isto é particularmente importante ao se falar de sistemas que implantem mecanismos de democracia. A teledemocracia é restringida pela estrutura de poder vigente. 
3-Fatores Tecnológicos - os fatores tecnológicos referem-se à influência das características das inovações no processo de inovação: compatibilidade da inovação; vantagem relativa, ou seja o grau como uma inovação é percebida para a obtenção de maiores benefícios organizacionais ou de "status quo" que outras inovações; e complexidade, o grau dos usuários em entender e usar uma inovação.

4-Fatores relacionados a Tarefas - incerteza na tarefa, o grau de rotinização, capacidade de programação e exceção em cumprir as tarefas organizacionais; autonomia, relacionada ao grau com que os indivíduos exercitam controle pessoal sobre as tarefas que têm a cumprir; responsabilidade, o grau de autoridade investido em um indivíduo para administrar a conclusão de uma tarefa e melhorar os processos existentes; variedade; identidade, referindose à internalização por um indivíduo da sua tarefa; e "feedback", referindo-se a mecanismos existentes para informar às pessoas os seus níveis de performance na tarefa.

5-Fatores Ambientais - observações a respeito da influência dos fatores ambientais na adoção tecnológica são relativamente freqüentes. Heterogeneidade, referindo-se à similaridade com entidades ambientais e diversidade dos clientes com as quais uma organização deve interagir; incerteza, a variabilidade do ambiente organizacional (instabilidade e turbulência); competição, relacionada à capacidade ambiental (escassez de recursos) e densidade populacional; concentração/dispersão de recursos no ambiente; e dependência interorganizacional, o grau em que uma organização compartilha idéias e recursos com outras organizações.

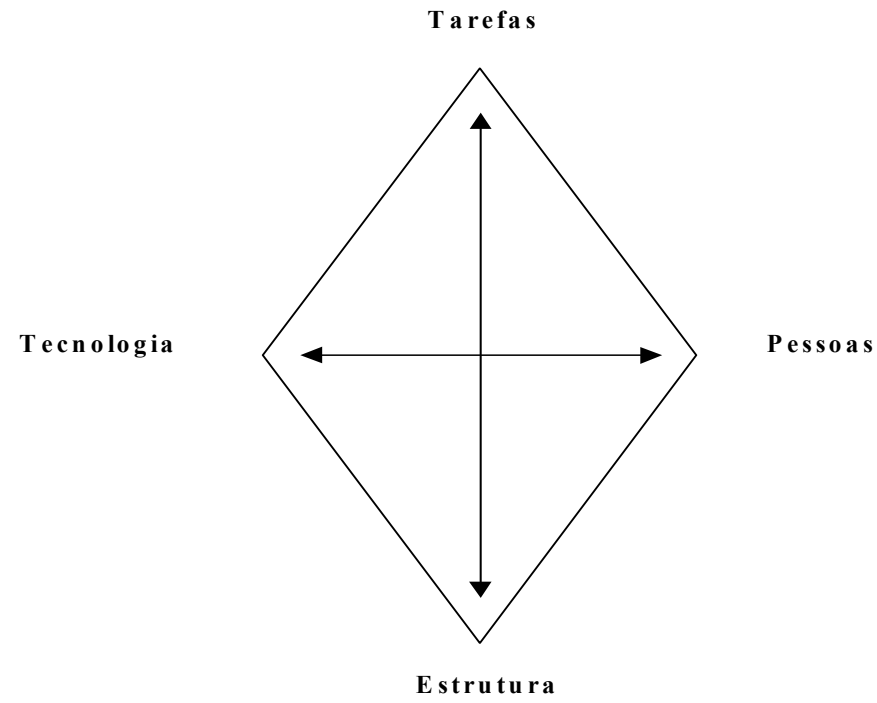

FIGURA 07 - O relacionamento entre tecnologia, pessoas, tarefas e estrutura (Leavitt, 1965) 
A tabela a seguir apresenta os fatores que influenciam a inovação tecnológica e sua associação com cada estágio do processo de inovação, conforme relatado por Kwon e Zmud (1987) a partir de estudos empíricos e não-empíricos. Eles mostram a influência relatada em cada estágio, e se esta influência está descrita como positiva ou negativamente relacionada à inovação.

Pardo (1998) apud Cunha (2000) escreve sobre a redução de riscos nos usos inovadores de TI no setor público e propõe um modelo multidisciplinar para entendimento do processo de inovação. Comprometimento, motivação, liderança e monitoramento do ambiente estão entre os comportamentos individuais mais críticos que levam a sucesso na implementação de inovações (ver Quadro 03).

\begin{tabular}{|c|c|}
\hline \multicolumn{2}{|l|}{ 01-Iniciando uma inovação: } \\
\hline Comprometimento & $\begin{array}{l}\text { Inovação em organizações públicas parecem ser dirigidas por } \\
\text { indivíduos que têm grande comprometimento com os serviços } \\
\text { que são responsáveis por fornecer. }\end{array}$ \\
\hline Abertura & $\begin{array}{l}\text { Inovação requer estar aberto a novas idéias vindas de várias } \\
\text { perspectivas. }\end{array}$ \\
\hline Liberdade & $\begin{array}{l}\text { Inovação é alavancada pela liberdade para tentar novas } \\
\text { abordagens. }\end{array}$ \\
\hline Construção de alianças & $\begin{array}{l}\text { Tal como na inovação da iniciativa privada, novas abordagens no } \\
\text { setor público usualmente necessitam de alianças para fazê-las } \\
\text { acontecer. O ambiente aberto do setor público, muitas vezes } \\
\text { caótico, aumenta a importância e o desafio de construir tais } \\
\text { alianças. }\end{array}$ \\
\hline $\begin{array}{l}\text { Liderança individual vs. } \\
\text { Patrocinador }\end{array}$ & $\begin{array}{l}\text { Inovação é encorajada pelo patrocínio de líderes que sabem como } \\
\text { articular a visão organizacional, criar uma cultura organizacional } \\
\text { aberta a novas idéias, facilitar liberdade individual para tentar } \\
\text { novas abordagens, perdoar falhas, criar os mecanismos de } \\
\text { investimento que ajudarão a transformar idéias em ações e prover } \\
\text { suporte para a implementação. Liderança individual não está } \\
\text { limitada ao nível executivo, mas pode vir de indivíduos } \\
\text { comprometidos com sua profissão e responsabilidades. Também } \\
\text { podem tomar uma diretiva gerencial e transformá-la numa visão } \\
\text { organizacional e ação efetiva. }\end{array}$ \\
\hline \multicolumn{2}{|c|}{ 02-Desenvolvendo uma inovação: } \\
\hline Comprometimento & $\begin{array}{l}\text { Inovação em organizações públicas parecem ser dirigidas por } \\
\text { indivíduos que têm grande comprometimento com os serviços } \\
\text { que são responsáveis por fornecer }\end{array}$ \\
\hline Alinhamento com objetivos & $\begin{array}{l}\text { As equipes de projeto devem estabelecer alinhamento com as } \\
\text { várias categorias de objetivos que afetam as iniciativas de } \\
\text { inovação. Isto está relacionado a vários fatores que incluem a } \\
\text { expectativa de impacto futuro dos Sistemas de Informação na } \\
\text { organização e o comprometimento dos indivíduos na tradução de } \\
\text { diretivas individuais em inovações que servem a objetivos } \\
\text { organizacionais. }\end{array}$ \\
\hline Técnicas de visualização & $\begin{array}{l}\text { Tornar metas e objetivos explícitos com o uso de suporte visual e } \\
\text { representações gráficas capacita as equipes a testar o }\end{array}$ \\
\hline
\end{tabular}




\begin{tabular}{|l|l|}
\hline & $\begin{array}{l}\text { entendimento de expectativas e objetivos usados na condução das } \\
\text { iniciativas de inovação. }\end{array}$ \\
\hline $\begin{array}{l}\text { Conhecimento da cultura } \\
\text { operativa }\end{array}$ & $\begin{array}{l}\text { Adotar uma abordagem que seja apropriada à cultura operativa, } \\
\text { ao invés do que se acredita que é ou do que popularmente é } \\
\text { apresentado como sendo a cultura do órgão, pode melhorar o } \\
\text { tempo gasto em projetos pela diminuição de esforço investido em } \\
\text { procedimentos irrelevantes. Planejar as iniciativas de inovação de } \\
\text { acordo com a cultura da organização. }\end{array}$ \\
\hline $\begin{array}{l}\text { Expansão incremental e } \\
\text { funcional dos grupos } \\
\text { participantes }\end{array}$ & $\begin{array}{l}\text { As equipes de projeto devem estabelecer planos práticos de } \\
\text { desenvolvimento de uma inovação. Isto é feito com mais sucesso } \\
\text { com um grupo central de participantes, usuários e corpo técnico. } \\
\text { Quando a inovação se desenvolve, o grupo pode crescer. } \\
\text { Contudo, a expansão na participação deve ser baseada numa } \\
\text { expectativa de benefícios realista a atingir com essa participação. }\end{array}$ \\
\hline $\begin{array}{l}\text { Abordagem interativa de } \\
\text { desenvolvimento utilizando } \\
\text { protótipos }\end{array}$ & $\begin{array}{l}\text { A equipe de projeto deve estabelecer uma visão central para o } \\
\text { protótipo. Isto é feito com mais sucesso com um grupo central de } \\
\text { participantes, usuários e corpo técnico. Quando o protótipo se } \\
\text { desenvolve, o grupo pode crescer. Contudo, a expansão na } \\
\text { participação deve ser baseada numa expectativa de benefícios } \\
\text { realista a atingir com essa participação. }\end{array}$ \\
\hline Recursos relevantes & $\begin{array}{l}\text { Ter recursos à mão que são relevantes para a tarefa é crítico para } \\
\text { o desenvolvimento da inovação. Estes recursos não estão } \\
\text { limitados àqueles disponibilizados pela organização para a } \\
\text { inovação, mas podem ser disponibilizados por fontes extra- } \\
\text { organizacionais, como por exemplo recursos pessoais. }\end{array}$ \\
\hline
\end{tabular}

QUADRO 03 - Conceitos críticos para inovação (Pardo, 1998)

O alinhamento do desenvolvimento de inovações, especificamente de sistemas de informação, com os objetivos organizacionais é um tema explorado por vários autores. Pardo (1998) apud Cunha (2000) afirma que o alinhamento com os objetivos organizacionais é necessário para a tomada de decisão e coordenação dos esforços nas equipes de projeto. Nos casos que seu trabalho estudou, sete projetos de construção de páginas de instituições públicas, havia um objetivo no nível executivo de estabelecer uma presença na Internet, mas não de quais serviços deveriam ser disponibilizados pelo site. A autora afirma que isto pode ser conseguido a partir da equipe de projeto, eles podem alinhar seus esforços de inovação com os objetivos da organização. No entanto, mesmo que não parta do nível executivo o esforço de alinhamento dos objetivos organizacionais com o processo de inovação, a falta desse envolvimento pode pôr o projeto em risco por falta de recursos ou do suporte que se faz necessário.

Albertin (2000), tal como a maioria dos envolvidos com tecnologia, acredita que uma tecnologia por si só não cria vantagens, precisa ser integrada a uma organização, com os aspectos de relacionamento de mudanças relacionados à resistência das pessoas a novos conceitos e idéias. A Figura 08 apresenta os componentes de uma organização, segundo Bloch, Pigneur e Segev (1996 apud Albertin 2000). 


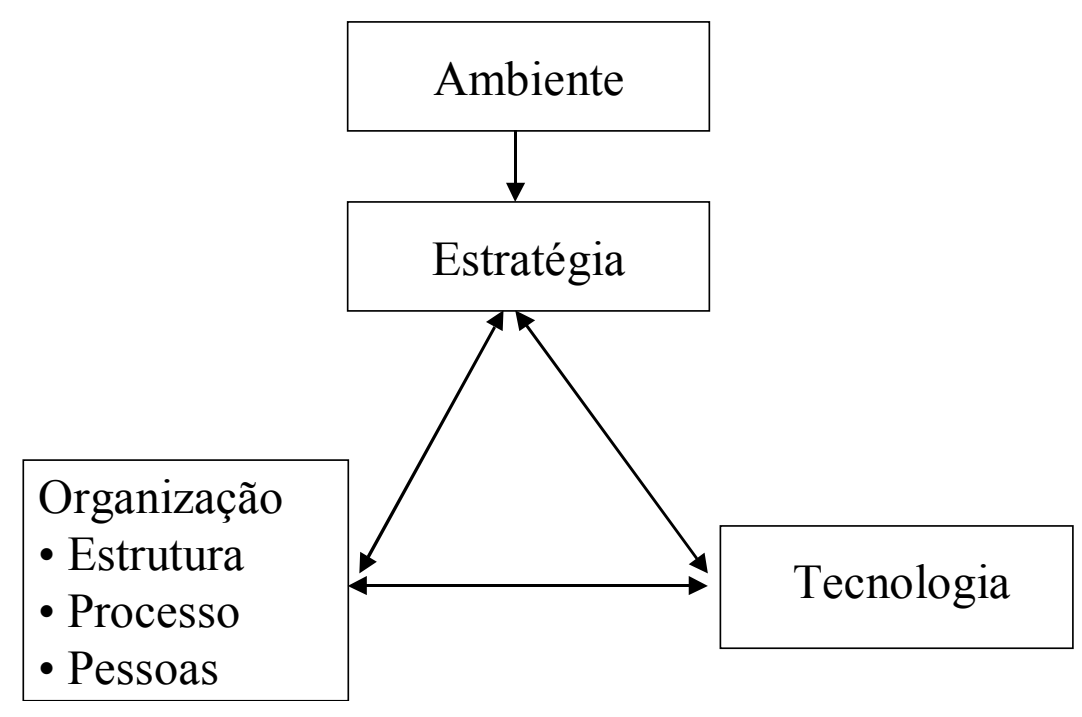

FIGURA 08 - Alinhamento dos componentes de uma organização (Bloch, Pigneur e Segev, 1996)

Os aspectos de alinhamento e equilíbrio relevantes para "Comércio Eletrônico"são: Entre estratégia e tecnologia (pela necessidade de redefinir alguns processos após a introdução de tecnologia ou utilizando a tecnologia para permitir um redesenho dos processos); Entre tecnologia e processos organizacionais e; Entre tecnologia e pessoas.

Existem duas maneiras de se considerar o alinhamento entre a tecnologia e os processos de negócio. A primeira é a necessidade de redefinir alguns processos após a introdução de sistemas de comércio eletrônico, de modo que esses sistemas se tornem completamente integrados à maneira na qual a organização realiza seus negócios. A outra forma de alinhamento de processos e tecnologia é utilizar a tecnologia para permitir um redesenho de processos, reduzindo o custo, o tempo e o número de erros associados ao processo, enquanto eleva o nível de serviço.

Os aspectos de implementação de tecnologia em uma organização podem ser resumidos em três categorias principais - o alinhamento estratégico, a adaptação da organização e a adaptação da área de TI Interna (Albertin, 2000).

Segundo o estudo de Cunha (2000), os portais de serviços públicos e de informação foram implementados com alinhamento estratégico entre o governo e a estrutura de informática, obtido, ou pela participação do dirigente na equipe de governo, ou pelo conhecimento do líder de projeto dos objetivos de governo e dos mecanismos para viabilizar a inovação. Em relação aos portais implantados em 1995, o federal e estadual, houve coincidência de disponibilidade de tecnologia com a entrada de novos governos, recém-eleitos, que modificaram as estruturas existentes. 
Os projetos dos portais ganham o comprometimento e motivação da equipe técnica. A tecnologia é nova e há liberdade para tentativas e abordagens de implementação diferentes das tradicionais. A natureza do conteúdo das páginas e a diversidade de serviços exige a criação de equipes multidisciplinares, é exigido na equipe conhecimento técnico em design e comunicação. O líder da equipe deve ter conhecimento e experiência na área pública, com habilidades de projeto, e políticas, para garantia de trânsito nas estruturas de governo.

A integração dos serviços deve ser negociada no nível estratégico do governo. A integração de dados e processos pode ser preparada no nível técnico, mas a alteração de forças que a integração e a disponibilidade de informações provoca exigem negociação política. Apesar de medidas quantitativas que confirmem esta afirmação não terem sido tomadas no trabalho, os processos de atendimento que foram revistos e reprojetados com o uso de TI, perseguindo as necessidades de integração, trouxeram para administração pública a percepção de maiores ganhos obtidos e de maior adesão pelo cidadão (Cunha, 2000). 


\section{4-Modelo Conceitual de Pesquisa}

Para melhor organizar e facilitar o desenvolvimento da pesquisa foi elaborado um modelo conceitual de referência, com suas principais características descritas no Quadro 04 a seguir:

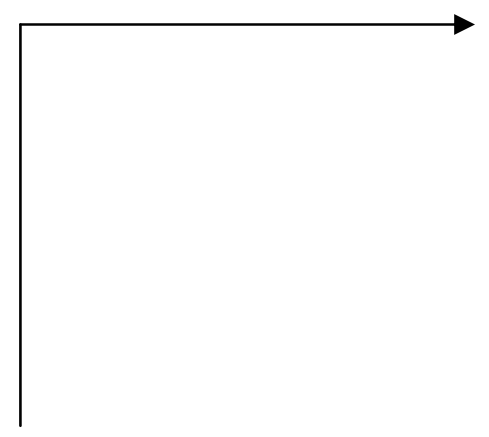

Contexto do Projeto: características gerais, motivação e patrocínio

Objeto da pesquisa: Implementação de Projetos de Modernização Administrativa Municipal suportados pela TI

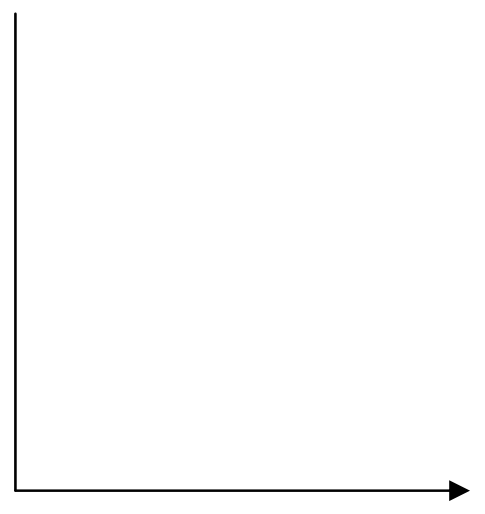

Fatores relacionados com PESSOAS: recursos humanos e ambiente

Fatores relacionados com PRODUTO: produto final, relacionamento com o cliente e tecnologia aplicada

Fatores relacionados com PROCESSO: eficiência, controle e comunicação

Fatores relacionados com

PROJETO: estratégia, e planejamento

Fatores vinculados a Implementação de TI na Administração Pública

QUADRO 04 - Modelo conceitual da pesquisa

Para montagem do modelo conceitual foi utilizado como suporte inicial o trabalho de Pressman (2002) que relata o espectro de gestão de projetos de sistemas de informação, de forma complementar foram inseridas as contribuições de diversos autores presentes na revisão bibliográfica.

Inicialmente se busca entender o contexto geral de cada projeto-alvo da pesquisa, explorando itens como características básicas, histórico, motivação e patrocinador.

Em seguida detalhamos a visão dos respondentes de cada projeto-alvo sobre o caráter facilitador ou dificultador de diversos aspectos técnico-administrativos relacionados a cada uma das quatro 
categorias fundamentais do modelo: Pessoas, Produto, Processo e Projeto.

A categoria Pessoas abrange os diversos aspectos técnico-administrativos relacionados aos recursos humanos e ao ambiente de cada projeto-alvo, destacam-se variáveis como: recrutamento, seleção e treinamento de pessoal; grau de competência dos líderes e autoridade disponível para desenvolver suas responsabilidades; impacto dos fatores externos organizacionais ou ambientais; e entendimento das necessidades dos clientes;

A categoria Produto abrange os diversos aspectos técnico-administrativos relacionados ao produto final, ao relacionamento com o cliente e a tecnologia empregados em cada projeto-alvo, destacam-se variáveis como importância e urgência do projeto; comunicação e venda do projeto ao cliente final; definição de escopo e mudança das necessidades do negócio.

A categoria Processo abrange os diversos aspectos técnico-administrativos relacionados a eficiência, ao controle e a comunicação adotados em cada projeto-alvo, destacam-se variáveis como monitoração e feedback; planos e cronogramas; solução de problemas e gerência de mudanças.

A categoria Projeto abrange os diversos aspectos técnico-administrativos relacionados a estratégia e ao planejamento utilizados em cada projeto-alvo, destacam-se variáveis como missão do projeto; apoio da alta gerência; poder e aspectos políticos e obtenção do patrocínio.

Baseado no trabalho de Netto (2000) e com o objetivo de melhor ajustar o modelo de pesquisa, foram incluídos alguns aspectos específicos de vital importância na administração pública moderna, como utilização de consultoria externa, implantação de novos produtos e infra-estrutura tecnológica existente nos projetos-alvo.

Os respondentes da pesquisa são gerentes de projeto que coordenam a implementação dos sistemas e processos relacionados a modernização administrativa nas prefeituras de São Paulo e Santo André. O modelo referência busca revelar esta percepção de forma estruturada para posterior análise e discussão comparativa.

Variáveis e fatores relevantes da implementação de projetos de TI

Busca-se neste item apresentar um conjunto sustentado de perspectivas, variáveis e fatores condicionantes específicos para execução de projetos de TI, o que se mostra fundamental para viabilizar e conduzir o processo de implementação do "Governo Eletrônico" nas administrações tributárias brasileiras. 
Conforme relatado por Albertin (2001), os esforços organizacionais para a assimilação e utilização de TI são realizados na forma de projetos de TI. Esta resposta à necessidade da organização possui como características: existência de um objetivo predeterminado, com qualidade, prazo, orçamento, condições ambientais e satisfação dos envolvidos, incertezas, complexidades e urgências.

E mais, a situação ideal é quando a organização tem um planejamento estratégico formal e conhecido, e todas as estratégias e prioridades são decorrentes dele, incluindo as de TI. Porém, muitas organizações não tem este planejamento, ou não está atualizado e adequadamente divulgado, que cria um desafio adicional para a administração de TI. Muitas vezes, as áreas responsáveis por esta função tendem a assumir as definições necessárias, elevando o risco da falta de alinhamento estratégico.

A utilização de TI significa uma mudança, muitas vezes profunda, na organização, que deve ser planejada e preparada para que se garanta seu sucesso. A falta de entendimento do processo de intervenção, por parte de expressivo número de líderes organizacionais, tem sido considerada como uma das principais causas de fracassos em tentativas de mudanças organizacionais. Albertin (2001) relata que a TI ofecere às organizações sua contribuição operacional e estratégica em duas dimensões: Funcionalidade atual (a redução do nível de qualidade dos serviços e produtos de TI atuais causa grande impacto nas empresas) e Novas funcionalidades (o fracasso, total ou parcial, de um projeto de TI que tem como objetivo disponibilizar um novo produto ou serviço de TI para a organização provoca grande impacto nelas).

Conforme Sbragia e Robic (1995), uma das questões mais freqüentemente levantadas tem se situado em torno dos critérios de avaliação e dos fatores condicionantes do sucesso/insucesso de projetos de informatização. Observações e relatos de casos reais mostram que inúmeros projetos de sistemas são percebidos como fracassos, apesar de terem sido completados dentro do prazo e do orçamento e terem atendido todas as especificações técnicas previamente estabelecidas. Da mesma forma, outros projetos são considerados sucessos, mesmo tendo falhado no cumprimento de tais itens.

Neste caso, a avaliação do sucesso se refere à verificação dos resultados e impactos obtidos pelo projeto, face às expectativas existentes quando a sua concepção, dentro de um enfoque, portanto, "expost-facto".

Na conceituação de sucesso de projetos, cabe considerar, inicialmente, o conceito de Fatores Críticos de Sucesso - FCS, definidos por Rockart (1979). Tais fatores referem-se ao limitado número de áreas onde os resultados do projeto, se forem satisfatórios, assegurarão uma contribuição relevante para o desempenho competitivo da organização. Segundo o autor, estes são os poucos fatores onde "as coisas precisam ir bem", pois se os resultados destes fatores não forem adequados, os esforços da 
organização, no período, estarão abaixo do desejado. No caso da avaliação de projetos de informática, utiliza-se o conceito de FCS para auxiliar na escolha dos critérios de avaliação do sucesso dos projetos, bem como de seus fatores condicionantes. Adicionalmente, deve-se considerar que tais fatores podem variar de projeto para projeto, assim como podem ser estabelecidos a priori, no início de cada projeto.

Para se avaliar o sucesso de projetos, Pinto \& Slevin (1988) consideram dois focos distintos: o projeto ou o produto em si e a sua implementação. No que se refere ao projeto, os seguintes fatores são considerados para se avaliar seu êxito: Tempo; Custo; Desempenho Técnico. No que se refere ao cliente ou beneficiários diretos dos resultados do projeto, os seguintes fatores são levados em consideração: Uso; Satisfação; Efetividade.

Segundo Pinto e Slevin (1988) os fatores críticos para o sucesso de projetos baseam-se nas seguintes características:

- Aderência ao Orçamento - O projeto que não for adequado ao seu orçamento original ou ao seu orçamento aprovado por todas as partes envolvidas, resultante de uma mudança, muito provavelmente irá invalidar a decisão que levou à sua aprovação, ou seja, não deveria ter sido aprovado e realizado.

- Aderência ao Cronograma - O projeto que não for desenvolvido de acordo com o seu cronograma muito provavelmente não trará as contribuições esperadas para o aproveitamento de uma oportunidade e para a solução de um problema.

- Nível de Desempenho Atingido - O projeto deve atender ao nível de desempenho esperado e acertado entre as partes envolvidas, uma vez que a decisão que elevou à sua aprovação e o orçamento correspondente assim previam.

- Validade Técnica - O projeto deve ter as soluções e qualidades técnicas nas suas atividades e produtos, aderentes a necessidades de suas especificações.

- Validade Organizacional - O projeto deve contribuir direta e indiretamente com a organização, além de não comprometer os outros componentes e aspectos do ambiente onde ele é desenvolvido.

- Efetividade Organizacional - Os resultados e produtos do projeto devem ser efetivamente utilizados pela organização, garantindo a sua contribuição.

Os autores identificaram e utilizaram em seus estudos os seguintes fatores críticos:

01-Missão do Projeto: definição e clareza inicial dos objetivos, metas e direções gerais.

02-Apoio da Alta Gerência: disposição da alta gerência em prover os recursos e autoridade/poder necessários para o sucesso do projeto. 
03-Plano e Cronogramas do Projeto: uma especificação detalhada das etapas individuais de ação requerida para a implementação do projeto.

04-Consulta ao Cliente: comunicação, consulta e consideração ativa de todas as partes afetadas pelo projeto.

05-Pessoal: recrutamento, seleção e treinamento do pessoal necessário para a equipe de projeto.

06-Tarefas Técnicas: disponibilidade da tecnologia e especialização requeridas para completar as etapas de ação técnicas.

07-Aceitação do Cliente: o ato de vender o projeto final para os usuários finais.

08-Monitoração e "feedback": obtenção e disponibilização em tempo das informações de controle para cada fase no processo de implementação.

09-Comunicação: obtenção e disponibilização de uma rede apropriada e dos dados necessários para todos os fatores-chave na implementação do projeto.

10-Solução de Problemas: habilidade de tratar crises inesperadas e desvios em relação aos planos.

Além desses dez fatores críticos de sucesso, os autores incluíram outros quatro, baseados em entrevistas e pesquisas realizadas sobre controle de projetos. Esses quatro fatores são:

11-Características do Líder de Equipe de Projeto: competência administrativa, interpessoal e técnica do líder de projeto e a quantidade de autoridade disponível para desenvolver suas responsabilidades.

12-Poder e Aspectos Políticos: grau de atividade política na organização e percepção do projeto, assim como nos próprios interesses dos membros da organização.

13-Eventos Ambientais: os impactos positivos e negativos dos fatores externos organizacionais ou ambientais nas operações da equipe de projeto.

14-Urgência: a percepção da importância do projeto ou da necessidade de implementá-lo o mais rapidamente possível.

Pinto e Slevin (1988) pesquisaram sua distribuição no ciclo de vida de projetos, apresentando a seguinte estrutura em etapas sucessivas:

口 Fatores Permanentes: Pessoal, Monitoração e feedback, Comunicação, Poder e aspectos políticos, Eventos ambientais.

- Fase Conceituação: Missão do projeto, Consulta ao cliente.

- Fase Estruturação: Apoio da alta gerência, Aceitação do cliente, Urgência.

- Fase Execução: Missão do projeto, Características do líder da equipe do projeto, Solução de problemas, Planos e cronogramas de projeto, Tarefas técnicas, Consulta ao cliente.

Fase Terminal: Missão do projeto, Tarefas técnicas, Consulta ao cliente. 
Enquanto fatores que influenciam o sucesso de projetos, DeCotiis \& Dyer (1979) e Baker \& outros (1974) definem doze condicionantes. São eles:

- Suporte da Gerência.

- Relações intra-organizações.

- Relações com o agente financiador (cliente).

- Gerência de transferência.

- Planejamento e estabilidade das especificações e projetos.

- Relações do gerente com o líder funcional de projetos.

- Clareza do papel do líder de projeto.

- Cooperação e habilidades dos membros de projetos.

- Comunicação, tomada de decisão e utilização de pessoal.

- Planejamento e cronograma.

- $\quad$ Procedimentos de controle.

- Liderança.

Robic e Sbragia (1995) apresentam 21 fatores condicionantes considerados relevantes enquanto elementos que influenciam o desempenho de projetos de informatização:

- Apoio da Alta Administração (empresa projetista): importância dada ao projeto, disponibilidade de pessoal, recursos, envolvimento da alta gerência nas decisões do projeto.

- Minimização das dificuldades no início do Projeto: data de início dos trabalhos, divulgação às pessoas envolvidas, preparo da infra-estrutura .

- Conhecimento do Negócio do cliente: conhecimento teórico/prático do tipo de trabalho do cliente em questões e variáveis envolvidas .

- Especificações e Detalhamento de sistemas: documentação dos requisitos/especificações dos usuários, especificações dadas pelo usuário, critérios de avaliação de fornecedores de software e hardware, verificação dos produtos adquiridos .

- Planejamento e Cronograma: refere-se ao grau em que os objetivos do projeto são detalhados em tarefas, são definidos os critérios de sucesso, são definidos os responsáveis pelas tarefas e são definidos os procedimentos para acompanhar as tarefas .

- Planejamento, Previsão de soluções alternativas e Estabilidade das especificações e projeto: refere-se ao grau em que soluções alternativas para solução de problemas são previstas, grau em que as especificações e o processo de projeto são planejados e claramente estabelecidos antes das diversas fases do projeto e a extensão em que eles são modificados com o desenrolar do projeto .

- Procedimento de Controle Administrativo de projeto: refere-se ao grau de utilização de 
técnicas formais de controle, tais como orçamentos, tabelas, cronogramas, bem como o grau de importância atribuído ao não cumprimento de orçamento e prazos .

- Procedimento de Controle e Verificação do produto versus Especificações: controle de documentação, atualização de versões dos desenhos de projeto, remoção de versões obsoletas, análise e aprovação de alterações e modificações, procedimentos para investigar.

- Procedimento e Metodologia de desenvolvimento de Sistemas: padronização de rotinas e estrutura de programas, identificação de versão do sistema e dos programas, planos de testes dos programas e do sistema .

- Procedimento e Metodologia de desenvolvimento de Projeto: grau de utilização de metodologia de desenvolvimento de projetos .

- Gerência de Transferência: refere-se ao processo de transferência do produto ao cliente, incluindo aspectos tais como treinamento, estabelecimento de procedimentos para execução de assistência técnica, materiais e manuais de usuários amigáveis .

- Clareza das Responsabilidades do líder e do projeto: refere-se ao grau de definição e clareza das responsabilidades e autoridade do líder e grau de controle em que o gerente de projeto exerce sobre o pessoal de projeto .

- Liderança: inclui o conhecimento e competências do líder para tomar decisões, resolver problemas e conflitos, comunicação de informações .

- Comprometimento do Gerente de projeto: refere-se ao grau em que gerente de projeto está comprometido com o cronograma, orçamento e metas de desempenho .

- Comunicação, Decisão e utilização de Pessoal: refere-se às operações internas do projeto, com particular ênfase no fluxo de comunicação, natureza das interações entre as divisões envolvidas, métodos utilizados para decisões críticas, forma como o pessoal de projeto é utilizado .

- Participação da equipe de projeto na elaboração de Cronogramas e Orçamentos: grau em que a equipe de projeto está comprometida com as metas, planejamento e cronograma do projeto .

- Cooperação entre os membros do projeto: grau em que os membros da equipe do projeto colaboram entre si na resolução de problemas técnicos e administrativos, nível de conflitos, etc .

- Capacidade Técnica: capacidade técnica dos membros da equipe de projeto, identificação de necessidades de treinamento e providências .

- Relações entre Grupos: refere-se à natureza das relações técnicas, organizacionais e pessoais entre equipe de projeto, cliente e outros grupos .

- Apoio do Cliente: refere-se ao grau de suporte e assistência dado ao projeto pelo cliente, comprometimento do cliente com as metas/cronograma/orçamento do projeto .

- Assistência Técnica e acompanhamento Pós-Implantação: execução dos procedimentos de 
assistência técnica, qualidade das atividades de suporte, rapidez no atendimento .

Algumas importantes conclusões do trabalho desses autores:

1-Os três critérios mais importantes de avaliação do desempenho de projetos de informatização parecem ser a satisfação do cliente, a qualidade técnica e a validade organizacional (adequação do projeto às necessidade do usuário).

2-Considerando-se uma avaliação global e subjetiva de sucesso feita pelos gerentes, os projetos tidos como sucesso se diferenciam dos tidos como insucesso por apresentarem: maior viabilidade de aplicação comercial, maior satisfação do cliente e maior observância a prazos e custos.

3-Os três principais fatores que concorrem para o desempenho bem sucedido dos projetos de informatização, parecem ser: o comprometimento do gerente com o projeto em si, a capacidade técnica da equipe e o conhecimento do negócio do cliente.

Albertin (2001) realizou um estudo multicasos no segundo semestre de 1999 com 99 empresas distribuídas por setores: Banco (12\%), Comércio (6\%), Indústria (43\%) e Serviços (39\%). Os casos estudados avaliaram os fatores críticos de sucesso de projetos de TI, segundo a importância de cada um deles, utilizando os 14 fatores apontados por Pinto e Slevin (1988).

Constatou-se que a visão da empresas está focada principalmente em três fatores mais citados pelos respondentes: apoio da alta gerência, qualidade das tarefas técnicas e acompanhamento e controle. O fator Apoio da alta gerência foi tido como o mais importante, permitindo concluir que as empresas dos vários setores consideram que, para o sucesso dos projetos de TI, precisam do envolvimento e comprometimento da alta gerência durante todo o ciclo de vida dos projetos. A indicação de Qualidade das tarefas técnicas e Acompanhamento e controle, permite concluir que a importância dos projetos de TI reside, principalmente, na fase de execução dos projetos.

Fatores específicos da administração pública de TI

Conforme trabalho de pesquisa realizado por Netto (2000), que enfatiza um caso recente de aplicação da TI no serviço público, o do PFE - Posto Fiscal Eletrônico da Secretaria da Fazenda do estado de SP, apresenta-se um rol de elementos propulsores e inibidores na adoção de uma solução informatizada na administração pública direta brasileira.

Entendido como instrumento básico no novo modelo de atendimento ao usuário de serviços públicos, o PFE possibilitaria a substituição da burocracia, no seu sentido negativo, pela automatização de procedimentos aliada ao ganho de controles eficazes. Segundo os entrevistados, a Sefaz-SP sempre possuiu produtos de qualidade, bons trabalhos e boas idéias, nas suas mais diversas áreas. Porém, seu 
grande pecado se constituiu na restrição do seu acesso e na sua precária divulgação para outros setores e principalmente para o cidadão paulista. O conhecimento adquirido pelos órgãos não era compartilhado.

Uma das dificuldades que a administração pública enfrenta é a falta de competitividade, uma vez que muitos de seus serviços não possuem concorrência, devido à competências específicas de governo. Este fato, conhecido e estudado, pode provocar o comodismo, o costume da ineficiência e, em situações bem desgastadas, a oportunidade de ilícitos administrativos e crimes contra o erário.

A concepção e implantação do PFE possibilitou a percepção de alguns elementos inibidores do uso de soluções informatizadas na modernização da Sefaz-SP, identificados pelos dirigentes do programa de modernização, e relatados nos documentos e relatórios de projeto, bem como destacados nas entrevistas realizadas com autoridades envolvidas com o programa:

A-Tempo exíguo entre a aprovação e a implantação do programa de modernização: a expectativa gerada pela formulação de uma solução inovadora e sua plena realização faz com que os projetos de modernização sofram da necessidade de mostrar resultados imediatos, sob pena de mais uma vez o descrédito se apoderar dos funcionários. Na iniciativa pública este fator se configura de maneira mais intensa;

B-Mudança no comando e descrédito dos funcionários: tendo vivido um período recente de estruturação, com poucas ações de porte implementadas, o programa de modernização, além do descrédito dos funcionários na sua real concretização, ao sofrer uma mudança radical na sua equipe de comando, oriunda de algumas promoções de funcionários, dificulta muito as ações iniciais desta nova fase;

C-Corporativismo e desconfiança das lideranças: A gestão e partilha do conhecimento geraria desconforto e principalmente preocupação pela perda de atribuições e funções de alguns órgãos, com algumas reações corporativas incisivas e danosas ao processo de modernização. Entre estas destaca-se a inveja daqueles que por muito tempo estiveram na direção de órgãos e obtiveram resultados pífios; e o surgimento do "engenheiro de obras prontas", ou seja, a agregação de pessoal ao projeto quando da concretização de resultados positivos e sua interferência prejudicial em questões secundárias;

D-Infra-estrutura necessária: algumas premissas estruturais eram necessárias ao empreendimento tornando-o dependente de ações pretéritas. Cientes de que não se poderia exigir dos usuários de serviços públicos o uso da Internet, necessário seria garantir o acesso à Internet em todos os pontos físicos de atendimento ao cidadão, incluindo-se aí a capacitação material e pessoal dos funcionários envolvidos. Assim, ao público seria disponibilizado um serviço padronizado, independentemente do conhecimento ou das posses do cidadão, por vezes desconhecedor dessa tecnologia moderna;

E-Montagem de equipe de manutenção e transferência de tecnologia: conseqüência do 
descrédito geral e requisito de sucesso do projeto, a formação de uma equipe de manutenção do programa de modernização constituiu-se num desafio. Nos órgãos de fiscalização da administração pública existe uma dificuldade histórica no recrutamento de funcionários para o desempenho de funções administrativas, com causas que vão desde a falta de uma política de promoção e reconhecimento eficiente até à remuneração menor. Aliado a isso, com a utilização de novas tecnologias, como fazer com que a equipe pudesse absorver toda a novidade sem decréscimo da qualidade, simultaneamente ao aumento da carga de trabalho dos desenvolvedores?

F-Divulgação deficiente: Como fator de sucesso, o programa de modernização necessita de divulgação adequada: existe a ansiedade do cidadão por novidades na área social, uma vez que órgãos fazendários não se configuram em notícia de primeira necessidade. Existe ainda a resistência e insistência da própria imprensa em destacar o que não funciona no governo, com menor proporção na divulgação daquilo que potencialmente proporciona melhoria. Existe o mito de que tudo que vem da iniciativa privada é bom e o que vem da pública é ruim, ainda arraigado à cultura brasileira;

G-Desconhecimento de experiência similar no Brasil e exterior: diferentemente de projetos baseados em experiências nacionais e estrangeiras, pelos quais se pode analisar erros e acertos, ou se fazer adaptações e ajustes, talvez não exista qualquer exemplo similar no qual o projeto possa se basear, ou simplesmente, não "sair do zero".

H-Capacitação e treinamento do corpo funcional em curto espaço de tempo: como objetivo do próprio projeto de modernização, esta mudança visa resgatar décadas de atraso tecnológico o que gera preocupação nas bases do funcionalismo. Se faz necessário não restringir o processo de capacitação e treinamento dos servidores às funções operacionais das soluções informatizadas, mas também executar treinamento gerencial e comportamental necessário ao comprometimento de todos e ao sucesso de todo o programa de modernização;

I-Restrições ditadas pela legislação: as mudanças freqüentes e as limitações impostas pela legislação e pelas regras de negócio cerceam algumas inovações e ações direcionadas à modernização, impedindo algumas facilidades aos contribuintes de tributos no cumprimento de obrigações.

Os entrevistados, bem como os documentos de projeto citados identificaram como propulsores da adoção de soluções informatizadas os seguintes elementos:

A-Aprovação por órgãos internacionais e pelo público externo: as apresentações do projeto e de seus produtos normalmente são recebidas com o apoio explícito dos contribuintes, ansiosos pela otimização dos serviços prestados pelas unidades de atendimento ao cidadãocontribuinte;

B-Caráter inovador e pioneiro: fator motivacional da equipe de projeto, o desafio do "novo" 
exige mais tempo em pesquisas e estudos, fazendo com que cada avanço ou cada barreira suplantada se torne motivo de comemoração, em momentos críticos da implantação do programa, tornando o grupo mais unido e o projeto mais transparente a todos. $\mathrm{O}$ comprometimento com o ideal de procurar quebrar o paradigma da ineficiência dos órgãos públicos também deve ser considerado;

C-Criatividade e combate ao imobilismo: contrário ao imobilismo e à adoção de fórmulas repetidas e anacrônicas, a criação do projeto de modernização e sua concretização exige esforço das lideranças e um exercício constante de adaptações e reformulações;

D-Produtos disponibilizados vão suplantando a resistência política: são motivos de quebra de resistências políticas internas dos órgãos públicos, devido à credibilidade e confiabilidade gerada pelos novos produtos;

E-Conhecimento do negócio pela equipe de projeto: constituiu-se em fator fundamental. Nas discussões e questionamentos, oriundos das mais diversas áreas, a equipe de projeto deve demonstrar conhecimento do negócio e do projeto de modernização. Este conhecimento é adquirido em anos de trabalho, no atendimento ao público interno e externo, posto que os membros de projeto, por sua origem da base, devem conhecer de perto os problemas administrativos e respectivas propostas de solução;

F-Contratação de consultores externos: especialistas em TI: os órgãos públicos tradicionalmente não dispõem em seus quadros de pessoal capacitado a desempenhar determinadas funções, tais como o desenvolvimento de grandes sistemas informatizados com tecnologia de ponta;

G-Sinergia entre equipes: a sintonia e o comprometimento criado entre a equipe de projeto, conhecedora do negócio, e a equipe de consultores e especialistas, conhecedora de novas ferramentas gerenciais e de TI, faz com que o projeto seja concretizado em tempo hábil e de acordo com o desejo da organização. Algumas experiências mal sucedidas em órgãos públicos tiveram como motivo principal a falta desse entrosamento;

H-Cobrança da sociedade: a maior conscientização da população e o poder de reivindicação de órgãos representativos fazem com que aumente a pressão externa pela prestação de melhores serviços, por parte do setor público. Fatores como a globalização; a gestão pela excelência nas empresas, com ênfase no foco no cliente; a criação e difusão dos órgãos de proteção ao consumidor; a revigoração do papel social do Estado; entre outros, destacam a insatisfação do cidadão com os serviços colocados à sua disposição, e exigem da administração pública maior transparência na sua gestão;

I-Apoio da alta administração: a sensibilização dos altos dirigentes com as demandas, principalmente com a insatisfação da sociedade com os serviços prestados pelos órgãos públicos, e o real empenho na mudança, se constituem em aspectos imprescindíveis ao sucesso dos planos de modernização e à implantação de soluções com o uso da TI. 
Conforme Reinhard (1993), na administração pública de Tl é fundamental serem consideradas múltiplas dimensões, entre elas: tecnologia e ambiente externo, estrutura e aprendizagem organizacional, distribuição de poder e papel estratégico dos sistemas de informações. A partir destas perspectivas é possível identificar fatores críticos de sucesso específicos, fazer inferências sobre a viabilidade de novos sistemas e definir estratégias apropriadas para administração local de $\mathrm{Tl}$ e coordenação central.

A turbulência do ambiente governo nem sempre é compatível com os longos prazos de maturação de projetos de sistemas e esta situação coloca problemas significativos para a administração de projetos pois estes devem ser adaptados às realidades política e administrativa. $\mathrm{O}$ fator critico de sucesso da TI pública é a competência gerencial: a administração dos órgãos precisa reconhecer o papel estratégico da TI, obter os recursos e estabelecer vínculos adequados com a função de informática. Outro desafio para os administradores públicos de TI é conseguirem ser eficientes em ambientes fortemente regulados, que podem priorizar a atenção às normas sobre desempenho. Também são críticos para a administração de Tl no governo, a competência política e o comportamento oportunístico, sem perder a visão estratégica necessária para construir operações de TI eficazes no longo prazo (Reinhard, 1993).

John Reel apud Pressman (2002) apresenta dez indicadores que verificam se um projeto de sistemas de informações estaria comprometido: 01-O pessoal de software não entende as necessidade de seus clientes; 02-O escopo do produto está mal definido; 03-As modificações são mal gerenciadas; 04-A tecnologia escolhida sofre modificações; 05-As necessidade do negócio modificam-se (ou estão maldefinidas); 06-Os prazos são irreais; 07-Os usuários são resistentes; 08-O patrocínio é perdido (ou nunca foi obtido adequadamente); 09-A equipe de projeto não tem pessoal com as aptidões adequadas e; 10-Gerentes e profissionais evitam as melhores práticas e lições adquiridas.

De modo a contornar estes obstáculos, sugere ainda uma abordagem de bom senso, de cinco partes, para projetos de software:

01-Comece com o pé direito: isso é conseguido trabalhando muito duro para entender o problema que precisa ser resolvido e depois estabelecendo objetivos e expectativas realísticas para todos os que estão envoldidos no projeto. Isso é reforçado pela estruturação correta da equipe e pela atribuição da autonomia, autoridade e tecnologia necessárias para conduzir o trabalho.

02-Mantenha a energia de momento: muitos projetos partem de um bom princípio e depois lentamente se desintegram. Para conservar a energia de movimento, o gerente de projeto providenciaria incentivos para reduzir a rotatividade de pessoal ao mínimo absoluto, a equipe 
deve enfatizar a qualidade em toda tarefa que executa e a alta gerência fazer tudo o que for possível para não ficar no caminho da equipe.

03-Acompanhe o progresso: para um projeto de software, o progresso é acompanhado à medida que produtos do trabalho são produzido e aprovados (usando revisões técnicas formais) como parte da atividade de garantia de qualidade.

04-Tome decisões adequadas: essencialmente, as decisões do gerente de projeto e da equipe de software devem ser "manter a coisa simples". Sempre que possível decida pelo software comercial em uso ou componentes de software existentes, decida evitar interfaces sob medida, quando abordagens padrão estão disponíveis, decida identificar e depois evitar riscos óbvios, e decida atribuir mais tempo para tarefas complexas ou arriscadas.

05-Faça uma análise "a posteriori": estabeleça um mecanismo consistente para extrair as lições aprendidas com cada projeto. Avalie os cronogramas planejados e cumpridos, colete e analise métricas de projeto de software, obtenha realimentação dos membros da equipe e dos clientes, e registre as descobertas por escrito.

Já Seybold (2000) apresenta 08 fatores críticos de sucesso específicos para comércio via Internet: 1Enfocar os clientes certos; 2-Dominar a experiência completa do cliente; 3-Agilizar os processos de negócio que influenciam o cliente; 4-Prover uma visão completa do relacionamento com o cliente; 5Permitir que os clientes ajudem a si próprios; 6-Ajudar os clientes a fazer seu trabalho; 7-Prestar um serviço personalizado; 8-Fomentar a comunidade.

\section{Modelo lógico de aplicação proposto por Netto (2000)}

Uma vez elencados os elementos propulsores e inibidores do uso de soluções informatizadas na esfera pública, torna-se necessário organizá-los e classificá-los a fim de possibilitar sua utilização em experiências semelhantes e à formulação de sugestões para novas pesquisas. Para isso, foi criado um modelo lógico de aplicação, onde são estabelecidos vínculos e identificados relacionamentos entre estes elementos.

Obedecendo-se critérios de afinidade e de influência direta ou recíproca, os elementos podem ser classificados segundo pontos de análise, como por exemplo, o tecnológico ou o cultural. A partir daí, são estabelecidos vínculos entre os elementos e o respectivo ponto de análise, para num próximo passo, se verificar a possibilidade de relacionamento entre eles, ou seja, seu grau de influência. A representação gráfica deste modelo lógico, ora formulado, encontra-se na Figura 09. Este modelo está baseado em conceitos de bancos de dados relacionais e sua modelagem.

Na Figura 09, os retângulos representam as classes. Assim, o retângulo superior direito indica a classe ponto de análise. O retângulo superior esquerdo indica o elemento que influencia a adoção de 
soluções informatizadas e está vinculado numa relação de um (1) para M. Ou seja, M elementos estão vinculados a apenas um ponto de análise. Neste modelo, um elemento não pertence a mais de um ponto de análise. E o losango azul entre eles indica a condição de vinculação. Os outros dois retângulos inferiores representam a especialização do elemento, ou seja, sua condição propulsora ou inibidora. O triângulo cinza representa esta especialização.

O losango amarelo indica o relacionamento ou as interferências entre os elementos. Assim, um elemento propulsor pode influenciar um inibidor ou outro propulsor, e um elemento inibidor pode interferir num propulsor ou em outro inibidor. Conforme representação do modelo lógico, um (1) elemento pode se relacionar com outros $\mathrm{P}$ elementos e $\mathrm{N}$ elementos podem interferir em um (1) elemento, independente de sua especialização propulsora ou inibidora. Um elemento origem pode se relacionar com vários elementos de destino e um elemento de destino pode interferir em vários outros de origem.

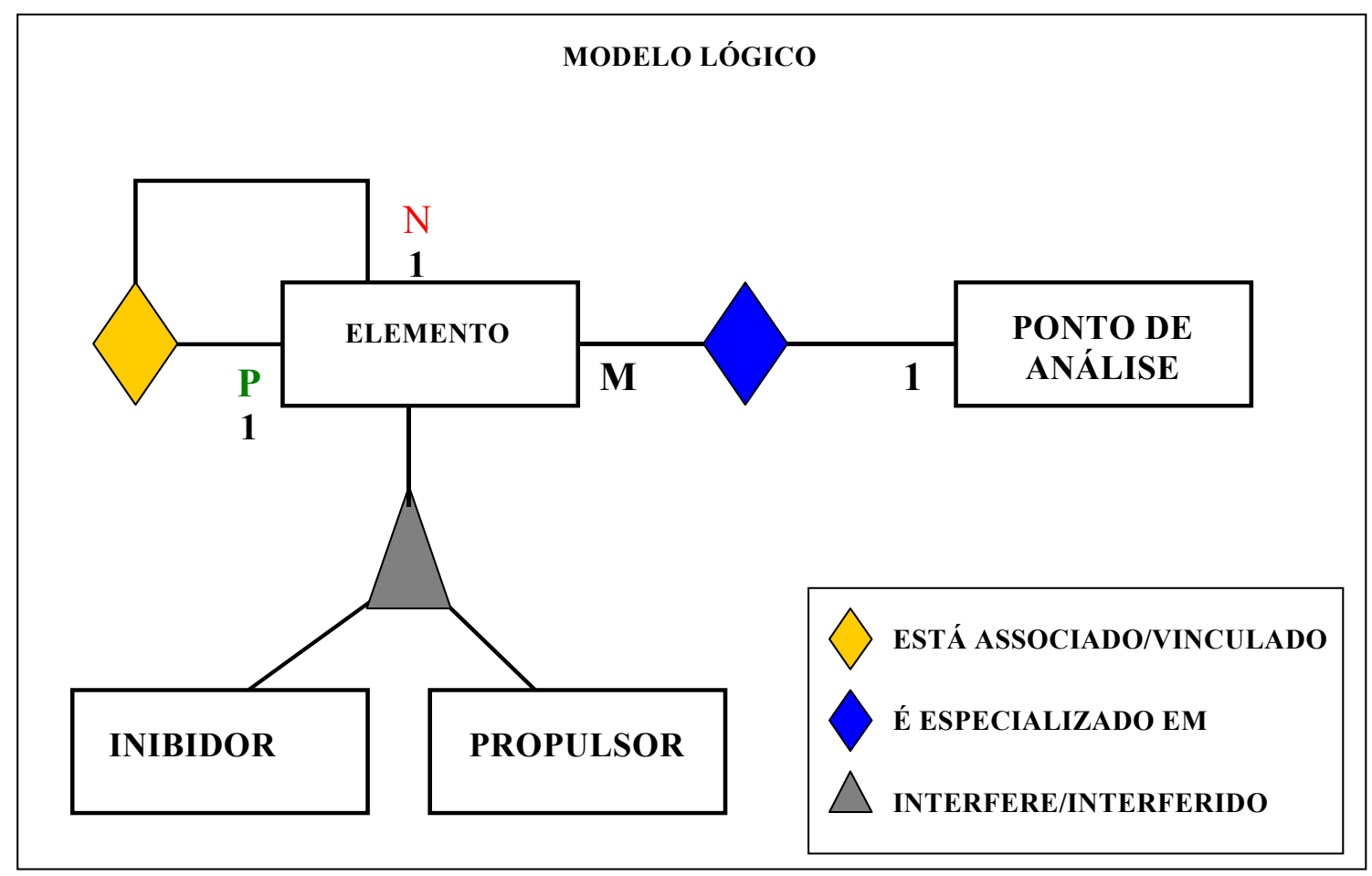

FIGURA 09 - Modelo lógico de aplicação de Netto (2000).

Exemplo do uso do modelo lógico de aplicação de Netto (2000)

A fim de provar que o modelo lógico representa a realidade dos fatos, foi utilizado, a título de exemplo, o ponto de análise Tecnológico. Nesse ponto de análise foram identificados dois vínculos com elementos propulsores e um com elemento inibidor, respectivamente: contratação de consultorias externas - especialistas em TI; implantação de produtos com o uso da TI; e ausência de infraestrutura de informática. Assim sendo, dos 18 elementos inibidores e propulsores já apresentados, três guardam primordialmente características ligadas à tecnologia, e portanto, foram classificados e 
vinculados ao ponto de análise mencionado.

Após a vinculação, o próximo passo foi verificar o possível relacionamento entre eles, ou seja, identificar influências. Constatou-se, então, que a contratação de especialistas em TI influencia diretamente a infra-estrutura da TI de uma organização, uma vez que são eles que, na prática, definem o ambiente e as necessidades tecnológicas para o bom funcionamento dos produtos que ela deverá suportar. Muitas vezes, a criação de uma área específica de TI, diferentemente dos antigos e impenetráveis CPDs - Centros de Processamento de Dados, pode ser impulsionada por esta mão-deobra especializada externa e de caráter temporário. Desta forma, um elemento propulsor pode atenuar os efeitos de um elemento inibidor.

A implantação de novos produtos também tem seu efeito catalisador incentivado pela contratação de especialistas em TI, já que o próprio órgão público, reconhecidamente, não possuía, em seus quadros, pessoal qualificado para o desenvolvimento e implantação de sistemas informatizados com tecnologia de ponta. Nesse caso, um elemento propulsor incrementa os efeitos de outro propulsor. Considerando que a implantação de novos produtos serviu para quebrar resistências e desconfianças geradas no corpo da organização, identifica-se aí a influência de um elemento propulsor pertencente ao ponto de análise Tecnológico diminuindo os efeitos sobre um elemento inibidor pertencente a um outro ponto de análise, como por exemplo, o Cultural.

Reciprocamente, o elemento inibidor ausência de infra-estrutura de informática atinge os outros dois elementos propulsores, dificultando os trabalhos dos consultores externos e a implantação de novos produtos. Assim, este elemento inibidor também pode diminuir a ação de outros propulsores ligados ao ponto de análise Tecnológico, bem como agravar as conseqüências de outro inibidor, resistência corporativa, pertencente ao ponto de análise Cultural. A partir de então, é possível construir uma verdadeira rede de influências e deixar transparente aos dirigentes dos programas de modernização, das diversas esferas de governo, quais os elementos que poderão agir positivamente ou negativamente sobre os projetos com o uso de soluções informatizadas.

\section{Condições prévias para implementar o governo digital}

Segundo backus (2001), não se pode ainda determinar todas as condições prévias para a implementação das políticas de "Governo Eletrônico". Apesar disso, pelo menos duas condições mínimas estão bem claras e devem ser observadas pelos governos que ainda não iniciaram tais políticas ou, se iniciaram sem elas, deverão sofrer as conseqüências de sua não observância.

A primeira condição parece óbvia: as políticas de "Governo Eletrônico" necessitam ser sucessoras naturais das políticas de reforma do Estado tal como foram preconizadas originalmente, no tempo em 
que ainda não era possível vislumbrar a potencialidade do instrumental da TI, e não o contrário

A segunda condição refere-se ao nível de governo alcançado pela distribuição de poder no que concerne à autonomia dos agentes e à autonomia dos governos locais para gerir sua própria máquina. Os Estados que atingiram um grau médio ou superior de descentralização e de autonomia de seus órgãos e agentes têm, certamente, melhores condições de empreender políticas de "Governo Eletrônico", de modo que o governo central deve iniciar o processo, dar as grandes diretrizes mediante um amplo programa, chamar os governos locais para a mobilização e distribuir as tarefas, sem o ônus de promover tudo.

Evidentemente essas duas condições mínimas são postas em tese, porque, como se sabe, a realidade interna dos governos é mais afeta à concorrência do que à convergência de interesses regionais e nem sempre a reforma do Estado verdadeiramente terá cumprido todos os seus desígnios iniciais, restando em partes da máquina pública uma burocracia ainda resistente às intervenções gerenciais e agressivas no que se refere à austeridade fiscal que lhe devia costurar o caminho para sempre.

As condições que levam até a governança de novo tipo, fundamental para a implementação das políticas de "Governo Eletrônico", são (Mayntz, 2001):

1. existência de uma democracia própria das formações sociais capitalistas;

2. autoridades públicas possuidoras de recursos suficientes para levar a cabo as decisões acordadas;

3. existência de uma sociedade civil forte, funcionalmente diferenciada e bem organizada.

O autor admite que essas condições são difíceis de alcançar, e somente em alguns Estados-nação democráticos altamente desenvolvidos se encontram redes de políticas, associações público-privadas e uma auto-regulação. Nesses países, a cooperação entre os atores públicos e privados não só se dá ao nível do Estado-nação; em princípio pode ter lugar em qualquer nível onde existam autoridades públicas e atores privados corporativos.

O autor destaca quatro lições sobre os casos de governo digital nos governos locais europeus:

1. o "Governo Eletrônico" somente conduzirá a uma melhoria substancial dos serviços públicos se for visto no contexto indispensável da reforma administrativa pública;

2. a difusão de pontos eletrônicos com acesso gratuito aos benefícios do "Governo Eletrônico" e a capacitação da população no uso da tecnologia é que validam os investimentos no governo via Internet;

3. O engajamento dos cidadãos mediante ferramentas eletrônicas somente tem sentido se, de fato, influenciar no real processo de tomada de decisão pelos governos locais; 
4. Dependendo da forma pela qual está regulada, é possível que a tecnologia e suas mídias juntem cidadãos ou vizinhos e fortaleçam laços sociais e o poder das comunidades locais. Também, poderão, nos bairros, contribuir para a geração de empregos e aumento da renda dos moradores.

Conclui-se que os benefícios para os cidadãos trazidos pela TI e pelas mídias não dependem desse ferramental em si, mas das condições materiais de um dado país, sobretudo, e das opções políticas e econômicas dos governos.

Desafios para implementação da Tecnologia Internet no governo

Foram investigadas por Backus (2001) experiências de diversos países e são apresentadas quatro análises SWOT com foco específico nos aspectos da presença do governo na Internet. Os SWOTs são trabalhados em um nível elevado. Entrar no detalhe seria um problema porque as situações variam para cada país, para cada momento e para cada solução.

Os aspectos políticos relacionados são por exemplo a formulação de estratégias e políticas, leis e legislação, liderança, processos de tomada de decisão, questões de financiamento, parcerias internacionais, estabilidade política (ver Quadro 05).

\begin{tabular}{|c|c|c|c|}
\hline Forças & Fraquezas & Oportunidades & Ameaças \\
\hline $\begin{array}{l}\text { Combinação com } \\
\text { reformas e } \\
\text { democratização } \\
\text { Internet como fator } \\
\text { positivo } \\
\text { Imagem de } \\
\text { modernidade }\end{array}$ & $\begin{array}{l}\text { Orçamento } \\
\text { Ausência de } \\
\text { legislação específica } \\
\text { de Internet } \\
\text { Nenhum dono do } \\
\text { problema dentro do } \\
\text { governo } \\
\text { Baixa especialização } \\
\text { em tecnologia Internet } \\
\text { Processo de tomada } \\
\text { de decisão ineficiente } \\
\text { Hierarquia acentuada } \\
\text { Curto prazo entre as } \\
\text { eleições } \\
\text { (continuidade) } \\
\text { Integração e reforma }\end{array}$ & $\begin{array}{l}\text { Aumento do } \\
\text { financiamento externo } \\
\text { Possibilidade de } \\
\text { mostrar } \\
\text { competitividade } \\
\text { Transparência causada } \\
\text { pela natural mudança } \\
\text { nos processos } \\
\text { Reinvenção do } \\
\text { governo }\end{array}$ & $\begin{array}{l}\text { Burocracia } \\
\text { Pirataria, desvios } \\
\text { Corrupção } \\
\text { Instabilidade política } \\
\text { Pouca transparência } \\
\text { Resistência }\end{array}$ \\
\hline
\end{tabular}

QUADRO 05 - Análise SWOT - Aspectos Políticos

Os aspectos sociais envolvem as pessoas, nível de instrução, emprego, renda, inclusão digital, 
ocupação urbana e rural, desigualdade social, especialização em TI (ver Quadro 06).

\begin{tabular}{|c|c|c|c|}
\hline Forças & Fraquezas & Oportunidades & Ameaças \\
\hline $\begin{array}{l}\text { Pessoas dispostas a } \\
\text { aprender } \\
\text { Desenvolvimento das } \\
\text { pessoas possibilitando } \\
\text { exportar produtos }\end{array}$ & $\begin{array}{l}\text { Baixa nível } \\
\text { educacional: } \\
\text { necessidade de } \\
\text { treinamento } \\
\text { Pouco conhecimento } \\
\text { em TI } \\
\text { Diferenças de idiomas } \\
\text { Aceitação pública dos } \\
\text { modelos de auto- } \\
\text { serviço } \\
\text { Escassez de } \\
\text { conhecimento: } \\
\text { competição com o } \\
\text { setor privado }\end{array}$ & $\begin{array}{l}\text { Incremento do } \\
\text { emprego } \\
\text { Melhoria do sistema } \\
\text { educacional } \\
\text { Promoção da Internet } \\
\text { Trabalho estruturado }\end{array}$ & $\begin{array}{l}\text { Resistência das } \\
\text { pessoas } \\
\text { Exclusão digital } \\
\text { Privacidade } \\
\text { Perda de pessoal } \\
\text { depois do } \\
\text { treinamento em TI }\end{array}$ \\
\hline
\end{tabular}

QUADRO 06 - Análise SWOT - Aspectos sociais

Os aspectos econômicos relacionados são financiamento, redução de custos, modelos do negócio, "Comércio Eletrônico" (ver Quadro 07).

\begin{tabular}{|l|l|l|l|}
\hline \multicolumn{1}{|c|}{ Forças } & \multicolumn{1}{|c|}{ Fraquezas } & \multicolumn{1}{c|}{ Oportunidades } & \multicolumn{1}{c|}{ Ameaças } \\
\hline Financiamento & Controle do & Eficiência de custos & Corrupção \\
internacional & orçamento & Novos negócios & \\
facilitado pela busca & Investidores & Maior eficiência na & \\
da governança & & arrecadação de tributos & \\
apoiada pela Internet & & & \\
$\begin{array}{l}\text { Transparência nos } \\
\text { negócios e transações } \\
\text { (licitações via }\end{array}$ & & & \\
Internet) & & & \\
\hline
\end{tabular}

QUADRO 07 - Análise SWOT - Aspectos econômicos

Os aspectos tecnológicos já discutidos serão um problema para países em desenvolvimento. Envolvem software, hardware, infra-estrutura, telecomunicações, especialização em TI, manutenção, questões de segurança (ver Quadro 08).

\begin{tabular}{l|l|l|l} 
Forças & Fraquezas & Oportunidades & Ameaças
\end{tabular}




\begin{tabular}{|c|c|c|c|}
\hline $\begin{array}{l}\text { Tudo é novidade: } \\
\text { problemas jurídico- } \\
\text { legais } \\
\text { Possibilidade de um } \\
\text { salto de modernidade } \\
\text { com a Internet }\end{array}$ & $\begin{array}{l}\text { Poucos especialistas } \\
\text { de TI no governo } \\
\text { Altos custos da } \\
\text { Internet } \\
\text { Heterogenidade dos } \\
\text { dados }\end{array}$ & 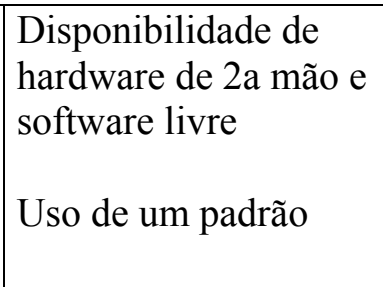 & $\begin{array}{l}\text { Dependência da } \\
\text { tecnologia }\end{array}$ \\
\hline $\begin{array}{l}\text { Estabelecimento de } \\
\text { padrões de TI }\end{array}$ & $\begin{array}{l}\text { Custos das licenças de } \\
\text { software }\end{array}$ & & \\
\hline
\end{tabular}

QUADRO 08 - Análise SWOT - Aspectos tecnológicos

Em muitos dos países existem diversos inibidores. É difícil dizer qual é o obstáculo principal porque os muitos de aspectos básicos da boa governança não estão satisfeitos ainda. Quando bem sucedidas, as iniciativas de implementação de governança via Internet otimizam as operações e serviços. Se não forem bem sucedidas, estas iniciativas podem custar milhões de dólares aos governos e uma quantidade enorme de tempo desperdiçado.

Segundo Backus (2001), os seguintes aspectos têm que ser verificados quando se examina o risco de implementar soluções de governança na Internet para países em desenvolvimento:

- Estabilidade política (eleições, democracia ou regime ditatorial).

- Nível de confiança no governo (percepção dos níveis de serviço).

- Importância da identidade do governo (fragmentação ou integração).

- Estrutura econômica (instrução, agricultura, indústria ou serviço).

- Estrutura de governo(centralizada ou descentralizada).

- Diferentes níveis de maturidade (a parte a mais fraca da corrente determina a velocidade).

- Demanda eleitoral.

O autor apresenta ainda uma estrutura de três etapas para se implementar o governo digital suportado pela TI, onde são combinados resultados de curto prazo e metas de longo prazo. Uma política de longo prazo (Visão) formulada deve estar alinhada com a implementação de curto prazo (Projetos). A relação entre a longo prazo e a curto prazo é crucial, somente se os Projetos estão alinhados, o sucesso da Visão de longo prazo poderá ser atingido. O modelo da governança apoiada pela TI apresentado, pode servir como uma referência para governos se posicionarem onde um projeto se enquadra na evolução total de uma estratégia. Uma estratégia é necessária para conseguir o objetivo desejado, ou seja, o objetivo é o nível de ambição do governo a respeito dos aspectos da democracia e dos seu negócio.

O modelo supõe que os governos definiram uma visão de TI e da política de governança na Internet, 
que descreva o nível da ambição para cada aspecto. Somente alguns países ocidentais têm uma visão desobstruída da governança suportada pela TI . A maioria de países se encontra na primeira etapa de investigar qual o nível de ambição deseja. O modelo supõe também que toda a infra-estrutura, telecomunicações e acesso necessários à Internet estão disponíveis. Esta é a situação na maioria de países ocidentais, mas nos países em desenvolvimento estes aspectos estão completamente diferentes. A estratégia deve também tratar dos condicionantes, limite e restrições. Partir dos objetivos globais para alvos concretos é um processo complexo que precisa ser feito com todos os grupos envolvidos.

Conforme Backus (2001), projetos normalmente possuem um valor estrutural para desenvolvimento quando suportados por uma visão geral e um estratégia. A empresa de consultoria Andersen definiu uma aproximação para executar projetos de governança na Internet: pense grande, comece pequeno e rapidamente ganhe escala (ver Figura 10).

Pensar grande é imprescindível para ajustar a visão e os objetivos maiores da governança. Começar pequeno é essencial para criar casos de sucesso no curto prazo e manter força direcionadora positiva, interna e externamente. Escalar rapidamente é somente possível com uma estratégia profunda que assegure todos os recursos necessários disponíveis a tempo, que os obstáculos sejam conhecidos e previamente cuidados, e que o planejamento dos projetos e suas etapas estejam alinhados com a visão e os objetivos gerais.

Implementação

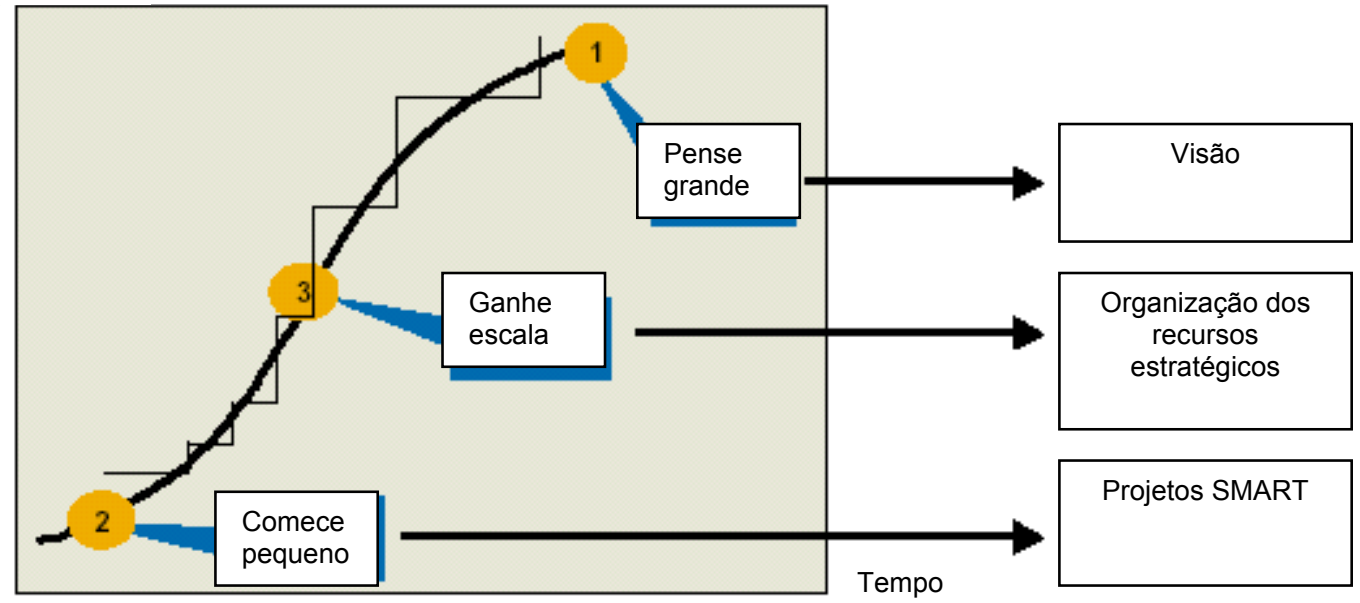

FIGURA 10 - Caminho para implementar governança apoiada pela TI (Consultoria Andersen, 2000)

O processo de visão, estratégia e execução de projetos é crucial para o sucesso da implementação. Em primeiro lugar, todos os envolvidos e interessados devem de comum acordo definir e aceitar os objetivos gerais do macro-projeto. Os objetivos devem atender as expectativas e as necessidades dos usuários finais. Na situação de construir uma casa, as necessidades do proprietário da casa 
determinam aspectos tais como o tamanho, o custo, o número das janelas e a posição da casa. Definir projetos deve ser a etapa seguinte; cada projeto deve contribuir para o objetivo final. Finalmente a estratégia determina aspectos tais como o planejamento da construção, restrições, condicionantes e limitações. Uma boa estratégia permite que os objetivos de cada projeto contribuam para atingimento do objetivo total.

1-VISÃO (Política de longo prazo para governo digital suportado pela TI): antes de iniciar os projetos, é necessária uma visão de comum acordo. Qual objetivo de ser que deve ser conseguido com a execução da governança na Internet ? Qual é o foco principal: satisfação de cliente, eficiência interna, aumento da democracia ? Na mudança para construção de uma casa as seguintes perguntas são aplicáveis: O que se quer construir? E por que? Para quem se está construindo a casa ? Quais são suas necessidades? Quais benefícios terão nossos grupos-alvo ? Ver Quadro 09 a seguir.

\begin{tabular}{|l|l|l|}
\hline \multicolumn{1}{|c|}{ O que ? } & \multicolumn{1}{|c|}{ Quem ? } & \multicolumn{1}{|c|}{ Processo } \\
\hline $\begin{array}{l}\text { Missão para posicionar o } \\
\text { governo sobre o conceito de } \\
\text { governança apoiada pela TI } \\
\text { via Internet }\end{array}$ & $\begin{array}{l}\text { Responsáveis políticos e } \\
\text { patrocinadores }\end{array}$ & $\begin{array}{l}\text { Workshops e documentos } \\
\text { relacionados a visão de longo } \\
\text { prazo }\end{array}$ \\
$\begin{array}{l}\text { Nível de Ambição do } \\
\text { programa a ser implementado } \\
\text { diretor }\end{array}$ & $\begin{array}{l}\text { Time de coordenação e } \\
\text { execução do projeto }\end{array}$ & $\begin{array}{l}\text { Pesquisa sobre as } \\
\text { necessidades dos grupos } \\
\text { envolvidos }\end{array}$ \\
$\begin{array}{l}\text { Objetivos internos e externos } \\
\text { de longo prazo }\end{array}$ & Consultores e especialistas \\
Orçamento total & & \\
\hline
\end{tabular}

QUADRO 09 - Implementando o governo suportado pela TI - Fase 01 - VISÃO (Backus, 2001)

2-ESTRATÉGIA (Arcabouço para a ação): a estratégia consiste em traduzir a visão inicial em projetos práticos. Uma boa estratégia é crucial para manter a velocidade nos processos de reforma e de execução. Por exemplo, os orçamentos devem estar disponíveis, as transformações legais devem ser iniciadas, deve-se buscar resultados rápidos e comunicar os clientes do governo. A metamorfose de construir a estratégia é o cimento entre os blocos do edifício. Depara-se então com as seguintes perguntas: Como se vai construir? O que se vai fazer primeiramente? Quem é o responsável por cada atividade? Quais aspectos legais precisam ser cobertos para construir a casa?

Porque a visão pode ser complexa e pode não ser fácil de realizar num período curto. Normalmente a estratégia consiste em diversas fases, em cada uma com seus objetivos específicos e em projetos relacionados, ver Quadro 10 a seguir. 


\begin{tabular}{|c|c|c|}
\hline O que? & Quem? & Processo \\
\hline $\begin{array}{l}\text { Objetivos político-legais } \\
\text { Objetivos sociais } \\
\text { Objetivos econômicos } \\
\text { Objetivos tecnológicos } \\
\text { Planos e cronograma } \\
\text { Organização do projeto, } \\
\text { coordenação intra-governo, } \\
\text { equipes de projeto, } \\
\text { responsabilidade e tarefas, } \\
\text { especialização } \\
\text { Condições, limites e } \\
\text { restrições político-legais, } \\
\text { sociais, econômicas e } \\
\text { tecnológicas. } \\
\text { Planos segmentados de } \\
\text { orçamento, plano de } \\
\text { comunicação e marketing, } \\
\text { parcerias }\end{array}$ & $\begin{array}{l}\text { Responsáveis políticos e } \\
\text { patrocinadores } \\
\text { Responsáveis do Comitê } \\
\text { diretor intra-governo } \\
\text { Time de coordenação e } \\
\text { execução do projeto } \\
\text { Consultores e } \\
\text { especialistas }\end{array}$ & $\begin{array}{l}\text { Avaliação } \\
\text { Análise, Seleção } \\
\text { (prioridades), Nível de } \\
\text { urgência (necessidades } \\
\text { básicas, desenvolvimento de } \\
\text { estrutura, eficiência, foco no } \\
\text { cliente) } \\
\text { Foco nas metas estratégicas } \\
\text { de longo prazo } \\
\text { Diretivas governamentais de } \\
\text { alto nível } \\
\text { Custos e benefícios } \\
\text { Impacto da democratização } \\
\text { Planos de implementação dos } \\
\text { projetos. } \\
\text { Monitoramento }\end{array}$ \\
\hline
\end{tabular}

QUADRO 10 - Implementando o governo suportado pela TI fase 02 - ESTRATÉGIA (Backus, 2001)

3-PROJETOS (Ação): projetos para implementar a tecnologia de governo via Internet devem estar alinhados com o objetivo maior da moderna governança. Para construção da casa, os projetos são os blocos que dão forma completa à visão inicial e cada projeto contribui para a realização de uma fase da estratégia definida. Em situações complexas é normal testar um projeto (em parte) por meio de um piloto. Se o piloto for bem sucedido e atingir os objetivos estabelecidos, a implementação será expandida. Se não for bem sucedido, os ajustes precisam ser feitos e a implementação deve ser cancelada. Para poder medir o sucesso de um projeto piloto é importante definir os projetos que são “SMART": simples, mensuráveis, documentados, realísticos e cronologicamente viáveis, ver Quadro 11 a seguir. 


\begin{tabular}{|c|c|c|}
\hline $\begin{array}{l}\text { Definir os objetivos SMART } \\
\text { Tipo de projeto: } \\
\text { interno/externo } \\
\text { Complexidade: fases de } 01 \text { a } \\
04\end{array}$ & 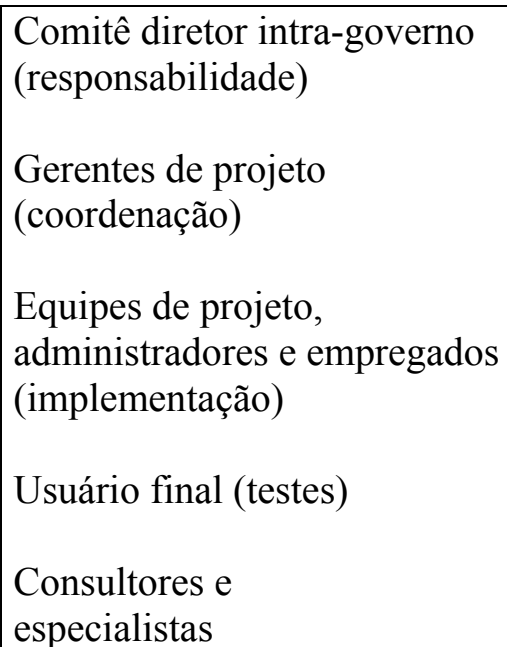 & $\begin{array}{l}\text { Sintomas -> Causas -> } \\
\text { Problemas } \\
\text { Soluções (combinação de } \\
\text { tecnologia e política) } \\
\text { Plano de implementação } \\
\text { Metas } \\
\text { Medidas } \\
\text { Equipes } \\
\text { Qualidade }\end{array}$ \\
\hline
\end{tabular}

QUADRO 11 - Implementando o governo suportado pela TI fase 03 - PROJETOS (Backus, 2001) 
3-METODOLOGIA DE PESQUISA

A pesquisa é um procedimento racional e sistemático que tem como objetivo proporcionar respostas aos problemas que são propostos e assim contribuir com o conhecimento científico. Segundo Yin, a pesquisa deve ser conduzida por um projeto de pesquisa que visa conectar os dados empíricos às questões iniciais de estudo através de uma sequência lógica que permitirá chegar às conclusões.

Este trabalho de pesquisa possui enfoque qualitativo uma vez que busca o melhor entendimento de um fenômeno específico: o processo de implementação de projetos de TI na administração tributária municipal. Alguns aspectos essenciais de estudos desse tipo são que a pesquisa qualitativa é essencialmente descritiva, ela utiliza o ambiente natural como fonte direta de dados e o pesquisador como instrumento fundamental.

Os pesquisadores qualitativos estão preocupados com o processo e não simplesmente com os resultados ou produto, eles utilizam o enfoque dedutivo na análise de seus dados. No presente estudo busca-se principalmente caracterizar e entender o processo de implementação, sendo objetivo secundário a identificação e avaliação dos resultados obtidos. A partir de um conjunto inicial de premissas se desenvolve o trabalho de campo exploratório para confirmá-las ou não, ampliando ou restringindo os pressupostos, qualificando e analisando as percepções coletadas à luz do referencial teórico adequado.

Conforme Godoy (1995b), partindo-se de questões mais amplas, que vão se tornando claras no decorrer da investigação, o estudo qualitativo pode ser conduzido através de diferentes caminhos. Existem basicamente três tipos bastante conhecidos e utilizados de pesquisa qualitativa: a pesquisa documental, a etnografia e o estudo de caso. O estudo de caso se caracteriza como um tipo de pesquisa cujo objetivo é uma unidade que será analisada de forma profunda. O propósito fundamental do estudo de caso, como tipo de pesquisa, é analisar intensivamente uma dada unidade social. $\mathrm{Na}$ presente pesquisa serão analisadas de forma profunda e sistemática as administrações tributárias dos municípios de São Paulo e Santo André.

O estudo de caso pode ser entendido como a descrição de uma situação gerencial que visa a descrição, a classificação e o desenvolvimento teórico, ou seja, seu objetivo é essencialmente a compreensão. Este e outros métodos qualitativos são úteis "quando um fenômeno é amplo e complexo, onde o corpo de conhecimentos existente é insuficiente para permitir a proposição de questões causais e quando um fenômeno não pode ser estudado fora do contexto no qual ele naturalmente ocorre" (Bonoma, 1985). 
De acordo com Yin (1989), a preferência pelo uso do Estudo de Caso deve ser dada quando do estudo de eventos contemporâneos, em situações onde os comportamentos relevantes não podem ser manipulados, mas onde é possível se fazer observações diretas e entrevistas sistemáticas. Apesar de ter pontos em comum com o método histórico, o Estudo de Caso se caracteriza pela capacidade de lidar com uma completa variedade de evidências - documentos, artefatos, entrevistas e observações. 


\section{1-O Método}

De acordo com Yin, o estudo de caso pode ser usado tanto no nível exploratório, quanto no nível descritivo e causal, indo contra o senso comum de que estudos de caso são adequados a uma fase exploratória da investigação. Para Yin, os estudos de caso podem ter quatro aplicações básicas:

- explicar as ligações causais em intervenções na vida real, que são muito complexas para os métodos quantitativos;

- descrever um contexto na vida real na qual a intervenção tenha ocorrido;

- realizar uma descrição a partir de um caso ilustrativo;

- explorar aquelas situações nas quais a intervenção avaliada não apresenta resultados perfeitamente claros para o pesquisador.

Este trabalho se utiliza do estudo de caso principalmente como aplicação para descrição de um contexto na vida real a partir de um caso ilustrativo: o processo de implementação de projetos de TI na administração tributária municipal. Busca-se explicar as ligações causais desse fenômeno e explorá-lo sistematicamente de modo a tornar claro seu entendimento.

Basicamente são três as condições que devem ser observadas para se escolher um método de pesquisa: o tipo de questão de pesquisa, o nível de controle que o investigador possui sobre os eventos a serem investigados e o nível de foco no fenômeno contemporâneo em oposição ao fenômeno histórico.

Para Yin, o estudo de caso é uma forma de fazer pesquisa social quando as questões a serem respondidas são do tipo "como" e "porquê", quando o investigador tem pouco controle sobre os eventos e quando o foco se dá sobre um fenômeno contemporâneo, dentro do contexto da vida real.

Um estudo de caso é uma forma de pesquisa social empírica que investiga um fenômeno atual dentro de seu contexto na vida real, onde as fronteiras entre o fenômeno e o contexto não estão claramente definidas e múltiplas fontes de evidência são utilizadas, encaixando-se perfeitamente como instrumento da presente pesquisa. Além disso, não há nenhum controle sobre os eventos em estudo e o foco se dá sobre o que está ocorrendo ou ocorreu recentemente. Este trabalho se utilizará de uma abordagem empírico-analítica à luz do referencial teórico adequado, optando pelo estudo de caso como sendo o método de pesquisa mais adequado.

Segundo Yin, existem cinco componentes em um estudo de caso e todos eles devem ser observados. $\mathrm{O}$ primeiro se refere às questões de estudo que devem servir para a escolha da estratégia a ser utilizada. Esta pesquisa trata de identificar e avaliar os fatores facilitadores e dificultadores de um processo de implementação, a estratégia aplicável será coletar a percepção dos responsáveis 
diretamente por meio de instrumentos como entrevistas e questionários. $\mathrm{O}$ pesquisador como participante do processo também vai contribuir com a observação pessoal e a pesquisa documental.

O segundo componente trata das proposições do estudo que servem para manter o pesquisador no caminho correto, as proposições se referem àquilo que será estudado no escopo do trabalho e ajudam o pesquisador a buscar aquilo que ele está interessado em responder. Foi estabelecido um conjunto inicial de premissas que servirá de orientador para desenvolvimento e busca à resposta da perguntaproblema.

O terceiro componente é a unidade de análise, que serve para delimitar a coleta e a análise de dados. Esta pode ser um indivíduo, um programa específico ou processo de implementação por exemplo. A unidade de análise foi definida como sendo o processo de implementação de projetos de TI na administração tributária municipal. O quarto componente faz a ligação entre os dados encontrados e as proposições feitas anteriormente. Será trabalhado no item referente a tratamento e análise dos dados, esta ligação será subsidiada por referencial teórico adequado. O quinto componente é o critério para interpretar as descobertas do estudo que não pode ser definido precisamente por não conter dados para análises estatísticas. Estes dois últimos componentes representam a análise do estudo de caso e servem de base para elaboração das conclusões. Em relação ao conjunto inicial de pressupostos, os dados coletados serão interpretados de forma comparativa-indutiva e qualificados em agrupamentos facilitadores e dificultadores do processo, de modo a organizar as explicações, inferências e conclusões obtidas.

As conclusões devem ser específicas com possíveis inferências não-estatísticas e explicações permitindo que as generalizações sejam usadas como base para novas teorias e modelos. Para determinação da unidade de análise, observa-se a natureza do estudo como global ou específica, ou seja, qual será o foco principal da análise a ser realizada (indivíduo, organização como um todo, grupo específico, etc.).

Quando se utiliza apenas uma unidade de análise, a natureza do caso é denominada global, caso se adote sub-unidades de análise o caso passa a ter natureza embutida ou específica.

Casos de natureza global devem ser considerados quando não se puder identificar sub-unidades de análise lógicas ou quando a teoria que apoia o estudo de caso possui caráter global. Porém corre-se o risco de alguns fenômenos ao nível operacional passarem desapercebidos. Já os casos de natureza específica, além de serem mais complexos, possuem o risco de que o investigador, ao se deter mais profundamente nas sub-unidades de análise, perca a visão de conjunto do caso (Yin, 1989). 
O presente estudo se utilizará de casos de natureza global, definindo-se como unidade de análise as administrações tributárias das cidades de São Paulo e Santo André. A utilização de várias subunidades de análise não seria o mais indicado, pois além da complexidade inerente, distancia-se do objetivo do trabalho: caracterizar o processo de implementação de projetos de TI para "Governo Eletrônico". Para Yin, a adoção de um caso simples é adequada para diversas circunstâncias:

1-Quando representa um caso crítico que testa uma teoria bem formulada. A teoria deve especificar um conjunto claro de proposições, assim como as circunstâncias nas quais acredita-se que as proposições sejam válidas. Para confirmar, desafiar ou estender a teoria, deve existir um caso que atenda a todas as condições para testar a teoria. $\mathrm{O}$ estudo de caso simples pode, então, ser usado para determinar se as proposições da teoria são corretas ou não, ou se existe um conjunto de alternativo de explicações mais relevante.

2-Quando o caso representa um situação única ou extrema, isto é, quando o caso é tão raro, que é difícil o estabelecimento de padrões comuns.

3-Se o caso possuir um caráter revelatório, onde o investigador tem a oportunidade de observar e analisar um fenômeno ainda não investigado cientificamente.

O estudo de caso simples ainda pode ser utilizado como um prelúdio para estudos futuros, tal como o uso de um estudo de caso como ferramenta exploratória, ou também para conduzir um estudo piloto que é o primeiro de um estudo de caso múltiplo. Entretanto, nesta última circunstância, o estudo de caso simples não pode ser considerado como um estudo completo em si.

Neste trabalho será aplicado o estudo de caso simples como ferramenta exploratória, os casos escolhidos possuem caráter revelatório e representam situações críticas para testar uma teoria bem formulada, permitindo observar e analisar com profundidade o tema da Implementação de Projetos de Modernização Administrativa Municipal suportados pela TI, fenômeno muito pouco explorado cientificamente, atual e relevante para a administração pública brasileira como um todo.

\section{Planejamento e qualidade do Estudo de Caso}

Conforme Yin (1989), o planejamento do estudo de caso simples necessita de uma investigação cuidadosa do caso em potencial para minimizar as possibilidades de pouca representatividade e para maximizar o acesso necessário à coleta das evidências. Busca-se realizar esta pesquisa por meio da reunião de evidências em fontes de dados distintas e complementares, assegurando maior representatividade e validade da investigação.

Os estudo de caso dedicam-se a estudos intensivos do passado, presente ou de interações ambientais de uma ou mais unidades sociais: indivíduo, grupo, instituição, etc. São validados pelo rigor do protocolo estabelecido, condição necessária para garantir qualidade ao estudo. Existem basicamente 
quatro critérios para avaliar a qualidade de um projeto de pesquisa em geral e de um estudo de caso em particular:

- Validade dos "constructos" - É fundamental estabelecer medidas operacionais para os conceitos que estão sendo estudados, não é indicados trabalhar com conceitos extremamente vagos, é necessário operacionalizá-los. Isto é especialmente válidos em estudos de caso, onde muitos fatores "subjetivos" podem acabar influenciando a coleta de dados. As táticas recomendadas para aumentar a validade do "constructo" são: utilizar múltiplas fontes de evidência na coleta de dados, estabelecer uma cadeia de evidências e ter informantes-chave para examinar o relatório preliminar do estudo.

- Validade interna - Segundo Yin este critério relaciona-se somente com problemas explicativos ou causais, nos quais o pesquisador está tentando estabelecer as condições em que um determinado evento conduz a outro. De uma forma geral, para os estudos de casos os problemas de validade interna podem ser relacionados aos problemas mais amplos de estabelecer inferências que ocorrem todas as vezes que um evento não pode ser diretamente observado. A utilização de múltiplas fontes de evidência neste trabalho, tem a finalidade de oferecer maiores garantias de validade interna.

- Validade externa - É necessário estabelecer até que ponto as descobertas de um estudo podem ser generalizadas para outras situações. Não se pode trabalhar, em estudos de caso, com generalizações estatísticas, já que os casos não pode ser entendidos como amostras. É preciso tentar construir uma generalização analítica baseada firmemente em uma teoria bem elaborada.

- Confiabilidade - Aqui se busca demonstrar que o estudo pode ser repetido com a obtenção dos mesmo resultados. O roteiro da pesquisa deve ser claro e detalhado para que outros pesquisadores possam repetir o estudo de caso e chegar aos mesmo resultados.

A qualidade da investigação será garantida por meio de atenta observância dos quatro critérios básicos de Yin apresentados: utilização de definições realmente operacionais, múltiplas fontes de evidência, generalização analítica baseada firmemente em teoria bem elaborada e roteiro de pesquisa claro e detalhado viabilizando repetição.

O Método do Estudo de Caso obtém evidências a partir de seis fontes de dados:

1-Documentação: a documentação, pela sua própria característica, é uma importante fonte de dados e nela as informações podem tomar diversas formas como cartas, memorandos, agendas, atas de reuniões, documentos administrativos, estudos formais, avaliações de plantas e artigos da mídia. O uso da documentação deve ser cuidadoso, pois segundo Yin (1989), eles não podem ser aceitos como registros literais e precisos dos eventos ocorridos e seu uso deve 
ser planejado para que sirva para corroborar e aumentar as evidencias vindas de outras fontes. 2-Dados Arquivados: os dados arquivados, em computador, por exemplo, podem ser relevantes para muitos estudos de caso. Estes dados podem ser (Yin, 1989) dados de serviços, como número de clientes, dados organizacionais - orçamentos, mapas e quadros - para dados geográficos, lista de nomes, dados de levantamentos, dados pessoais - como salários, listas de telefone, que podem ser usados em conjunto com outras fontes de informações tanto para verificar a exatidão como para avaliar dados de outras fontes.

3-Entrevistas: de forma geral, as entrevistas são uma fonte essencial de evidências para o estudo de Caso (Yin, 1989), uma vez que os estudos de caso em pesquisa social lidam geralmente com atividades de pessoas e grupos. O problema é que isto pode sofrer a influência dos observadores e entrevistadores e, por isto, podem ser reportadas e interpretadas de acordo com as idiossincrasias de quem faz e relata a entrevista. Por outro lado, os respondentes bem informados podem fornecer importantes "insights" sobre a situação.

4-Observação Direta: ao visitar o local de estudo, um observador preparado pode fazer observações e coletar evidências sobre o caso em estudo. "Estas evidências geralmente são úteis para prover informações adicionais sobre o tópico em estudo." (Yin, 1989)

5-Observação Participante: este é um tipo especial de observação, na qual o observador deixa de ser um membro passivo e pode assumir vários papéis na situação do caso em estudo e pode participar e influenciar nos eventos em estudo. O problema da observação participante é que ela tem grande capacidade de produzir vieses, pois o investigador pode assumir posições ou advogar contra os interesses das práticas cientificas recomendadas, pode assumir posições do grupo ou organização em estudo e pode ter problemas ao fazer anotações ou levantar questões sobre os eventos em perspectivas diferentes.

6-Artefatos Físicos: os artefatos Físicos e Culturais também se constituem em uma fonte de evidências e podem ser coletados ou observados como parte do estudo de campo e podem fornecer informações importantes sobre o caso em estudo.

Este trabalho se utilizará das seis fontes de dados para assegurar o rigor e confiabilidade do método. O pesquisador, na condição de servidor municipal da prefeitura de São Paulo desde 1999, é participante do processo de implementação objeto do estudo, o que facilita e viabiliza o acesso à esta organização bem como à prefeitura de Santo André.

$\mathrm{O}$ investigador tem que estabelecer procedimentos que visem maximizar os resultados a serem obtidos com utilização destas seis fontes de evidência. Yin (1989) recomenda a aplicação de três princípios:

口 Uso de Múltiplas Fontes de Evidência - esta é uma característica dos Estudos de Caso e o uso de múltiplas fontes de evidência pode ajudar o investigador a abordar o caso de forma mais 
ampla e completa, além de pode fazer cruzamento de informações e evidências;

- Criação de um Banco de Dados do Estudo de Caso - para se registrar todas as evidências, dados, documentos e reportes sobre o caso em estudo e para torná-los disponíveis para consultas;

- Manutenção de uma Cadeia de Evidências - que deve ser seguido para melhorar a fidedignidade do Estudo do Caso e tem como objetivo explicitar as evidências obtidas para as questões iniciais e como elas foram relacionadas às conclusões do estudo, servindo de orientação para observadores externos ou para aqueles que farão uso dos resultados do estudo.

As constatações percebidas na pesquisa empírica serão analisadas para verificar a aderência com os conceitos apresentados no referencial teórico e o conjunto inicial de pressupostos, os resultados formarão a base para um conjunto de recomendações para organizações públicas envolvidas com processos e projetos de mesma natureza.

Os estudos de casos baseiam-se nas mesmas técnicas da análise histórica, mas adicionas duas fontes de evidência não usualmente incluídas no repertório dos historiadores: observação direta e entrevista sistemática. Estas serão as duas principais fontes de evidência utilizadas neste trabalho.

A entrevista é uma das mais importantes fontes de informação em um estudo de caso e oferece ao pesquisador um grande flexibilidade na obtenção de informações. Existem várias formas de entrevista, como a não-estruturada, a estruturada e o "survey". Para Yin, a entrevista em estudos de caso pode ser: De natureza aberta-fechada, onde o pesquisador solicita aos respondentes a apresentação dos fatos bem como as opiniões a eles relacionadas; Entrevista focada, onde pode assumir uma natureza aberta-fechada ou conversacional, mas seguindo um roteiro estabelecido e; Entrevista tipo "survey", onde as questões e as respostas são mais estruturadas. 


\section{2-Organização e desenvolvimento da pesquisa}

O trabalho se inicia com ampla revisão bibliográfica para aprofundar os conhecimentos sobre o tema e identificar os aspectos do problema de pesquisa já trabalhados pela literatura. Com base nesses pontos fundamentais foi elaborado o roteiro de entrevistas, visando obter o máximo de informações possível. As entrevistas serão realizadas pelo próprio pesquisador, no sentido de esclarecer eventuais dúvidas, conduzir o processo buscando otimizar o resultado final e ratificar a validade interna do estudo de caso.

Por intermédio da aplicação dos instrumentos de pesquisa adequados ao método do estudo de caso, sustentados por um modelo conceitual de pesquisa, pode-se comparar os resultados coletados em campo com o referencial bibliográfico correspondente e a partir disso inferir correspondências, ausências e novos elementos, atingindo plenamente o objetivo do trabalho.

Baseado no modelo conceitual de pesquisa, foi aplicado um roteiro estruturado de entrevista nos órgãos de administração tributária dos municípios de São Paulo e Santo André, desenvolvendo documentação estruturada da percepção dos gerentes responsáveis pela modernização administrativa. Como documentação complementar dos casos, levanta-se outras fontes de evidência como a observação direta, focada na percepção do pesquisador.

Com o intuito de melhor qualificar o processo de implementação, além de verificar e analisar similaridades e diferenças na execução dos projetos e resultados obtidos, foram aplicadas diversas fontes de evidência complementares (ver Quadro 12).

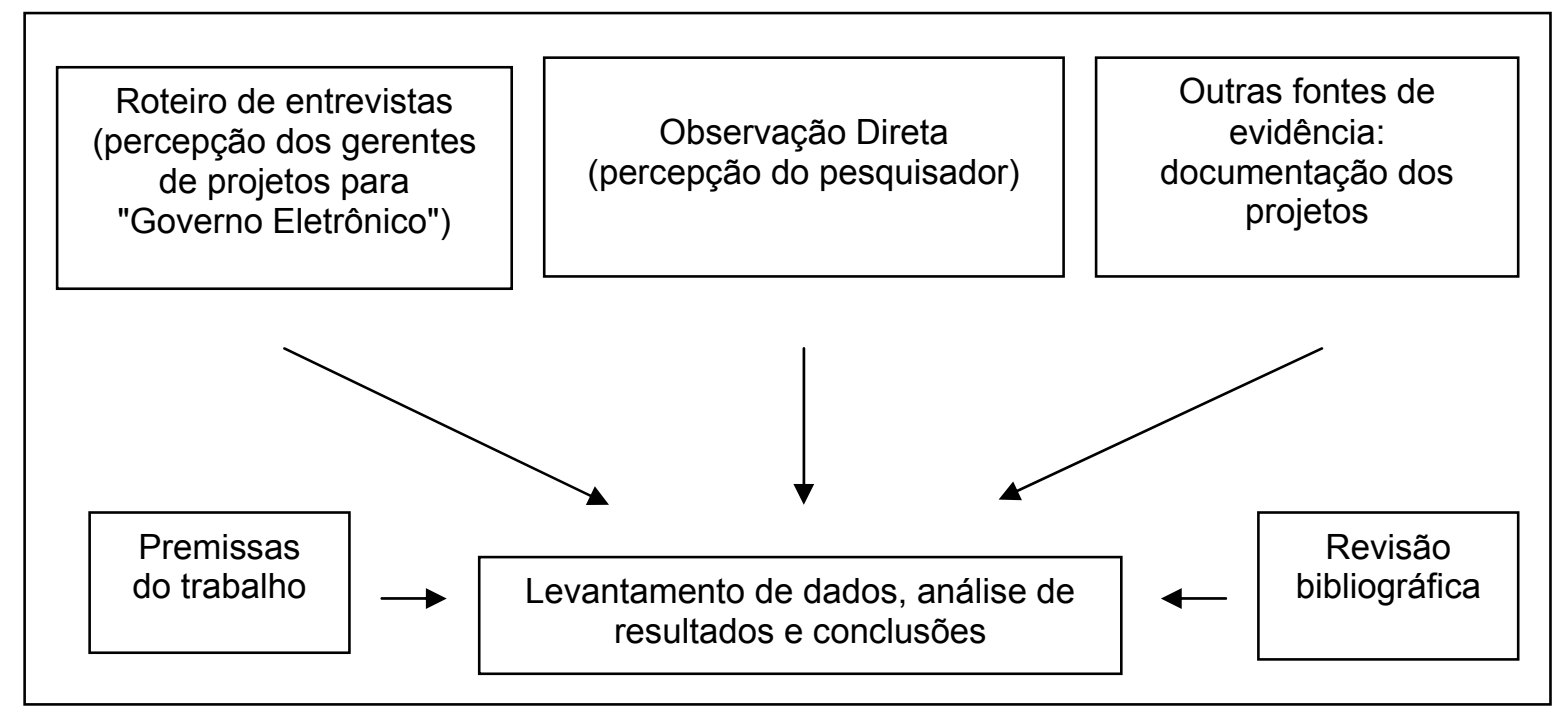

QUADRO 12 - Condições e fontes de evidência da Pesquisa

Yin (1989), apresenta duas estratégias para a análise de evidências no Estudo de Caso e que serão utilizadas neste trabalho: 
1-Confiança nas Proposições Teóricas: seguir as proposições teóricas estabelecidas no inicio do Estudo de Caso é a melhor estratégia para a análise das evidências, uma vez que os objetivos originais e o projeto da pesquisa foram estabelecidos com base nas proposições que refletem as questões da pesquisa, a revisão da literatura e novos "insights". As proposições ajudam o investigador a manter o foco e a estabelecer critérios para selecionar os dados. Ajudam também a organizar o caso e a analisar explanações alternativas.

2-Desenvolvimento da Descrição do Caso: constitui-se na elaboração de um esquema descritivo para se organizar o Estudo de Caso e pode ser usado para ajudar a identificar os tipos de eventos que podem ser quantificados e como um padrão geral de complexidade para ajudar explicar.

Para análise do caso, um dos métodos mais recomendados, segundo Yin é a comparação de padrões que consiste em comparar os padrões empíricos com os padrões previstos. Quanto maior for a coincidência entre os padrões, maior será a validade interna do estudo. Uma outra alternativa é a elaboração de explicações, que seria um tipo especial de comparação de padrões.

Para cada estudo de caso serão apresentados dados de conjuntura sócio-econômica, motivação, patrocinadores, estrutura administrativa e um relato histórico de sua implementação, incluindo alguns resultados e perspectivas, sistemas internos existentes e serviços eletrônicos disponibilizados a sociedade, além de comentários adicionais e pontos de destaque coletados. Busca-se identificar os principais fatores facilitadores e dificultadores percebidos em cada implementação e realizar uma discussão analítica para cada variável condicionante do processo, mostrando seu caratér propulsor e seu caráter inibidor, destacado pelos respondentes e pelas fontes de evidência complementares - itens 4.1 e 4.2 do capítulo 04 a seguir.

Com base em algumas referências de autores importantes, será desenvolvida uma análise comparativa simplificada entre os casos, buscando inferir algumas semelhanças e diferenças em sua condução e resultados alcançados, e apresentando forças e fraquezas componentes de uma análise tipo SWOT item 4.3 do capítulo 04 a seguir. 
4-ESTUDO DE CASOS

\title{
4.1-O CASO DA PREFEITURA DE SÃO PAULO
}

\author{
PROJETO DE MODERNIZAÇÃO DA ADMINISTRAÇÃO TRIBUTÁRIA \\ NA PREFEITURA DO MUNICÍPIO DE SÃO PAULO - PMSP
}

Primeiramente é importante se conhecer alguns dados geográficos, sociais e econômicos do município de São Paulo - ano base 2000 (Fonte - site oficial do governo de São Paulo) para contextualizar o ambiente interno e as características do cidadão-usuário dos serviços públicos.

口 Área do município $1.525,00 \mathrm{~km}^{2}$

口 Densidade demográfica $\left(\mathrm{hab} / \mathrm{km}^{2}\right) \quad 6.823,68$

口 População $\left(\mathrm{n}^{0}\right)$ 10.434.252

口 Taxa de Alfabetização (\%) 95,40

๑ Total de servidores públicos ativos: 124.924

Alguns importantes Indicadores Econômicos (Contas Municipais):

口 Valor Adicionado Fiscal (US\$) 30.100.085.826,43

口 Repasse de ICMS para o Município (US\$) 883.748.907,58

口 Repasse de IPI para o Município (US\$) 10.221.870,38

口 Repasse de Compensações Financeiras para o Município (US\$) 71.751,89

Secretaria de Finanças e Desenvolvimento Econômico

As principais atribuições da Secretaria de Finanças e Desenvolvimento Econômico da cidade de São Paulo são Lançar, fiscalizar, arrecadar e controlar os impostos e taxas municipais; Manter e atualizar os cadastros fiscais; Elaborar a Proposta Orçamentária Anual e o Plano Plurianual do Município; Acompanhar, coordenar, controlar e avaliar a execução orçamentária; Controlar a arrecadação, o movimento e a guarda do dinheiro público e títulos mobiliários; Negociar as Dívidas internas e externas do Município e ainda; Efetuar auditoria dos projetos e atividades desenvolvidas na administração direta e indireta, a escrituração e controle das contas patrimoniais e orçamentária (ver Figura 11). 
Secretaria de Finanças e

Desenvolvimento Econômico

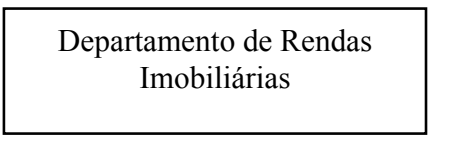

\begin{tabular}{|l|}
\hline Departamento de Auditoria \\
\hline
\end{tabular}

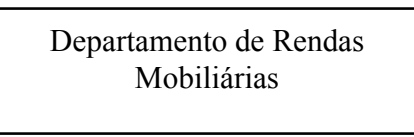

Departamento de Contadoria
Departamento do Tesouro

Supervisão Geral de Administração e Finanças

Assessorias: Controle da dívida pública, Informática, Economia e Finanças Públicas, Orçamento Municipal, Jurídica, Serviço de atendimento ao contribuinte e Imprensa.

FIGURA 11 - Organograma da Secretaria de Finanças e Desenvolvimento Econômico da PMSP

Departamento de Rendas Imobiliárias - RI

É a unidade da Secretaria responsável pela fiscalização e lançamento dos tributos incidentes sobre a propriedade imobiliária urbana: IPTU - imposto predial e territorial urbano; ITBI-IV - imposto sobre transmissão inter-vivos, a qualquer título, por ato oneroso, de bens imóveis, por natureza ou acessão física, e de direitos reais sobre imóveis, exceto os de garantia, bem como a cessão de direitos à sua aquisição e Contribuição de melhoria.

\section{Departamento de Rendas Imobiliárias - RM}

É a unidade da Secretaria responsável pela fiscalização e lançamento dos tributos incidentes sobre as atividades econômicas: ISS - imposto sobre serviços de qualquer natureza; TLIF - taxa de fiscalização, instalação e funcionamento e TFA - taxa de fiscalização de anúncios.

\section{Histórico e contexto do Projeto de Modernização}

O CMI - Conselho Municipal de Informática é o órgão normativo, elaborador e regulador da política de informática da Prefeitura Municipal de São Paulo composto por representantes dos Secretários do Governo, da Comunicação e Informação Social, do Planejamento Urbano, da Administração, das Finanças e Desenvolvimento Econômico, de Implantação das Subprefeituras bem como por representante da Companhia de Processamento de Dados do Município de São Paulo. O CMI definiu as seguintes diretrizes de TI para a PMSP: 1-Modernização de processos internos; 2-Implantação de Sistema de Gestão 3-Ampliação e otimização da rede municipal 4-Disponibilização de serviços via Internet e 5-Implantação de soluções suportadas por banco de dados relacional. 
A Prefeitura de São Paulo busca um novo padrão de gestão pública no município mais ágil, mais eficiente e comprometido com os interesses dos cidadãos. Nesse sentido, a Secretaria de Gestão Pública elaborou projetos de modernização administrativa para intensificar o uso da informática e das telecomunicações como condição necessária para transparência, eficiência e acesso; propiciar a produção e o acesso às informações; revolucionar o funcionamento da máquina pública; e implementar ações orientadas para o cidadão.

O Governo Federal tem participado de ações voltadas para a reforma do Estado, através do BNDES, tendo como instrumento o PMAT. Tal programa vem sendo desenvolvido em diversas cidades brasileiras, e será um marco na modernização da capital de São Paulo. Através dessa iniciativa , poderão ser incorporadas aos sistemas informatizados do município vários sistemas de informação e gestão, a exemplo de alguns implantados em outros estados e municípios. O PMAT é composto por uma série de ações que buscam dotar a Prefeitura paulistana de ferramentas modernas de administração de seus recursos ( tributários, humanos, financeiros e materiais ) e de tomada de decisão, orientados pelos critérios da descentralização administrativa e da transparência nas ações do Poder Público.

A modernização necessita ser acompanhada do fortalecimento da capacidade gerencial, normativa, operacional e tecnológica da administração tributária e da gestão pública dos serviços sociais básicos e demais ações da natureza fiscal, além do monitoramento e controle público dos gastos da Prefeitura, resgatando a credibilidade do Poder Público quanto ao cumprimento de suas obrigações.

No âmbito da administração financeira, através do PMAT, implantar gestão integrada dos desembolsos da Prefeitura, por intermédio de novo sistema orçamentário, financeiro e contábil, contemplando entre outras melhorias, a descentralização dos pagamentos, a eliminação de defasagens na escrituração contábil e a simplificação e uniformização da execução orçamentária , financeira e contábil na administração direta e indireta, refletindo na transparência do gasto público. A melhoria na gestão, com conseqüente redução de desperdícios, contribuirá para o incremento de recursos a serem aplicados nos setores sociais.

Dado ao porte do projeto do PMAT, sua elaboração se estendeu pelo ano de 2001 até a aprovação definitiva junto ao BNDES, celebrada pela assinatura definitiva do contrato em 15/05/2002, entre a Prefeitura do Município de São Paulo e o BNDES.

Assim sendo o projeto está em pleno desenvolvimento e realização, contando com 29 ações que envolvem diversas áreas da Administração Municipal. A prefeita Marta Suplicy anunciou em junho de 2002 a liberação de R\$ 116 milhões para modernização e informatização da administração via 
PMAT. Segundo a prefeita, $90 \%$ dos recursos são do BNDES e $10 \%$ da Prefeitura. Os recursos serão distribuídos da seguinte maneira: TI (R \$ 47,8 milhões - 41\%), Serviços técnicos especializados (R\$ 41,9 milhões - 35,9\%), Capacitação de RH (R\$ 10,1 milhões - 8,8\%), Equipamentos de Apoio (R\$ 2,6 milhões - 2,3\%) e Infra-estrutura de apoio ( $\mathrm{R} \$ 13,9$ milhões - 12\%). Trata-se do maior programa de modernização da administração tributária feito no país.

Através do PMAT, previsto para durar cerca de dois anos, se prevê um aumento anual de arrecadação na ordem de R\$ 986 milhões, que será conseguido com a modernização da coleta de impostos, taxas e da cobrança da dívida de contribuintes inadimplentes. Com o serviço, o Município conseguirá uma economia de R \$ 375 milhões, obtida com uma melhor administração de recursos humanos e folha de pagamentos, além maior controle de licitações e compras. Para que as previsões se concretizem, o programa vai adquirir 3.800 microcomputadores e 2.100 impressoras que serão utilizados no apoio à fiscalização, integração de bancos de dados em rede e atualização de cadastros. "Os problemas da Prefeitura não são apenas os buracos na rua, mas também de gerenciamento administrativo, cujos processos são muito antigos", destacou o secretário municipal João Sayad, de Finanças e Desenvolvimento Econômico.

Os principais objetivos PMAT paulistano envolvem Apoiar a modernização da administração tributária e a melhoria da qualidade do gasto público; Obtenção de mais recursos estáveis e não inflacionários e; Melhoria da qualidade e redução do custo praticado na prestação de serviços.

A seguir um resumo das principais ações do PMAT paulistano:

1-Implantação de uma nova rede de dados (revisão e racionalização de procedimentos com a introdução de ferramentas modernas de TI).

- Situação Atual: computadores de grande porte, lentos e com alto custo de manutenção.

- Situação Esperada: ambiente de computação aberto e distribuído, em plataforma baixa; baixo custo de manutenção e de treinamento; aumento da "capilarização" da rede da Prefeitura (ampliação do número de pontos da rede).

2-Modernização dos sistemas corporativos:

- Desenvolvimento de formas modernas da gestão dos recursos - tributários, humanos, financeiros e materiais.

- Novos sistemas Orçamentário, Tributário, de Gestão da Dívida Ativa, de Gestão de Recursos Humanos, de Gestão Estratégica de Suprimentos.

- Incorporação de novas funções, impensáveis na época que os antigos sistemas foram concebidos.

- Sistemas integrados, que comunicam entre si e permitem disponibilizar seus dados na 
Internet.

- Desenvolvimento e implantação de novos procedimentos e sistemas de gestão de suprimentos e de contratos. Desenvolvimento e implantação de novo sistema de gestão dos recursos humanos).

3-Implantação de um Sistema de Informações Gerenciais (SIG) e Levantamento Aéreo da Cidade:

- Implantação de um sistema de informações gerenciais que atenda aos princípios da descentralização administrativa e da transparência nas ações do Poder Público.

- Ampliação da capacidade de tomada de decisão.

- Extração e consolidação de informações dos sistemas corporativos da PMSP.

- Disponibilização aos Secretários, Chefes de Gabinete, e outros Gestores Públicos.

- Base para o georreferenciamento das informações municipais.

- Ampliação do poder de fiscalização (atualização do Cadastro Imobiliário) e de planejamento regionalizado das políticas públicas (geoprocessamento).

Custo estimado: R\$ 117 milhões (90\%: BNDES, 10\%: PMSP)

Tempo de implementação previsto: 2 anos (início em maio de 2002)

\section{Portal da Prefeitura de São Paulo}

Seus princípios básicos incluem Construir serviços a partir das escolhas dos cidadãos; Tornar o governo e seus serviços mais acessíveis à população; Facilitar a inclusão social; Prover informação de maneira responsável e Usar os recursos governamentais de maneira efetiva e eficiente.

As principais ações de Implementação foram Criação do grupo SGP On-line; Definição de conteúdos e informações para o Portal da Prefeitura; Planejamento, definição e preparação das informações e dos serviços a serem disponibilizados eletronicamente; Desenvolvimento de ferramentas de extração de dados existentes nos sistemas corporativos "legados" da Prefeitura e sua disponibilização no Portal e ainda; Disponibilização eletrônica de novos serviços, tais como: acompanhamento de licitações, banco de concursos públicos e de oportunidades de estágio, serviços para o servidor (holerite, licenças, férias etc.).

Para lidar com a crescente demanda por serviços públicos existe a necessidade da modernização da máquina administrativa municipal, através da revisão e racionalização dos procedimentos e da informatização. Busca-se a qualidade e eficiência no desenvolvimento de suas atividades, além da satisfação plena do usuário final que é o cidadão. No âmbito da Secretaria de Gestão Pública da prefeitura de São Paulo, trabalha-se na execução de uma reforma administrativa centrada em quatro dimensões principais : 
- Gestão e Governabilidade: integração horizontal e vertical da estrutura de governo, coordenação e acompanhamento da ação governamental, disponibilizar informações de forma integrada para tomada de decisão em vários níveis da ação governamental

- Prestação de Serviços e Informações: facilitar a vida do cidadão paulistano via descentralização e disponibilização eletrônica de serviços, agilização dos atendimentos (automatização e simplificação dos procedimentos) e ampliação do rol de serviços

- Mecanismos de Ação Democrática: transparência e o controle social do governo, Ouvidoria, orçamento participativo e avaliação da qualidade do serviço prestado.

- Democratização do Acesso: telecentros e programas de capacitação digital para servidores e para comunidades.

A herança do modelo organizacional vigente passa pela pouca flexibilidade da estrutura e dificuldade de adequação às demandas ou ao crescimento da cidade, alta centralização e organização setorializada que fragmenta a realidade social e urbana. Busca-se implantar um novo modelo de gestão focado em três ações fundamentais: Informatização das Secretarias e demais órgãos da prefeitura; Aperfeiçoamento da gestão de Pessoas: baseada em valorização e democratização das relações de trabalho capacitação, avaliação e maior mobilidade nas carreiras e; Descentralização Administrativa: condição necessária para a inclusão, a administração municipal precisa estar o mais próximo possível dos munícipes, estímulo ao trabalho em equipes multidisciplinares e crescente delegação de competências e recursos.

O projeto de modernização da Administração Tributária para o município como um todo abrange os seguintes aspectos fundamentais:

口 fornecer uma visão global da estrutura organizacional da unidade responsável pela administração tributária e sua integração às demais unidades administrativas;

ـ evidenciar os fluxos de informações e o funcionamento do Sistema de Informações Cadastrais e do Cadastro Técnico Imobiliário;

口 fornecer um detalhamento das atribuições da unidade responsável pelo cadastro na prefeitura apresentadas sob a forma de rotinas administrativas;

口 permitir a orientação dos servidores na execução de suas tarefas, constituindo elemento básico para o treinamento e reciclagem;

- facilitar a coordenação e o controle dos serviços internos da unidade responsável pelo cadastro;

a permitir o conhecimento do relacionamento do Sistema de Informações Cadastrais com os demais Sistemas Administrativos, assim como do Cadastro Técnico Imobiliário com outros Cadastros, especialmente o Cadastro Imobiliário Fiscal; 
- estabelecer os procedimentos de controle da arrecadação e de cobrança administrativa;

- definir a tecnologia e os procedimentos de relacionamento com os contribuintes.

O projeto PMAT-BNDES esta baseado em quatro ações principais de informatização: 1-Implantação de uma nova rede de dados; 2-Levantamento aéreo da cidade: base para o georreferenciamento das informações municipais com consequente ampliação do poder de fiscalização (atualização do cadastro imobiliário) e de planejamento regionalizado das políticas públicas (geoprocessamento); 3Construção de sistema de informações gerenciais: busca-se ampliação da capacidade de tomada de decisão através da extração e consolidação de informações dos sistemas corporativos da PMSP e; 4Modernização dos sistemas corporativos: implementação de novos sistemas Orçamentário, Tributário, de Gestão da Dívida Ativa, de Gestão de Recursos Humanos, de Gestão Estratégica de Suprimentos, plenamente integrados e seus dados na Internet .

$\mathrm{Na}$ Secretaria de Finanças e Desenvolvimento Econômico se pretende, através das diversas ações do seu projeto de governo digital sustentando pelo PMAT-BNDES, consoante a legislação vigente, uma maior justiça fiscal e, conseqüentemente, minimizar a evasão fiscal. Este objetivo maior deverá ser alcançado através dos seguintes objetivos específicos:

- fortalecimento da capacidade gerencial com redesenho dos sistemas e procedimentos internos;

口 reformulação dos sistemas de informações;

- melhoria da qualidade do atendimento ao contribuinte;

口 aprimoramento da apuração da base de cálculo dos tributos, do acompanhamento das obrigações tributárias e do controle e gerenciamento da execução do gasto público;

- adequação da legislação vigente aos avanços tecnológicos (internet e demais tecnologias de informação) e à nova ordenação jurídica (Código de Defesa do Contribuinte e reforma tributária).

A melhoria da qualidade do atendimento ao cidadão deverá ser atingida através da implantação de facilidades via Internet, como exemplos: emissão de certidão negativa de tributos imobiliários; emissão de certidão do valor venal do imóvel do exercício presente e dos anteriores;emissão de outras certidões, a partir de métodos seguros de identificação do solicitante, face ao sigilo fiscal; declaração de transação imobiliária, para fins de ITBI, inclusive com a emissão de documento de arrecadação (DAMSP ou sucessor); emissão de segundas vias de notificações, documentos de arrecadação ou certidões; atendimento de demandas do contribuinte: ingresso de pedidos, inscrição imobiliária para atualização cadastral (a partir de métodos seguros de identificação do solicitante) e SAC: informações gerais, legislação, calendário tributário, FAQ, endereços, documentos necessários, pagamento de tributos, parcelamento de débitos. 
No aspecto de atendimento ao público busca-se sistematização e informatização dos procedimentos internos; utilizar sistemas que permitam não apenas a consulta a dados cadastrais (como hoje ocorre), mas a tomada de decisão e de providências imediatas, evitando inclusive a criação de expedientes; melhoria física dos locais de atendimento através da readequação dos "layouts" e disponibilização de postos de auto-atendimento; postos de atendimento com estruturas menores, estrategicamente (física e temporalmente) localizados; totens de atendimento (telefone e/ou TAA), localizados em locais de médio afluxo; internet e facilitar ao máximo o pagamento de tributos e agilizar a baixa desses pagamentos.

Os resultados práticos esperados do Projeto estão listados a seguir: Melhoria do atendimento ao público; Redução das necessidades de deslocamento dos moradores e trabalhadores da cidade; Melhoria e simplificação dos procedimentos; Informações públicas e transparentes; Novas oportunidades para fornecedores com a melhoria das compras públicas; Aumento da arrecadação pela melhoria de sua gestão e ainda ;Melhor alocação de talentos e capacitação de servidores e servidoras (trabalhos mais ricos e menos repetitivos).

Pretende-se ainda obter benefícios como aumento da produtividade fiscal, com incremento significativo na arrecadação própria por meio de acompanhamento das obrigações tributárias, maximização do uso de recursos, melhoria das relações fisco-contribuinte, avanço na informatização da arrecadação, fiscalização, tributação e cobrança da dívida ativa, adequação da infra-estrutura e dos meios materiais, reorganização de funções, trâmites e responsabilidades, agilização da cobrança administrativa dos créditos tributários, revisão e consolidação do aparato legal vigente e atualização e ampliação das bases cadastrais existentes.

\section{Percepção dos respondentes}

Foram citados a simplificação dos procedimentos, o aumento da arrecadação pela melhoria de sua gestão e a melhoria do atendimento ao público como Motivações Iniciais do projeto.

Como Metas e Objetivos iniciais foram definidos a modernização dos processos internos e a disponibilização de serviços via Internet visando melhoria da qualidade e redução do custo praticado na prestação de serviços.

O projeto se originou na alta gerência e na oportunidade de parceria com o BNDES via programa PMAT e sua justificativa_se baseou na modernização administrativa e consequentes relações de custo/benefício para o município e seus cidadãos. O financiamento do projeto se deu com recursos próprios do município na ordem de $10 \%$ do total, complementado pela adesão ao programa PMAT do BNDES 


\section{FATORES LIGADOS A PESSOAS:}

Aspecto Recrutamento, seleção e treinamento de pessoal - Recursos Humanos

A seleção do pessoal envolvido com o projeto privilegia os recursos humanos diretamente ligados aos problemas a serem resolvidos e aos processos a serem modernizados. Para desenvolvimento de soluções para atendimento ao público participam os gerentes de atendimento, para soluções de fiscalização de tributos participam os inspetores fiscais e assim por diante, é fator facilitador envolver o usuário final na especificação da ferramenta de TI e na remodelagem dos processo de trabalho.

O treinamento busca complementar competências e nivelar o conhecimento das equipes dos subprojetos, realizando palestras de divulgação/promoção do projeto para o público interno e cursos específicos técnico-gerenciais para as equipes de implementação, fatores facilitadores que devem ser complementados com uso da Intranet e do "site" da prefeitura para informar e disseminar conceitos e andamento do projeto de modernização.

\section{Aspecto Competência dos líderes e autoridade - Recursos Humanos}

A competência e a autoridade dos líderes de projeto é natural pois são gerentes de unidades diretamente ligadas às funcionalidades dos produtos desenvolvidos e conhecedores dos processos de trabalho. Esta prática de alocar os funcionários diretamente envolvidos com os problemas é facilitadora da implementação, recomenda-se treinamentos específicos e motivação para otimizar o compromisso das equipes com as mudanças.

\section{Aspecto Aptidões do pessoal e uso de consultoria - Recursos Humanos}

Os grupos responsáveis pelos subprojetos são equipes multidisciplinares formadas por recursos internos, quando necessário se alocam consultores temporários para disseminar práticas e soluções específicas e pontuais. O uso de consultores temporários é focado na função de comprometer e disseminar conhecimentos técnicos-gerenciais necessários para os trabalhos práticos de especificação técnica e re-engenharia de processos. Não se pode abdicar de uma coordenação central que propõe padrões e cobra resultados. O uso de consultoria externa com propósito maior de treinar e ensinar melhores práticas agrega valor para a organização e facilita as implementações futuras, já que o consultor "ensina a pescar" e não simplesmente "dá o peixe".

\section{Aspecto Uso das melhores práticas e lições aprendidas - Recursos Humanos}

As melhores práticas e lições aprendidas pelas equipes de implementação são disseminadas na Intranet e devem existir reuniões periódicas de troca de experiências entre os líderes de subprojetos. A coordenação central trata de organizar as experiências de sucesso e disponibilizar para todos de forma estruturada. Outra fonte de melhores práticas advém da atuação dos consultores, otimizando os 
recursos utilizados e facilitando a implementação dos sistemas.

Aspecto Fatores externos sobre a equipe - Ambiente

Os fatores externos podem influir de forma positiva ou negativa sobre as equipes, é fundamental tratar o projeto de forma transparente e disponibilizar informação para todos os envolvidos, não dando brecha para rumores e resistências por falta de clareza na condução das mudanças. A participação do pessoal interno é incentivada ao máximo buscando comprometimento e alavancando o sentimento de participação no sucesso do projeto. Fatores como a inovação e o desafio intrínsicos a implementação um projeto de modernização servem de facilitador do processo já que mobilizam talentos internos para sua consecução.

Aspecto Percepção das necessidades dos clientes e disposição para mudanças - Ambiente É um fatores facilitador da implementação que as equipes compreendam as necessidades dos clientes, isto é conseguido através da intensa participação dos mesmos no entendimento dos problemas e no desenvolvimento das soluções. A disposição para mudanças é fator facilitador do processo uma vez que cria um clima de comprometimento e participação do corpo funcional, verdadeiros conhecedores do dia a dia da organização, de suas virtudes e defeitos, e os mais indicados para encontrar novos caminhos e realizar as mudanças. O clima favorável às mudanças é tarefa da alta gerência sendo transparente nos objetivos e priorizando as pessoas para uma implementação bem sucedida do projeto.

Aspecto Realidade político-administrativa versus Prazo de maturação do projeto - Ambiente

A realidade das prefeituras é marcada por iniciativas de curto prazo justificadas pela não-continuidade das administrações, deve-se privilegiar subprojetos que tragam alta visibilidade e resultados significativos, preferencialmente em atividades estratégicas como maior arrecadação de tributos e melhor atendimento ao contribuinte. Deste modo se consegue perpetuar o projeto por um prazo maior e realizá-lo de forma completa no longo prazo, facilitando suas implementações futuras alavancadas pelas implementações de sucesso já realizadas. Dentro da organização permanecem o sentimento de mudança e a vontade de fazer mais e melhor.

\section{FATORES LIGADOS AO PRODUTO}

Aspecto Percepção da importância do produto e da necessidade de implementação - Produto final Percebe-se como facilitador do processo a completa percepção da importância do produto e da necessidade de implementação das soluções de TI por todos os "stakeholders" de alguma forma envolvidos: clientes, público interno, média e alta gerência. A não-existência destas percepções disseminadas na organização compromete o processo. A imagem de modernidade também contribui como facilitador da implementação, pois desperta nas pessoas o espírito de participação e o interesse 
pelo novo.

Aspecto Definição do escopo do produto - Produto final

A definição do escopo do produto é definida com participação ativa dos funcionários envolvidos no processos a serem redesenhados e futuros usuários das soluções de TI a serem implementadas, ninguém melhor do que eles para propor melhores caminhos e encontrar soluções para os problemas existentes. As equipes devem contar com apoio de especialistas nas diversas disciplinas necessárias a especificação e construção dos sistemas e mudanças nas rotinas de trabalho. A existência de um escopo bem definido, detalhado e factível para a solução de TI a ser implementada é fator facilitador do processo.

\section{Aspecto Resistência dos usuários - Produto final}

A resistência dos futuros usuários internos e externos das soluções de TI e dos novos processos operacionais é fator dificultador da implementação do processo. Esta resistência pode ser superada com disponibilização gradual de serviços e alterações nas rotinas que causem maior visibilidade e agreguem bastante valor para a organização, de modo a impulsionar as equipes dos subprojetos a se espelharem nos "cases" de sucesso. Outro aspecto a ser incentivado para superar resistência é a comunicação eficiente do que realmente está acontecendo na organização, de forma ampla e transparente, incluindo os usuários na sua concepção e implementação.

Aspecto Comunicação, consulta e consideração de todas as partes afetadas pelo projeto Relacionamento com o Cliente

A eficiência do processo de construção de soluções de TI é facilitada pela comunicação e consideração do usuário como agente primordial e participante ativo da implementação. A alta direção destaca um grupo de especialistas que coordena e cobra as ações de envolvimento/participação da massa de usuários no processo de desenvolvimento.

Aspecto Venda do projeto para o usuário final - Relacionamento com o Cliente

A venda adequada do projeto para o público interno e externo é fator facilitador da implementação, uma vez que são eles que devem comprar a idéia e adotar os novos sistemas/processos no dia a dia do seu trabalho. Uma equipe de especialistas dispara uma série de iniciativas que contribuem para inserir estes usuários no projeto, provendo canais de relacionamento, disseminando informação relevante e recrutando talentos internos que possam contribuir inseridos nas equipes de implementação multidisciplinares.

Aspecto Tipo de relacionamento com o cliente - Relacionamento com o Cliente

O relacionamento com o cliente externo ou interno é gradual, trata-se de um trabalho de aculturação 
intenso e constante, onde as soluções de TI desenvolvidas vão alterando paulatinamente a velocidade e a qualidade dos serviços públicos disponibilizados ao cidadão-contribuinte. As mudanças internas normalmente são mais difíceis pois muitos funcionários se encontram desmotivados e despreparados no trato com a tecnologia ou simplesmente tem medo da mudança, insegurança e acomodação. A gerência de RH precisa realizar um enorme esforço de treinamento/divulgação do projeto de modo a engajar o corpo funcional na implementação da modernização. Uma abordagem de implementação completa e imposta de cima para baixo do uso das soluções de TI e mudança de rotinas funciona como dificultador do processo, pois fomenta a resistência interna.

\section{Aspecto Disponibilidade de tecnologia e especialização - Tecnologia}

Com a garantia dos recursos financeiros via PMAT + recursos próprios da prefeitura, aliada a compra de hardware/software/consultoria/serviços via licitações públicas bem elaboradas, dispõe-se de adequado arcabouço de tecnologia e especialização externa mobilizados para facilitar a implementação. Porém isto não basta se o pessoal interno não estiver motivado e comprometido com as mudanças, capacitado para gerenciá-las de maneira eficiente e apoiado por ações e discurso da alta gerência.

\section{Aspecto Trato da mudança de tecnologia - Tecnologia}

Deve ser realizado com visão de longo prazo e buscando otimizar a utilização dos recursos existentes, erros na escolha de tecnologia podem provocar perdas consideráveis e dificultar a implementação. Questões de mudança de tecnologia normalmente são bastante delicadas e devem ser conduzidas por pessoal experiente e com elevado nível de informação para decidir, não provocando assim dificuldades futuras ao processo de modernização.

\section{Aspecto Seleção de tecnologia e integração ao legado - Tecnologia}

Bastante pesquisa e estudo devem ser destinados a escolha dos fornecedores de produtos/serviços e principalmente definir com precisão e de forma gradual o que se quer mudar e como fazê-lo de forma eficiente. A questão da integração ao legado é de suma importância para otimizar recursos tecnológicos existentes e prover soluções diferenciadas, no menor prazo e com boa relação custobenefício para a organização. Saber escolher e utilizar a tecnologia e os serviços dos fornecedores é um ativo crítico da gerência do projeto que precisa ser desenvolvido, facilitando sobremaneira a implementação.

\section{FATORES LIGADOS AO PROCESSO}

Aspecto Modificações das regras de negócio - Eficiência

Definir as regras de negócio de maneira incompleta ou equivocada é fator dificultador da implementação bem sucedida, para minimizar estas ocorrências se utiliza metodologia apropriada 
baseada em processos da engenharia de software buscando atingimento do nível 02 do CMM "Capacity Maturity Model" para desenvolvimento interno ou exigência de fábrica de software certificada na licitação pública. A especificação técnica dos sistemas exige participação ativa do público usuário das soluções que devem ser construídas com nível de flexibilidade adequado para suportar modificações de regras previsíveis pelos analista de negócios. Práticas como estas facilitam bastante a implementação bem sucedida.

\section{Aspecto Normas versus Desempenho - Eficiência}

No setor público as normas ditam o comportamento dos agentes públicos e as rotinas das repartições, o desempenho e a qualidade dos serviços são muitas vezes limitados pela legislação e demais instrumentos normativos. Estas barreiras devem ser superadas via ações/mudanças políticoadministrativas emanadas da alta gerência do governo municipal e com apoio do legislativo, patrocinando e viabilizando o projeto de modernização a ser implementado. A elevada cobrança da sociedade e da alta gerência sobre as equipes de implementação é relativizada observando as reais limitações e recursos disponíveis para cada subprojeto. O excesso de normatização não adequada ou restritiva se torna fator dificultador do processo.

\section{Aspecto Mensuração da eficiência/eficácia - Eficiência}

O desempenho e a eficiência do projeto devem ser avaliados sem perder de vistas as condições e limitantes impostos aos gerentes de subprojetos, mensurando comparativamente situações similares e calibradas conforme a flexibilidade/autonomia de cada implementação. Práticas não adequadas de mensuração podem se transformar em fatores dificultadores do projeto de modernização, pois informam dados incorretos da situação dos trabalhos e prejudicam as decisões gerenciais que dependem delas.

\section{Aspecto Obtenção e disponibilização das informações gerenciais - Controle}

Boas práticas de obtenção e fornecimento de informações gerenciais é fator facilitador da implementação. Ferramentas e metodologias adequadas devem ser utilizadas por um grupo especializado nesta tarefa, que delegue responsabilidades, padronize rotinas e consolide os resultados de modo a disponibilizar a informação correta no momento correto para a pessoa correta, missão bastante ambiciosa e crítica para uma administração eficiente que precisa interagir com grande quantidade de fornecedores de serviços/produtos e satisfazer seus clientes internos e externos.

\section{Aspecto Tratamento das mudanças nas regras de negócio - Controle}

A gerência de mudanças prioriza as alterações que tragam maiores benefícios para a organização e suporta novos requisitos de sistema por meio de uma metodologia apropriada baseada nos processos da engenharia de software de modelos de qualidade como CMM e ISO. As mudanças nos processos 
de trabalho e regras de atuação da organização são constantes e tendem a dificultar a implementação se não houver respaldo para suportá-las com eficiência. Práticas de implementação gradual e definição de sistemas flexíveis são facilitadores do tratamento de alterações que já devem ser previstas no escopo do projeto.

\section{Aspecto Adequação dos prazos - Controle}

Os prazos são frequentemente cobrados sem muita rigidez no setor público e na área de implementação de projetos de TI, mas isto está mudando com novas formas de contratação de serviços de fábrica de software e consultoria, como por exemplo os acordos de nível de serviço que se utilizam de indicadores de prazo, custo e esforço. Novos mecanismos de planejamento e controle dos prazos são facilitadores do processo, possibilitando otimizar os recursos disponíveis e planejar com maior eficiência.

\section{Aspecto Obtenção e disponibilização dos dados e canais de comunicação - Comunicação}

A disponibilidade dos fatores-chave para implementação de um projeto é imprescindível para seu sucesso, os recursos precisam estar a disposição das equipes no momento adequado e mecanismos que viabilizem uma comunicação eficiente precisam ser fornecidos pela coordenação. Canais de comunicação para públicos específicos e disponibilidade de informação estruturada facilitam a implementação e aliviam a carga de trabalho dos coordenadores para se dedicarem a resolver os problemas dos usuários e não os problemas de processo.

\section{Aspecto Tratamento e solução de problemas - Comunicação}

Uma estrutura de comunicação eficiente, envolvendo diretamente a coordenação do projeto facilita a implementação, já que provê suporte para as demandas administrativas dos líderes de equipe e os libera para atividades específicas de implementação.

\section{Aspecto Rede de comunicação da organização - Comunicação}

O uso de soluções de suporte a comunicação interna como a Intranet e e-mail corporativa facilitam a implementação pois fornecem canais formais de comando/orientação e repositório estruturado de informação, impulsionando uma identidade comum nas equipes e buscando atender plenamente as necessidades dos usuários internos e externos. Estes também precisam se comunicar com a organização para registrar e demandar alterações e melhorias, o suporte ao usuário final é tão importante quanto prover a integração dos envolvidos diretamente na implementação.

\section{FATORES LIGADOS AO PROJETO}

Aspecto Disposição da alta gerência para viabilizar recursos e autoridade/poder - Estratégia

A disposição da alta gerência para prover recursos e assumir a condução do projeto é fator facilitador 
da implementação, uma vez que dá legitimidade e mobiliza a estrutura corporativa naquela direção pré-estabelecida criando condições efetivas de realização do trabalho. A delegação de autoridade e competência para a média gerência se dá de forma apropriada e transparente buscando não perder de foco a totalidade do projeto e a otimização dos recursos disponíveis, integrando as implementações parciais e não duplicar esforços.

Aspecto TI vista como estratégica e vínculos com a área de tecnologia - Estratégia

A TI é entendida como estratégica na organização, o que facilita bastante a implementação das soluções visando modernização. Os recursos precisam estar disponibilizados para a função de informática poder cumprir sua vocação estratégica com eficiência, a alta gerência precisa estar integrada a coordenação do projeto e suportar suas ações quando necessário.

\section{Aspecto Eficácia de TI no longo prazo - Estratégia}

Investindo na formação e aculturamento do corpo funcional e obtendo "cases" de sucesso no curto/médio prazo, pode-se minimizar bastante a provável perda de continuidade com mudanças administrativas a cada 04 anos na prefeitura. O projeto de modernização está vinculado a programa do BNDES e garante continuidade por intervenção e financiamento dirigido independente, que acompanha e dá consultoria gerencial para implementação das mudanças.

\section{Aspecto Patrocínio adequado - Estratégia}

O patrocínio adequado e eficiente da alta direção viabiliza o projeto uma vez que garante recursos e provê continuidade. A utilização de recursos próprios da prefeitura somados ao financiamento e à adesão ao programa PMAT/BNDES legitima o processo e compartilha responsabilidades, além de incorporar "know-how" de implementações bem sucedidas e somar forças na condução das ações que realmente produzem resultados.

\section{Aspecto Definição das metas e objetivos - Planejamento}

A adesão ao programa PMAT/BNDES incorpora amplo e detalhado planejamento do projeto de modernização, a definição das metas e objetivos de forma sistemática e com visão integrada facilita a implementação. São elaborados documentos contendo diretrizes, escopo das soluções e alocação de recursos provendo publicidade e transparência ao processo.

\section{Aspecto Planejamento detalhado da implementação e cronogramas - Planejamento}

Planejamento detalhado com utilização de ferramentas gerenciais e instrumentos de controle facilitam a implementação já que disponibilizam informação adequada para melhores decisões administrativas em diversos níveis e momentos críticos. 
Aspecto Resultados de curto prazo versus Eficácia de longo prazo - Planejamento

A especificação das soluções requeridas geralmente possuem certo prazo de validade e necessitam de uma implementação de curto prazo. Esta agilidade e eficiência quando atingidas facilitam a eficácia de longo prazo, desde que não sejam negligenciados problemas como falta de integração e complementação/priorização dos subprojetos de modo a permitir ganhos de escala e adequado sequenciamento da implementação, buscando pleno cumprimento do projeto completo.

\section{FATORES LIGADOS A IMPLEMENTAÇÃO DE TI NA ADMINISTRAÇÃO PÚBLICA} Aspecto Influência dos Consultores

A contratação de serviços de consultoria externa busca complementar e formar competência internas e nunca substituí-las ou se perpetuar na condução dos trabalhos, excessão feita a contratação de serviços específicos de natureza técnica, como fabricação de software. A efetiva administração e operacão do projeto é considerada um valoroso ativo da organização, onde a influência dos consultores se restringe a problemas pontuais (sob condução da gerência interna), estes princípios de valorização do pessoal interno facilitam a implementação já que os usuários e demandantes das soluções estão diretamente engajados no processo.

\section{Aspecto Novos produtos e infra-estrutura de TI versus Consultores}

A adequada utilização de consultoria externa para efetiva formação de competência interna é fator catalisador da implementação, no médio/longo prazo se constróem equipes internas com maturidade suficiente para prestar inclusive serviços de consultoria interna em escala.

\section{Aspecto Disponibilização dos produtos versus Resistências internas}

A efetiva disponibilização dos produtos de forma apropriada colabora para diminuir resistências internas culturais e políticas e facilita as implementações futuras. A estratégia de utilizar subprojetos de grande visibilidade e resultados rápidos serve como alavanca do projeto e "cases" de sucesso devem ser utilizados em sua promoção.

\section{Aspecto Infra-estrutura de TI deficiente ou inadequada}

Uma infra-estrutura de TI deficiente ou inadequada serve de dificultador do processo já que não garante qualidade e disponibilidade para os sistemas desenvolvidos e também não suportam as atividades técnico-gerenciais diretamente ligadas a implementação das soluções. Gerenciamento, patrocínio e disponibilidade de recursos na forma e conteúdo corretos, garantem os aspectos infraestrutura tecnológica. A mobilização do conhecimento e experiência interna complementada por consultoria/treinamento busca otimizar a relação econômica-contratual com os fornecedores de produtos e serviços de infra-estrutura de TI, facilitando a implementação do projeto na organização. 
Comentários Adicionais

Principais desafios (dificultadores) a serem superados pela implementação do projeto de modernização percebidos e comentados pelos respondentes na PMSP:

- Universalização do acesso à informação - combate a exclusão digital interna e externa, prover meios de acesso (quiosques, computador popular, Telecentros, outros aparelhos públicos em escolas e bibliotecas).

- Infra-estrutura de "feed-back" eficiente - não basta haver o canal de comunicação apenas, é preciso atender com qualidade de serviço.

- Simplificação e pleno conhecimento das informações - ausência de regulamentação sobre o processo de divulgação de informações e dificuldade de encontrá-las.

- Questões de Segurança - identificação digital e segurança dos dados.

- Lógica do acesso - lógica da organização e do usuário

- Questões de Burocracia tecnológica - serviços eletrônicos meramente versões eletrônicas de serviços presenciais, processos de trabalho ultrapassados e não adequados e subaproveitamento do ganho de desempenho.

- Natureza das informações - informações sigilosas e informações públicas, qualidade da informação.

Após adesão da PMSP ao PMAT se previu primeiro a montagem e depois a realização de cursos para a gestão de TI. Enquanto isso existem ações dentro da própria administração não ligadas diretamente ao PMAT, mas que estão tentam enfocar o outro lado, que hoje é a questão da inclusão digital e que envolve toda a população.

O processo de aculturação pode ser interrompido se possivelmente uma próxima gestão não for do mesmo partido ou não possuir as mesmas diretrizes, mas se pode deixar algumas estruturas muito bem preparadas no sentido de evitar esses desvios (que muitas vezes ocorrem por mudanças inevitáveis na democracia). Só que a estrutura está preparada para conduzir estes processos e oferecer, não uma resistência, mas sim um caminho muito mais estável para ser trilhado, que nos permita ficar um pouquinho menos afeto a questão política. Hoje tem-se uma administração que está muito preocupada este ponto. Desenvolve-se um trabalho sério, onde se prepara pessoas que vão permanecer na administração independentemente de mudanças e consegue-se ter dentro desta estrutura condições para corrigir desvios muito acentuados.

Sistemas internos e serviços eletrônicos disponibilizados

O portal da prefeitura de São Paulo reúne 104 "sites", abrangendo quase todos os órgãos da prefeitura. Cada secretaria atualiza diretamente sua página e a parte tributária é das mais evoluídas, incluindo 
serviços de emissão da segunda via do IPTU, certidões negativas, consulta a débitos e a processos via portal. Entre os serviços mais importantes está o SAC, que atende mais de 80 solicitações, desde buraco na rua a troca de lâmpadas. O tempo de resposta depende de cada subprefeitura. $\mathrm{O}$ dia a dia da implementação permite dizer que o problema maior não é colocar o atendimento "on-line", e sim reorganizar o serviço público, mudar a logística e a cultura interna, produzindo serviços com qualidade e eficiência esperadas.

Buscando substancial melhoria da qualidade e descentralização do atendimento ao cidadão, o projeto inclui a disponibilização de serviços e informações via Internet e em terminais de auto-atendimento, entre eles:

- Aplicativo de preenchimento automatizado de formulários para uso eletrônico ou para impressão.

- Emissão de documentos de arrecadação para pagamento de tributos e preços públicos, com geração de código de barras, inclusive o pagamento atrasado.

- Emissão de certidão negativa.

- Consulta das certidões emitidas.

- Fornecimento de informações, produtos e serviços relativos à Dívida Ativa.

- Consulta à legislação municipal.

- Banco de dados de consulta com as questões e respostas mais freqüentes atendidas nas Secretarias.

\section{Perfil dos Respondentes}

No período de março a junho de 2003, foram entrevistados 02 coordenadores do projeto de modernização, responsáveis pelo planejamento estratégico e modelagem da parceria município de São Paulo - BNDES/PMAT. Buscando complementar o diagnóstico do processo de implementação e verificar a aderência prática ao discurso da alta gerência, foi coletada a percepção de 02 coordenadores técnicos diretamente envolvidos com a execução das mudanças nos processos internos e nos canais de relacionamento com o cliente-cidadão, ambos responsáveis pela aplicação da TI ao negócio da administração pública municipal. 


\section{2-O CASO DA PREFEITURA DE SANTO ANDRÉ}

\section{PROJETO DE MODERNIZAÇÃO DA ADMINISTRAÇÃO TRIBUTÁRIA \\ DA PREFEITURA DO MUNICÍPIO DE SANTO ANDRÉ}

Primeiramente é importante se conhecer alguns dados geográficos, sociais e econômicos do município de Santo André - ano base 2000 (Fonte - "site" oficial do governo de São Paulo) ) para contextualizar o ambiente interno e as características do cidadão-usuário dos serviços públicos.

口 Área do município $174,80 \mathrm{~km}^{2}$

口 Densidade demográfica $\left(\mathrm{hab} / \mathrm{km}^{2}\right) \quad 3.708,94$

口 População $\left(n^{\circ}\right) 649.331$

População Alfabetizada $\left(n^{0}\right) 529.664$

Alguns importantes Indicadores Econômicos (Contas Municipais):

口 Valor Adicionado Fiscal (US\$) 1.938.051.683,03

口 Repasse de ICMS para o Município (US\$) 53.070.716,88

口 Repasse de IPI para o Município (US\$) 613.659,30

口 Repasse de Compensações Financeiras para o Município (US\$) 4.309,84

Histórico e contexto do projeto de modernização

Em 1997, foi iniciado o Programa de Modernização Administrativa na cidade de Santo André, na região metropolitana da grande São Paulo, cuja meta principal foi criar um novo modelo de gestão, capaz de garantir: Prestação de serviços de qualidade e com maior produtividade e Democratização do acesso à informação, permitindo à sociedade maior controle sobre as ações da prefeitura.

Suas diretrizes básicas são:

口 abordagem voltada para o usuário;

口 descentralização e desconcentração de atribuições, com a cobrança de responsabilidade das chefias;

- horizontalização das estruturas, com ênfase em ações matriciais;

- controle e melhoria dos processos de trabalho;

- participação dos servidores na concepção, produção e avaliação do serviço;

- capacitação dos servidores para a gestão pública; e

- adoção de novas tecnologias de informação.

Preceitos básicos estabelecidos para o Projeto:

- Atratividade.

- Facilidades de navegação. 
- Acessibilidade - previsão de uso por público sem conhecimentos técnicos.

- Disponibilização de serviços.

- Informações e orientações.

- Possibilidade de interatividade - participação e cidadania.

- Transparência de gestão.

- Atendimento rápido de demandas.

- Agilidade de procedimentos e respostas.

- Inclusão digital.

O Programa tem como objetivo maior a melhoria do modelo de atendimento ao público nos órgãos governamentais. O modelo tradicional é marcado pela fragmentação e pela falta de conexão ágil e racional entre os diversos serviços e informações. Muitas vezes, para se conseguir um único documento, o usuário dos serviços públicos é obrigado a percorrer vários guichês, em andares e, não raro, em prédios diferentes. Após todos os percalços, fatalmente terá que retornar em outros dias, para ver sua solicitação atendida.

Para aprimorar e melhorar os serviços públicos, foram utilizados como princípios para a Modernização Administrativa:

1-Serviços voltados para o cidadão, e não para a burocracia pública, sem menosprezar a burocracia.

2-Descentralização e desconcentração do atendimento e de diversas decisões relacionadas com diversos serviços públicos.

3-Horizontalização das estruturas administrativas, enfatizando as ações matriciais.

4-Adoção de sistemas de controle e melhoria dos processos de trabalho.

5-Participação dos gestores (os mais diversos servidores públicos participam) na concepção, produção e avaliação dos serviços públicos.

6-Capacitação dos servidores públicos e adoção de novas tecnologias de informação.

As mudanças institucionais pretendidas envolvem Aproximação com Sociedade (aumentar a capacidade do Estado em promover e coordenar ações coletivas, aumentar a efetividade na implementação de Políticas e aumentar a eficiência dos serviços); Democratização do acesso; Transparência; Eficiência e qualidade e Responsabilização.

A grande contribuição do programa é enfrentar uma situação que é normalmente deixada completamente de lado pelos gestores públicos a partir de uma avaliação de que seus resultados não aparecem e, portanto, não geram dividendos políticos. O desenvolvimento do programa combate essa 
visão equivocada, que desconsidera o direito do cidadão ter uma prestação de serviços de qualidade.

Para romper com isso e perseguir esse novo modelo de gestão foi necessário desenvolver uma proposta abrangente, que fosse capaz de dar conta dos vários elementos necessários para enfrentar essa situação; caso contrário, apenas parte do problema estaria sendo atacado. Acredita-se que esse é um grande diferencial do programa da PMSP.

As metas mais importantes do Programa de Modernização Administrativa são quatro:

1-) Melhoria da Qualidade do Trabalho, que prevê:

- a revisão dos principais processos de trabalho a partir da visão do usuário;

- maior qualidade e eficiência nos serviços prestados;

口 introdução de indicadores de desempenho;

口 instituição do Ombudsman municipal.

2-) Valorização das Pessoas, através de:

\ desenvolvimento técnico e de habilidades dos servidores;

- readequação da cultura organizacional;

a desenvolvimento gerencial;

- estabelecimento de mecanismos de reconhecimento e de critérios de aplicação para quem trabalha bem e para quem inova.

3-) Utilização da TI na implantação de redes abertas:

- levando diferentes tipos de informação ao local do "evento" (serviços ou decisão);

口 eliminando etapas do processo de trabalho.

4-) Melhoria do Ambiente, através de:

- melhorias nas condições de trabalho: "lay-out", novos mobiliários e equipamentos, ergonomia etc.

- criação de espaços de convivência e aprendizagem dos servidores em seus locais de trabalho;

Os objetivos específicos estabelecidos para o Projeto: Desenvolvimento de novas ferramentas que permitam a participação cidadã e o exercício de direitos da comunidade; Redução do abismo entre camadas mais pobres e mais ricas da população; Democratização das informações; Possibilidades de controle social da administração pública; Estímulo ao exercício da interferência da comunidade nos destinos da cidade e; Foro de discussão sobre soluções mais apropriadas para os problemas da comunidade. 
Em 1998 foi iniciada a operacionalização do "site". No ano de 2001, se verificou que a Internet da Prefeitura estava com uma imagem obsoleta e foi criada uma iniciativa de mudança de seu design e viu-se a necessidade de uma nova organização dos dados de modo a facilitar a procura daqueles que a visitavam.

Para definição do novo layout inicialmente foi realizado um trabalho de pesquisa em diversos "sites", para adquirir algumas idéias das tecnologias que estavam se usando. A partir do momento de definição do novo layout e disponibilização da ferramenta utilizada para gerenciamento do "site", realizou-se primeiramente um trabalho de migração dos dados da internet antiga para a nova que foi colocada no ar em 30/04/2002. Este trabalho de migração contou com o esforço da equipe envolvida e demorou mais ou menos 3 semanas para ser concluído de um total de quase 700 páginas estáticas.

Após a migração dos dados que já existiam, digo dados estáticos, houve também a migração dos serviços que já eram disponibilizados no "site" antigo, na fase inicial os serviços não sofreram alterações lógicas e sim somente alterações estéticas.

A ferramenta de organização do "site" além de possibilitar uma fácil alimentação de dados para formação de página estática, possui outros recursos como criação e gerenciamento de enquetes, "chats", fóruns, cadastros; e também dados estatísticos como por exemplo, medições de páginas mais visitadas, total de páginas estáticas no "site", etc.

A ferramenta é executada no próprio "browser", não necessitando ser instalada em cada estação, e tem uma interface de fácil utilização muito semelhante aos produtos Microsoft como o Word, facilitando o uso das diversas áreas envolvidas, pois no projeto de "Governo Eletrônico" em Santo André tem-se como ideal que cada área seja responsável pela atualização dos seus dados, fazendo com que o resultado final que é a informação liberada para o munícipe seja publicada mais rapidamente não precisando passar na mão de terceiros para ser criada e sim apenas aprovada.

Para que as áreas tenham a segurança que apenas elas vão alterar os seus dados e a possibilidade que a ferramenta nos dá em relação a criação de grupos de acesso onde se define as áreas da página que aquele grupo terá acesso e, em cada grupo se disponibilizam os usuários que devem acessar as permissões daquele grupo.

A transformação na área de informática marcou uma mudança na cultura interna da prefeitura. Hoje a área conta com 1.500 micros em rede e com 42 servidores NT e um Unix. A partir daí, muitos procedimentos internos foram substituídos por meios eletrônicos, isso agilizou em muito o trabalho 
da equipe. Para tornar disponíveis os serviços na Internet, informatizar a comunicação interna e modernizar o parque tecnológico, a prefeitura investiu para garantir a segurança das informações que passaram a trafegar na rede. Antes de utilizar as ferramentas de segurança, os ataques de "hackers", que invadiam o "site", eram constantes.

Diretrizes estabelecidas para a operação do "site" público Externo:

- Acessível.

- Facilidade de localização.

- Navegação amigável.

- Distribuição de conteúdos por associação.

- Facilidade de acessar conteúdos desejados com o mínimo de procura.

- Facilidades de situar o usuário no "site".

- Orientações claras - sem uso de linguagem técnica e exclusiva.

- Combate ao pânico tecnológico.

Diretrizes estabelecidas para a operação do "site" público Interno:

- Desenvolvimento e operação do módulo básico da intranet.

- Ferramenta interna - agilidade e rapidez de procedimentos internos e combate à burocracia.

- Facilidades de comunicação interna.

- Ferramenta para a participação dos servidores e colaboradores da PMSA.

- Atendimento rápido de demandas internas.

- Simplificação de solicitações de serviços.

\section{Implementação do Projeto}

O primeiro passo foi escolher dentre as principais áreas prestadoras de serviços um processo - chave cuja melhoria causasse impacto imediato no usuário. O processo escolhido foi acelerar os procedimentos e as decisões do Departamento de Controle Urbano, responsável pelo licenciamento e fiscalização de construções, através de otimização de rotinas, eliminação de etapas, utilizando sistemas informatizados dentre os quais o Sistema de Informações Geográficas.

No diagnóstico, foi levantado que para acelerar decisões e procedimentos o departamento dependia de informações de outros departamentos da prefeitura para a análise das solicitações, retardando os pareceres e as decisões, com alto impacto nos prazos de concessão dos alvarás. Para solucionar a questão, foram inseridas no Sistema de Informações Geográficas informações sobre planos viários, a lei de uso e ocupação do solo, as quadras fiscais com o desenho da quadra e as divisões dos lotes e dados cadastrais, entre outros. Com a inserção destes dados, pelos usuários responsáveis pelas informações e as mesmas disponibilizadas em rede, houve uma mudança cultural importante, pois os 
processos deixaram de "andar" pelas diversas áreas da prefeitura, uma vez que as informações foram disponibilizadas na Intranet. Desta forma, o acesso à informação é compartilhado e as decisões são mais rápidas.

Tanto as informações georeferenciadas como os serviços informatizados foram disponibilizados à população com a implantação da Rede Fácil, que se constitui de três formas de atendimento, que se integram e se complementam:

- Atendimento Pessoal: praça de atendimento e postos SIM - Serviço Integrado Municipal; atende centenas de usuários por dia, processos redesenhados e utilização de rede com múltiplas tecnologias suporta o atendimento.

- Atendimento pela Internet: informações sobre cerca de 500 serviços, permite a solicitação de todos os serviços do "call-center" e vários da Praça, média de 30 solicitações por dia e 4 reclamações.

- Atendimento pelo Fone Fácil: "call-center" que atende centenas de usuários por dia, onde um sistema de gerenciamento de ordens de serviço dá suporte ao atendimento.

A diretoria de Informática, direcionou o foco na agilização do atendimento das demandas da população com a criação da Praça de Atendimento, um local que reúne todos os serviços oferecidos pela prefeitura, com amplo acesso a recursos de informática, reduzindo o tempo de atendimento das solicitações.

$\mathrm{Na}$ Praça de Atendimento, implantada em junho/99, cento e oitenta serviços foram reformulados, diminuindo -se os caminhos que os documentos percorriam nos principais setores da prefeitura e extinguindo- se carimbos e assinaturas desnecessárias, sempre com o foco voltado para a qualidade do atendimento ao munícipe, objetivando rapidez e descomplicação. Foram necessários investimentos para a renovação do parque de informática da prefeitura e para o desenvolvimento de sistemas apropriados para a nova forma de trabalho propiciando serviços e informações "on-line" . Com tudo isso, atualmente cerca de $70 \%$ dos usuários tem sua situação resolvida na hora.

A Praça de Atendimento realiza cerca de 800 atendimentos por dia, das 08:00 às 18:00 hs, atende tipicamente assuntos de Controle Urbano e Tributos; mas também processos gerais, possui plantão técnico diário de arquitetos e engenheiros de Controle Urbano e serviço de auto-atendimento para juntada de documentos e consulta de andamento de processos. O quadro de pessoal alocado é de 30 atendentes (mesas, balcão e suporte), 2 gerentes técnicos e 01 gerente administrativo, o tempo de espera médio é de 20 minutos e o tempo de atendimento médio é de 12 minutos.

Os demais serviços são aqueles que ainda necessitam de alguma tramitação interna como, por 
exemplo, aprovação de projetos para construção. Os 2 Postos SIM, implantados em 1997, permitiram a população local acesso aos mesmos serviços disponibilizados na Praça de Atendimento. Por estes postos passam diariamente 60 pessoas/dia.

Para viabilizar a Praça foram necessárias mudanças nos processos de trabalho, envolvendo revisão de cerca de 180 serviços para melhoria da agilidade e resolução, além da centralização do atendimento. Os atendentes são funcionários de carreira em função gratificada com treinamento em atendimento e especialização. Por meio de TI se busca disponibilizar a informação no local do evento e a prestação de serviços imediatos

O "site" da Prefeitura, em funcionamento desde setembro de 1998, propicia ao cidadão o acesso a cópias de quadras fiscais, a mapas da cidade, solicitar segunda via de tributos, certidões, consultar legislações municipais, editais etc. $\mathrm{O}$ "site" recebe a visita de 4 mil pessoas/mês. O passo seguinte seria levar os serviços da administração para a Internet. "Na nossa visão, os novos recursos tecnológicos eram um instrumento importante que não podiam ser ignorados e precisavam ser colocados à disposição dos cidadãos", diz a diretora. Hoje, dos cerca de 180 serviços disponíveis para os moradores na Praça de Atendimento e Postos SIM (Serviço Integrado Municipal), próximo de 50\% já estão disponíveis no "site" da cidade.

O Fone Fácil, em funcionamento desde setembro/99, tornou- se um dos maiores instrumentos para facilitar a vida dos cidadãos andreenses, potencializando um dos canais de comunicação mais importantes entre a prefeitura e a população. Consiste de uma central com 10 pontos de atendimento durante doze horas por dia, atendendo em média 400 pessoas/dia. Acompanha e dá retorno aos munícipes sobre reclamações, serviços solicitados, bem como verifica o grau de satisfação com o serviço realizado ou as providencias tomadas, permitindo identificar pontos que precisam de melhorias.

O Fone Fácil possui enfoque Receptivo (informações e solicitação de serviços, reclamações e denúncias, sugestões e elogios) e enfoque Ativo (campanhas como a do Orçamento Participativo, avaliação dos serviços - "pós-venda" e pesquisas/sondagens). Provê tipicamente serviços urbanos e de vigilância sanitária com cerca de 80 serviços disponíveis para solicitação e média de 16.500 atendimentos por mês. Suas premissas de funcionamento incluem disponibilizar fluxo de informações entre as áreas e o atendimento telefônico, preocupação com a qualidade dos registros no trâmite das solicitações e necessidade de atenção aos compromissos assumidos.

Para recuperar a capacidade gerencial da administração pública, foi necessário implantar um sistema que possibilitasse o controle público sobre os serviços, do ponto de vista da qualidade e do acesso. 
Para concretizar este objetivo, em abril de 1999 a prefeitura começou o levantamento dos serviços considerados de maior impacto para a vida dos munícipes, estabelecendo prazos e condições de execução para cada um deles e transformando -os em compromissos assumidos publicamente, ou seja, o que a prefeitura é efetivamente capaz de realizar.

Assim, aproximadamente 500 serviços considerados mais relevantes tiveram seus parâmetros indicadores identificados. Além dos compromissos, as informações levantadas contemplam a descrição do serviço, o local de acesso, os horários de atendimento, as taxas (quando há) e os documentos necessários. Todas essas informações, além de disponíveis na Rede Fácil, foram trabalhadas e publicadas no formato de um guia de serviços denominado "Guia Fácil", que foi distribuído gratuitamente em todos os domicílios da cidade, ver Quadro 13.

\begin{tabular}{|l|c|c|}
\hline \multicolumn{1}{|c|}{ Serviço } & Antes do projeto & Depois do projeto \\
\hline Alvará de construção & 60 dias & 5 dias \\
Alvará de uso do solo Certidão & 60 dias & 5 dias \\
negativa de tributos & 10 dias & imediato \\
Certidão de valor venal & 5 dias & imediato \\
$2^{\text {a }}$ Via de tributos & 9 dias & imediato \\
Regularidade fiscal mobiliária & 10 dias & imediato \\
Parcelamento de débitos & 30 dias & imediato \\
Encerramento de comércio e & 60 dias & imediato \\
indústria & & \\
\hline
\end{tabular}

QUADRO 13 - Resultados já alcançados com a implantação da Rede Fácil

Secretaria de Finanças de Santo André

Área de Atuação: Planejamento e Execução dos trabalhos relativos a arrecadação da receita e execução da despesa municipal e coordenar o controle interno das finanças municipais. Principais funções:

- Coordenação e supervisão das atividades relativas a arrecadação da receita, através dos tributos mobiliários, imobiliários, contribuições de melhoria e transferências estaduais e federais;

- Fiscalização dos tributos municipais, tais como o IPTU, ISS, ITBI e outros;

- Promover a medidas visando a cobrança da dívida ativa e débitos fiscais;

- Supervisionar a execução, fluxo de caixa, empenho e pagamento da despesa;

- Efetuar os registros contábeis e prestar contas junto aos órgãos competentes;

- Avaliar e fiscalizar os resultados da execução contábil, financeira e orçamentária da administração direta e indireta, através da atuação da coordenadoria de controle interno. 
Revisão no processo de Fiscalização de cobrança de tributos municipais

O processo de cobrança de tributos envolve não só o atendimento ao cliente, mas também a modernização da máquina administrativa que permita melhorar a fiscalização da arrecadação e diminuir as perdas. Um dos temas mais abordados pela imprensa em termos tributários é a intensidade cada vez maior de corrupção nos processos de arrecadação tributária. A corrupção no sistema de fiscalização tributária leva a desgaste e perda de credibilidade do setor público por parte da população, além de alto custo para apuração das denúncias.

O processo de fiscalização tributária municipal se preocupa, além da questão da corrupção, com a inadimplência e a sonegação. Neste sentido, afirma-se que muitas vezes o contribuinte municipal não é propriamente um sonegador que se utiliza de artifícios ilegais para lesar o fisco municipal, mas um contribuinte esquecido ou não acostumado a contribuir com a gestão municipal, principalmente em decorrência de falta de legitimidade do poder público e da certeza de impunidade ou de inúmeros benefícios concedidos ao contribuinte inadimplente. Neste último caso, observa-se que benefícios e parcelamentos estabelecidos posteriormente ao lançamento do tributo, estimulam o adiamento da contribuição.

Santo André é um município da região metropolitana de São Paulo, com $100 \%$ da população vivendo na zona urbana. Seu crescimento esteve vinculado ao desenvolvimento industrial da região, de modo que a arrecadação tributária esteve muito suscetível às variações do nível de atividade econômica do país.

Com a diminuição do ritmo do crescimento econômico do país com forte impacto sobre a indústria de bens duráveis, como veículos automotores e outras indústrias metal mecânicas, acrescida de uma perda de legitimidade do poder público e a necessidade de redefinir relações entre o poder público constituído e a sociedade civil, a administração pública, em Santo André, viu-se com a necessidade de criar instrumentos para reverter, ou pelo menos, modificar, esta situação.

Se por um lado, criou instrumentos de participação popular como forma de legitimar a gestão e racionalizou o uso dos recursos públicos do lado das despesas; pelo lado das Receitas, dentre outros mecanismos, a administração de Santo André instituiu instrumentos para aprimorar a arrecadação tributária própria. Estes instrumentos estão inseridos num contexto mais amplo de modernização administrativa e são condicionados por dois eixos de ação: capacitação pessoal e informatização do departamento tributário.

A Secretaria de Finanças, ao participar do Programa de Modernização Administrativa, está obtendo grandes mudanças em sua atuação. Com a melhoria da qualidade do trabalho, está oferecendo um 
atendimento mais digno e justo. A Secretaria de Finanças passou por um processo de reforma de suas instalações e equipamentos. O setor de atendimento ao público foi inteiramente reformulado, os guichês estão munidos de equipamentos informatizados e os servidores foram capacitados de modo que a sua atenção esteja voltada para o público. Este, por sua vez, tem enfrentado pouquíssimas filas.

A valorização do funcionalismo se dá a partir do desenvolvimento técnico e de habilidades dos servidores e da readequação da cultura organizacional. Além da reforma do espaço, criou-se na Secretaria de Finanças um ambiente de respeito e confiança, a partir do estímulo à participação dos servidores e do estabelecimento de mecanismos de reconhecimento do trabalho. Com reuniões periódicas, está sendo possível conscientizar os fiscais de seu papel e importância. Eles se sentem mais incentivados a cooperar e a atuar de forma honesta. Além disso, há uma preocupação deles em desempenharem sua função eficientemente, pois, como a Secretaria de Finanças tem ido atrás dos estabelecimentos comerciais e de serviços e cobrado a tributação devida a partir de estimativas, fica mais fácil identificar os fiscais que não têm colaborado com a administração pública. Por último, cabe ressaltar que estão sendo organizados processos de seleção de novos fiscais. Estes passam por um treinamento, tendo em vista sua futura atuação.

Quanto à utilização de TI, além da aquisição de novos computadores, está sendo implementada na Secretaria de Finanças um programa de rede. Todos os dados introduzidos nos computadores poderão ser processados por um núcleo central, que tem como função, a fiscalização da cobrança tributária, tornando-a mais ágil e eficiente.

A melhoria do ambiente de trabalho foi a primeira etapa concluída. Houve uma grande alteração no desempenho e motivação dos servidores, uma vez que o local de trabalho tornou-se agradável, com luz e equipamentos próprios para escritório.

Deve-se observar que o Consórcio do $\mathrm{ABC}$ exerce importante papel no que diz respeito a diminuição da Guerra Fiscal, visto que são definidas, por meio dessa "instituição" as atividades prioritárias de cada município e a alíquota de ISS conveniente. Desse modo, as empresas não buscam nos municípios vizinhos ilhas fiscais para exercício de suas atividades. Em geral, o Consórcio Intermunicipal do $\mathrm{ABC}$ estabelece parâmetros e alíquotas convenientes para os diversos prefeitos da região, de modo que em vez de vizinhos predatórios, tornam-se parceiros importantes.

Objetivos da Revisão do Processo de Fiscalização em Santo André:

- aumentar a arrecadação utilizando com maior plenitude o potencial arrecadatório do município;

- melhorar a equidade horizontal e vertical da política tributária local;

- fomentar a contribuição voluntária da contribuição; e 
- melhorar a eficiência na arrecadação de tributos.

A revisão do processo de fiscalização tributária tem início com uma revisão e maior detalhamento do cadastro municipal de contribuintes, tanto do IPTU quanto do ISS. No caso do IPTU, o processo de fiscalização concentra-se muitas vezes na Secretaria de Obras que acompanha a evolução, ou pelo menos, as modificações ocorridas nas propriedades (reformas e ampliações), como forma de manutenção e atualização do cadastro; e na negociação dos créditos tributários de modo que não favoreça o inadimplente, mas pelo contrário, estimule a contribuição sem atrasos.

No que diz respeito ao ISS, a Prefeitura de Santo André reviu o processo de fiscalização tributária e estabeleceu duas frentes de atuação: uma interna, de atualização do cadastro com detalhamento das informações, com maior precisão sobre a localização da empresa, bem como um histórico de seu faturamento e o número de funcionários. $\mathrm{Na}$ frente interna ainda, há um posterior processamento dessas informações num banco de dados informatizado. Trata-se da montagem de uma retaguarda para permitir uma atuação mais eficaz da frente externa.

O processo externo de fiscalização consiste em, a partir de uma estimativa do crédito tributário, apurar in loco o pagamento efetivo dos carnês lançados. Para a efetivação desse processo, a prefeitura realizou uma Estimativa de Arrecadação para aproximadamente 100 atividades econômicas diferentes. Trata-se de atividades em que um grande número de contribuintes espalhados.

Para o cálculo das estimativas para os prestadores de serviços partiu-se da hipótese de que pequenos e microempresários das mais diversas áreas, desde consultórios médicos até oficinas mecânicas, passando por cabeleireiros, bares e locadoras, dificilmente emitem nota fiscal, pelo próprio tipo de serviço e pela não exigência do cliente. A prefeitura então foi a esses pontos comerciais verificar seus custos. Daí estabeleceu um patamar mínimo de manutenção do negócio, que hoje serve de base para o pagamento do ISS. A título de exemplo, imagine que, para manter uma locadora, seu proprietário gaste R\$ 2 mil por mês. Para permanecer no negócio sem lucro, ele deverá ter receita mínima igual a este valor, que é, para a prefeitura, base para a arrecadação do ISS. Esse processo foi realizado para aproximadamente 100 atividades econômicas.

Uma vez calculadas as estimativas, os carnês são lançados. Além da estimativa, é realizada uma apuração dos dados in loco, por amostragem, sendo que os fiscais são subdivididos em diversas áreas de fiscalização no município. Essa verificação também é realizada para os contribuintes que se sintam prejudicados pela estimativa. O não pagamento do carnê também é apurado in loco. Nesse momento de apuração, o contribuinte é estimulado a quitar o crédito tributário e só em última instância é inscrito na dívida ativa. 
Paralelo a isso a prefeitura vem se empenhando em um processo de monitoramento dos maiores contribuintes. Deve-se ressaltar que cerca de 180 grandes contribuintes representam aproximadamente $52 \%$ da arrecadação do ISS.

\section{Resultados obtidos na Secretaria de Finanças de Santo André}

Além de uma arrecadação mais eficiente e eficaz, o processo de fiscalização tributária em Santo André tem apresentado alguns resultados de difícil mensuração.

Em primeiro lugar, esta prática tem rompido com a cultura de sonegação, tão presente na realidade brasileira. Ao invés de deixar sob responsabilidade do governo federal, ou mesmo do estadual, as prefeituras devem criar mecanismos que facilitem a arrecadação municipal. Dessa maneira, um segundo resultado visível tem sido combater a prática de inércia tributária, tão característica das prefeituras brasileiras. Deve-se ressaltar que estas mudanças ocorridas na gestão pública de Santo André foram possíveis pela legitimidade do processo conquistado através da publicidade das contas públicas e pela participação efetiva da comunidade no processo orçamentário, definindo a alocação dos recursos públicos.

\section{Percepção dos respondentes}

Foram citados o aumento/melhoria da comunicação interna e busca de maior visibilidade externa como Motivações iniciais do projeto. A rede municipal foi implantada após processo de "downsizing" na área de informática. Internamente também foi implementada a modernização apoiada pela TI, mas como uma extensão de um projeto cujo foco mais visível eram os serviços eletrônicos disponibilizados aos cidadãos.

Como Metas e Objetivos iniciais foram citados a transparência de governo, aumento de serviços eletrônicos para os funcionários e para os cidadãos e maior facilidade/agilidade na comunicação interna e externa.

O projeto se originou na alta gerência como plataforma de governo e sua justificativa se baseou na modernização administrativa e consequentes relações de custo/benefício para o município e seus cidadãos. O financiamento do projeto se deu inicialmente com recursos próprios do município e mais recentemente com a adesão ao programa PMAT do BNDES.

\section{FATORES LIGADOS A PESSOAS}

Aspecto Recrutamento, seleção e treinamento de pessoal - Recursos Humanos

Foi relatado como facilitador da implementação a realocação de pessoal interno, buscando otimizar a 
utilização de competências existentes e a formação de especialistas. Foi apresentado como dificultador do processo o mecanismo de licitação pública utilizado para contratação de consultores externos, pela relativa demora e burocracia para obter os recursos humanos de forma apropriada.

\section{Aspecto Competência dos líderes e autoridade - Recursos Humanos}

Foi percebido como facilitador da implementação a utilização de engenheiros, administradores de rede/sistema e analistas de sistemas com elevado nível de experiência e conhecimento nas funçõeschave de liderança e autoridade, de modo a qualificar a gerência dos trabalhos. A atuação destes profissionais internos à organização conta com total respaldo do Núcleo de Modernização Administrativa. Foi apresentado como dificultador do processo a necessidade de buscar a competência e a liderança necessárias totalmente fora da organização, situação que não existiu neste projeto.

\section{Aspecto Aptidões do pessoal e uso de consultoria - Recursos Humanos}

Foi relatado como facilitador da implementação a não utilização de consultoria externa para administração do projeto, buscou-se valorizar o pessoal interno qualificado, já que os envolvidos conheciam melhor que ninguém os problemas e a cultura da organização. A utilização de consultoria externa complementar aos quadros internos também foi apontada como facilitador do processo, principalmente na operacionalização das soluções.

\section{Aspecto Uso das melhores práticas e lições aprendidas - Recursos Humanos}

Percebeu-se como facilitador da implementação a cultura de utilizar as práticas de mercado mais adequadas e a busca por constante atualização tecnológica do pessoal envolvido, suportadas por mecanismos de treinamento/reciclagem proporcionados pelo corpo diretivo do projeto. Situação oposta seria considerada dificultador do processo.

\section{Aspecto Fatores externos sobre a equipe - Ambiente}

Observa-se como facilitador da implementação a consciência da missão, da importância e dos objetivos do projeto por parte de todos os envolvidos em sua realização. Situação oposta seria considerada dificultador do processo.

Aspecto Percepção das necessidades dos clientes e disposição para mudanças - Ambiente

Trata-se de fator facilitador da implementação a existência da equipe de Coordenação da Modernização que revisa os processos e procura otimizar o trabalho conjunto dos diversas áreas internas - sua clientela, utilizando-se para isso da centralização de experiências e da especialização de seus membros. Foi percebido como facilitador do processo a disposição do pessoal envolvido - corpo diretivo, líderes e servidores técnicos-administrativos - para realizar a mudança. Foi considerado 
dificultador do processo o descrédito dos funcionários na implementação das mudanças e melhoria das condições de trabalho.

Aspecto Realidade político-administrativa versus Prazo de maturação do projeto - Ambiente Foi considerado facilitador da implementação a continuidade político-administrativa, a possibilidade de um segundo mandato favoreceu o amadurecimento do projeto. Questões como integração/otimização de sistemas, revisão de processo e mudança cultural, dependem essencialmente de tempo e de uma equipe coesa, que se consegue com o tempo. Uma situação de quebra de continuidade ou mudança de rumo da alta gerência seria considerado dificultador do processo.

\section{FATORES LIGADOS AO PRODUTO}

Aspecto Percepção da importância do produto e da necessidade de implementação - Produto final

Como se trata de plataforma de governo, sempre existiu na alta gerência a percepção da importância do produto e da necessidade de implementação. Procurou-se disseminar para o público interno e externo o porquê do programa de modernização, seus objetivos e benefícios para os cidadãos e para a prefeitura, de modo a motivar e integrar as pessoas ao projeto, facilitando sua implementação.

\section{Aspecto Definição do escopo do produto - Produto final}

Dados os recursos e o limite do mandato existe um planejamento de governo com cronograma definido e produtos intermediários com custo e impacto associados, uma detalhada definição do escopo dos produtos internos/externo aliada ao planejamento adequado são imprescindíveis como facilitadores do processo.

\section{Aspecto Resistência dos usuários - Produto final}

Comentou-se que não existem mudanças sem problemas, faz parte da natureza humana, mas em Santo André procurou-se dar vários e pequenos passos, foi dito que o município já tem um governo informatizado a bem mais de duas décadas. Para facilitar a implementação do projeto é preciso arrefecer a resistência dos usuários internos e externos, oferecendo treinamento e informação adequados a cada público e cada produto.

Aspecto Comunicação, consulta e consideração de todas as partes afetadas pelo projeto Relacionamento com o Cliente

A Coordenadoria de Modernização faz esta avaliação, não somente interna, mas também dos cidadãos. Dentre as diversas formas de comunicação utilizadas conta-se também com uma ouvidoria da cidade. A não-existência destes mecanismo de aferição e contato com os "stakeholders" do projeto seria um dificultador enorme da implementação. 
Aspecto Venda do projeto para o usuário final - Relacionamento com o Cliente

Existe a prática de realizar um planejamento para fornececimento de informação antes da implantação, visando o envolvimento dos usuários no projeto, seguido de treinamento, acompanhamento e suporte. Além disso, muitas vezes os próprios usuários ajudaram a definir as customizações realizadas. Estas práticas são fundamentais e facilitam sobremaneira a implementação.

\section{Aspecto Tipo de relacionamento com o cliente - Relacionamento com o Cliente}

Busca-se uma interação progressiva em que o cliente participa do projeto, a tecnologia atual facilita alterações e customizações provendo um ambiente dinâmico. A interação progressiva é fator facilitador do processo, deve-se aplicar o tipo de relacionamento adequado a cada tipo de cliente, externo e interno. Existe um dificultador da implementação relacionado a aceitação do auto-serviço via Internet pelos usuários.

\section{Aspecto Disponibilidade de tecnologia e especialização - Tecnologia}

As dificuldades de implementação de questões de "Governo Eletrônico" se referem a revisão de processo, principalmente ligadas ao fator humano. A disponibilidade de tecnologia no momento adequado e a especialização dos técnicos e gerentes são fatores facilitador da implementação bem sucedida.

\section{Aspecto Trato da mudança de tecnologia - Tecnologia}

Há pelo menos 30 anos a informática sofre modificações constantes, o conhecimento e a experiência da equipe diretamente envolvida é fator facilitador da implementação, de modo a utilizar a tecnologia com melhor custo/benefício para resolver cada problema específico, sem contudo perder a visão mais ampla e de longo prazo. Um facilitador do processo está ligado a oportunidade de implementação direta de aplicações usando tecnologia Internet integradas ao legado.

\section{Aspecto Seleção de tecnologia e integração ao legado - Tecnologia}

Procura-se manter um ambiente homogêneo, uma equipe de administração da rede/sistema enxuta e diminuir nossos custos de suporte/manutenção técnica. A incapacidade de decidir pela tecnologia mais adequada para cada parte do projeto e a não integração dos novos sistemas ao legado existente são fatores dificultadores do processo.

\section{FATORES LIGADOS AO PROCESSO}

Aspecto Modificações das regras de negócio - Eficiência

Toda etapa de sucesso leva a novas necessidades e melhorias, decorrentes do bom uso da solução. A realização destas modificações é suportada por mecanismos que informam os clientes dos benefícios e do porquê das mudanças, na área pública normalmente as modificações são mais lentas do que na 
iniciativa privada, dando mais tempo para adequar os sistemas às alterações de regras. Para uma administração mal preparada ou carente de recursos adequados, constantes modificações das regras de negócio pode se tornar um importante dificultador do processo.

Aspecto Normas versus Desempenho - Eficiência

Esta se caminhando para um ambiente fortemente regulado. Quando as normas interna da organização são inflexíveis ou equivocadas podem comprometer o desempenho dos produtos e das equipes, tornando-se um dificultador da implementação.

\section{Aspecto Mensuração da eficiêncialeficácia - Eficiência}

A Coordenadoria de Modernização realiza medidas de eficiência e eficácia dos subprojetos e das equipes, de modo a subsidar a alta gerência de elementos para melhores decisões e facilitar o processo. Uma dificuldade do processo se refere ao acompanhamento eficaz da execução orçamentária do projeto.

\section{Aspecto Obtenção e disponibilização das informações gerenciais - Controle}

Boa parte da implementação é terceirizada. O controle é feito através de cronograma e supervisão de etapas feita pela equipe interna. $\mathrm{O}$ boa e adequada obtenção e disponibilização das informações gerenciais é fator facilitador do processo, situação oposta foi considerada dificultador da implementação.

Aspecto Tratamento das mudanças nas regras de negócio - Controle

Cada conjunto de mudanças é tratado como subprojeto individual, o que garante melhor gerenciamento e controle, existe também uma priorização das mudanças que agregam mais valor para o cliente facilitando o processo como um todo.

\section{Aspecto Adequação dos prazos - Controle}

Os prazos acordados sempre devem ser cumpridos, visto que são trabalhos normalmente contratados junto a terceiros. Boas prática de controle de cronograma e prazos facilita sobremaneira a implementação do projeto.

Aspecto Obtenção e disponibilização dos dados e canais de comunicação - Comunicação

O Núcleo de Modernização Administrativa, subordinado ao Gabinete do Prefeito, entre outras funções, se propõe a disponibilizar e viabilizar canais de comunicação entre os clientes internos/externos e as equipes técnicas, buscando facilitar a implementação do projeto de modernização. A ausência de informação e a dificuldade de comunicação interna são enormes barreiras ao bom desempenho do processo. 
Aspecto Tratamento e solução de problemas - Comunicação

Sendo a área de informática extremamente mutável, aliado ao aumento constante de usuários e de serviços, esta se torna uma habilidade inata dos sobreviventes desta área o adequado tratamento dos problemas diversos, em especial os ligados a comunicação das partes envolvidas na solução, de modo a viabilizar e facilitar a implementação bem sucedida.

Aspecto Rede de comunicação da organização - Comunicação

Com a melhoria da comunicação interna e treinamento, devido aos avanços de solução de TI implementada para este fim, a rede de comunicação vem melhorando de forma consistente facilitando sobremaneira o processo de implementação.

\section{FATORES LIGADOS AO PROJETO}

\section{Aspecto Disposição da alta gerência para viabilizar recursos e autoridade/poder - Estratégia}

Percebe-se como imprescindível para um implementação adequada e bem sucedida, a disponibilidade de recursos e a correta delegação de competências técnico-gerencias são facilitadores do projeto de modernização bem sucedido.

\section{Aspecto TI vista como estratégica e vínculos com a área de tecnologia - Estratégia}

A área de TI é vista como estratégica para a organização e tratada como participante ativa do seu planejamento estratégico. A não aceitação da TI como estratégica na solução dos problemas é fator limitante e dificultador do processo. Um facilitador da implementação se refere a cobrança da sociedade por melhores serviços e presença do governo na Internet.

\section{Aspecto Eficácia de TI no longo prazo - Estratégia}

Planejamento estratégico com objetivos concretos de longo, médio e curto prazo, aliado a um processo de aculturamento com revisão de processos e fundamentado numa equipe de carreira engajada. Estas iniciativas buscam a eficácia contínua da TI para a organização e seus clientes, visão esta que facilita bastante a implementação do projeto de modernização.

\section{Aspecto Patrocínio adequado - Estratégia}

A existência de patrocínio adequado e engajado no projeto é fator facilitador do processo. Caso não haja apoio de patrocinador da alta gerência da organização, fica comprometida a realização do projeto, uma vez que não haverá respaldo financeiro e legitimidade para implementação.

\section{Aspecto Definição das metas e objetivos - Planejamento}

Relatada a existência de planejamento estratégico detalhado, cobrindo todo o período de governo e 
agindo como facilitador da implementação por subsidiar e orientar decisões gerenciais.

Aspecto Planejamento detalhado da implementação e cronogramas - Planejamento

O planejamento detalhado da implementação e o cumprimento de cronogramas, efetivamente tem efeito facilitador no processo, uma vez que subsidia os gerentes de informações críticas para um bom trabalho.

Aspecto Resultados de curto prazo versus Eficácia de longo prazo - Planejamento

O projeto tem objetivos de longo, médio, e curto prazos por definição. Com direito a revisões constantes. Nesta área não é possível manter um projeto por longo tempo sem resultados. Além disso prioridades e tecnologia/custos mudam rapidamente. Assim, é provável que um projeto com resultados a longo prazo não tenham eficácia, pois a realidade do momento da especificação não existe mais. Boa parte dos projetos fracassados estão relacionados a isto. Projetos que não fornecem resultados no curto prazo são considerados difíceis de implementar.

\section{FATORES LIGADOS A IMPLEMENTAÇÃO DE TI NA ADMINISTRAÇÃO PÚBLICA} Aspecto Influência dos Consultores

A influência dos consultores é limitada a funções técnicas e o controle gerencial está com o pessoal da organização, que melhor conhece os problemas a serem enfrentados e a cultura da casa. Uma organização que não assume sua função de administrar seus processos e atender bem sua clientela é fator dificultador de projetos bem sucedidos, a alta dependência externa se torna uma barreira dentro da organização para evolução da implementação.

\section{Aspecto Novos produtos e infra-estrutura de TI versus Consultores}

Questões de infra-estrutura de TI e os novos produtos a serem disponibilizados devem obedecer uma definição da alta gerência do projeto. Consultoria externa e treinamento são bem vindos como subsídios para melhores decisões gerenciais do corpo diretivo do órgão público. A correta delimitação e divisão adequada dos papéis técnicos, gerenciais e políticos dentro da organização são fatores facilitadores da boa implementação do projeto.

Aspecto Disponibilização dos produtos versus Resistências internas

A disponibilização dos produtos suportados pela TI devem ser executadas obedecendo questões de ordem econômica (melhor visibilidade e custo-benefício), mas não podem perder de vista resistências internas por aversão ou má condução da reengenharia de processos. Amenizar a resistência dos funcionários por meio de informação e treinamento, inserindo-os na implementação é facilitador da implementação dos produtos e novos processo de trabalho. 
Aspecto Infra-estrutura de TI deficiente ou inadequada

Uma infra-estrutura de TI não compatível com as necessidades e o escopo do projeto é um dificultador extremo da sua implementação. A boa prática de simular e especificar a demanda de cada produto/serviço por hardware e software específicos facilita e viabiliza o projeto como um todo.

\section{Comentários Adicionais}

Para melhor implementação de "Governo Eletrônico", a automação de atividades e a racionalização dos procedimentos implicam em transformações radicais dos processos de trabalho, e não apenas agilização destes processos. O desenvolvimento de governo na Internet acompanha as transformações da sociedade, garantindo que todos possam ser capazes de interagir com ele preservando o exercício pleno da cidadania.

Passado o momento de concepção do programa, o primeiro obstáculo enfrentado foi o de garantir a adesão a ele. Isso exigiu um esforço grande de esclarecimento da concepção do programa para a equipe de governo, para as chefias intermediárias e para o conjunto dos servidores. Isso era essencial pois sem essa adesão não seria possível desenvolver o programa com sucesso, visto que isso só ocorreria a partir do compromisso com as metas estabelecidas dentro de suas áreas.

O primeiro momento de entrada em cada uma das áreas foi diferenciado, alguns com muita expectativa e outros esperando para ver se o programa era para valer. Foi essencial, então, a figura do multiplicador, um servidor indicado por cada Secretário para acompanhar as ações de modernização na sua área, que, em conjunto com a equipe do Núcleo de Modernização Administrativa foi contornando as dificuldades.

Essa função foi especialmente importante para o trabalho de revisão de processos de trabalho, mas progressivamente o multiplicador foi assumindo esse papel nas outras três frentes de trabalho.

Um segundo obstáculo foi o da montagem e integração dos grupos de trabalho matriciais, responsáveis pela condução das ações das diversas frentes de trabalho. A forma de organização adotada inicialmente não propiciava a integração o que afetou o andamento do trabalho em seu início. Com o tempo ajustes foram feitos, que minoraram o problema.

Porém, a principal dificuldade para o desenvolvimento do programa é inerente a ele, ou seja, a dificuldade que quem conduz a máquina pública, sejam os servidores de carreira seja os da equipe de governo, tem de se deter no seu dia a dia e perceber que é possível melhorar.

As resistências decorrentes da cultura organizacional vigente de que o serviço sempre foi realizado de 
uma maneira e para quê mudar?, aliada à amplitude do programa e sua característica de apresentar resultados mais globais no médio e longo prazos compõem o quadro de maior dificuldade que se tem enfrentado.

As atividades relacionadas à valorização das pessoas (formação e programa de cultura organizacional), a vinculação permanente de qualquer ação com a logomarca do programa (sinais claros da mudança) e as ações concretas nas áreas têm minimizado, mas não resolvido essa situação. Já é possível perceber nos setores mais atingidos pelas ações do programa uma clara mudança de postura.

Sistemas internos e serviços eletrônicos já implementados

Neste novo "site" existe a facilidade de disponibilizar, assim que alguma área solicitar serviços como enquetes, "chats", cadastros e até fóruns, mantendo estatísticas destes serviços. A seguir os serviços eletrônicos de maior destaque:

- Mapas separados por várias áreas como educação, saúde, áreas verdes, etc.

- Consulta acompanhamento de processos.

- Declaração da DAME.

- Quadra Fiscal.

- Solicitação de Segunda via de tributos imobiliários como IPTU e contribuição de melhorias e, mobiliários como ISS homologado, ISS Ofício, Taxa de Licença e Taxa de Publicidade.

- Solicitação de serviços de manutenção.

- Cesta Básica.

- Serviços Ofertados.

- Lei de Responsabilidade Fiscal.

- Serviços urbanos e de vigilância sanitária.

- Solicitações de certidões.

- GIS - mapa da cidade com localização de equipamentos públicos.

- Legislação municipal.

- Licitações: cadastramento de fornecedores, divulgação e entrega de editais.

- Anuário de dados do município.

- Mapa do Site.

Está se trabalhando numa facilidade de disponibilizar formulários de tributos, controle urbano e até formulários padrão para preenchimento "on-line" e impressão, facilitando a vida do munícipe que antes precisava vir até a Prefeitura se informar e pegar os formulários, depois preenche-los a máquina e trazer de volta para a Prefeitura, agora com esta facilidade o município acessa o "site" seleciona o 
formulário que deseja, verifica as informações de preenchimento, impressão, documentos necessário e número de vias e vem 1 vez só na Prefeitura com o formulário já preenchido e com os documentos já providenciados. Alguns serviços que estão disponíveis no "site" vão passar por uma nova adequação com as novas ferramentas e até a disponibilização de novas funções.

Para o Ambiente Intranet foi desenvolvido um módulo básico de intranet com disponibilização de serviços como: enquetes, "chats", fóruns, cadastros, classificados, notícias, eventos, normas internas, legislação, serviço de e-mail, link com o CATI permitindo abrir e consultar os chamados referentes a problemas de informática, link com telefonia para notificação de problemas com telefone, e desenvolvimento de alguns sistemas, de RH como Consulta de ocorrências, férias, biênios e banco de horas; DMP como Consulta de patrimônio, de solicitação de pedido de compra, pesquisa de patrimônio por CR; DEF...

\section{Pontos de destaque do Projeto}

Numa escala própria de complexidade , o "Governo Eletrônico" da cidade de Santo André, na Grande São Paulo, está no terceiro nível dos quatro possíveis. O projeto iniciado em 1998 começou como "site" informativo. Dois anos depois, foi a vez da modalidade "serviços" ser somada ao portal, que recebeu sistema integrado de segurança. Com a rede mais estabilizada, bloqueio de "sites", detector de invasão e de intrusos internos e externos trabalhando junto com o "firewall", pode-se desenvolver o "Governo Eletrônico" de fato.

Atualmente, os moradores da cidade já podem solicitar poda de árvores, segunda via do IPTU e outros serviços, com a certeza de receber dentro de 24 ou 48 horas um e-mail com a resposta de quando será atendido. E, agora, com todas as secretarias interligadas em rede, o projeto já chega ao terceiro patamar, caracterizado por transações eletrônicas mais complexas. No meio do próximo ano os cidadãos poderão pagar IPTU e ISS, por exemplo, assim como poderão obter guias de vigilância sanitária e fazer alterações nos seus cadastros. Até 2004, o objetivo é ter $90 \%$ dos serviços do município no Portal.

Tantas transformações no modo de trabalhar gerou resistência por parte de alguns funcionários. É exatamente por isso que a coordenadoria de modernização administrativa cuida para que os usuários se envolvam bastante com as mudanças e enxerguem que elas estão trazendo melhorias".

O terceiro estágio do "Governo Eletrônico" em Santo André também envolve um sistema de leilão que está em processo de licitação - para agilizar as compras e baixar os gastos do órgão. Esse será um outro mecanismo para administrar melhor o dinheiro dos cidadãos. 
O sistema por trás do "site" e das centrais físicas de atendimento é o mesmo, assim como a ferramenta utilizada para o acompanhamento dessas solicitações - desenvolvida por terceiros na época em que foi lançada e profundamente modificada pela equipe da prefeitura, no ano passado. Em Santo André ainda se busca atingir um outro patamar: a integração das três esferas do governo.

Os esforços atuais do Projeto passam pelo Aperfeiçoamento e/ou criação de Sistemas de Indicadores do Atendimento; Formação e desenvolvimento gerencial com ênfase em Gestão por Resultados e Aproximação da Modernização com os canais coletivos de participação cidadã.

\section{Perfil dos Respondentes}

No período de fevereiro a abril de 2003, foram entrevistados 02 coordenadores do projeto de modernização, responsáveis pelo planejamento estratégico e implementação das diretrizes políticas definidas pela alta administração. Buscando complementar o diagnóstico do processo de implementação e verificar a aderência prática ao discurso da alta gerência, foi coletada a percepção de 02 coordenadores técnicos diretamente envolvidos com a execução das mudanças nos processos internos e nos canais de relacionamento com o cliente-cidadão, ambos responsáveis pela aplicação da TI ao negócio da administração pública municipal. 


\section{3-Análise entre os Casos à luz do referencial teórico}

De modo a melhor entender e comparar as similaridades e diferenças entre os Casos estudados, apresentamos no Quadro 14 um resumo dos fatores condicionantes destacados pelos respondentes:

\begin{tabular}{|c|c|c|c|c|}
\hline & Caso São Paulo & & Caso Santo André & \\
\hline $\begin{array}{l}\text { Viés de } \\
\text { Percepção dos } \\
\text { respondentes }\end{array}$ & $\begin{array}{l}\text { Facilitador da } \\
\text { implementação }\end{array}$ & $\begin{array}{l}\text { Dificultador da } \\
\text { implementação }\end{array}$ & $\begin{array}{l}\text { Facilitador da } \\
\text { implementação }\end{array}$ & $\begin{array}{l}\text { Dificultador da } \\
\text { implementação }\end{array}$ \\
\hline \multicolumn{5}{|l|}{$\begin{array}{l}\text { Fator } \\
\text { condicionante }\end{array}$} \\
\hline $\begin{array}{l}\text { PESSOAL - } \\
\text { Recursos } \\
\text { Humanos }\end{array}$ & $\begin{array}{l}\text { Inserção dos } \\
\text { usuários na } \\
\text { definição das } \\
\text { soluções de TI, } \\
\text { Treinamento para } \\
\text { complementar } \\
\text { competência } \\
\text { internas e nivelar } \\
\text { conhecimentos, } \\
\text { Equipes } \\
\text { multidisciplinares }\end{array}$ & $\begin{array}{l}\text { Inexistência de } \\
\text { coordenação } \\
\text { central para } \\
\text { atividade de } \\
\text { gerência de RH e } \\
\text { treinamento, Não } \\
\text { comprometimento } \\
\text { do corpo } \\
\text { funcional com o } \\
\text { projeto }\end{array}$ & $\begin{array}{l}\text { Realocação de } \\
\text { pessoal, Consultoria } \\
\text { pontual e de } \\
\text { formação, } \\
\text { Valorização do } \\
\text { gerenciamento } \\
\text { interno e Cultura de } \\
\text { atualização/treiname } \\
\text { nto }\end{array}$ & $\begin{array}{l}\text { Processo moroso } \\
\text { para licitação para } \\
\text { serviços de } \\
\text { treinamento/consult } \\
\text { oria, Ausência de } \\
\text { coompetências } \\
\text { internas específicas } \\
\text { e Desmotivação } \\
\text { salarial }\end{array}$ \\
\hline $\begin{array}{l}\text { PESSOAL - } \\
\text { Ambiente }\end{array}$ & $\begin{array}{l}\text { Transparência e } \\
\text { informação } \\
\text { estruturada para } \\
\text { todos os } \\
\text { envolvidos, } \\
\text { Iniciativas de } \\
\text { resultados no } \\
\text { curto prazo, } \\
\text { Inovação e desafio }\end{array}$ & $\begin{array}{l}\text { Não priorizar as } \\
\text { pessoas e sim a } \\
\text { tecnologia, Clima } \\
\text { não favorável para } \\
\text { mudanças }\end{array}$ & $\begin{array}{l}\text { Conscientização } \\
\text { maciça e } \\
\text { Continuidade } \\
\text { político- } \\
\text { administrativa }\end{array}$ & $\begin{array}{l}\text { Indisposição inicial } \\
\text { para mudanças e } \\
\text { Longo prazo de } \\
\text { maturação de } \\
\text { subprojetos, } \\
\text { Descrédito dos } \\
\text { funcionários }\end{array}$ \\
\hline $\begin{array}{l}\text { PRODUTO - } \\
\text { Produto final }\end{array}$ & $\begin{array}{l}\text { Percepção da } \\
\text { importância do } \\
\text { produto e das } \\
\text { necessidades dos } \\
\text { clientes, } \\
\text { Comunicação e } \\
\text { treinamento } \\
\text { eficientes para } \\
\text { vender o produto, } \\
\text { Imagem de } \\
\text { modernidade }\end{array}$ & $\begin{array}{l}\text { Definição do } \\
\text { escopo das } \\
\text { soluções sem } \\
\text { participação ativa } \\
\text { dos usuários e } \\
\text { funcionários }\end{array}$ & $\begin{array}{l}\text { Projeto como } \\
\text { plataforma de } \\
\text { governo, Prática de } \\
\text { implementação } \\
\text { gradual mas } \\
\text { constante, com } \\
\text { entrega de produtos } \\
\text { intermediários }\end{array}$ & $\begin{array}{l}\text { Aversão natural dos } \\
\text { usuários a mudanças } \\
\text { e novas tecnologias, } \\
\text { Dificuldade de } \\
\text { prever o impacto do } \\
\text { produto final }\end{array}$ \\
\hline $\begin{array}{l}\text { PRODUTO - } \\
\text { Relacionamen } \\
\text { to com o } \\
\text { cliente }\end{array}$ & $\begin{array}{l}\text { Recrutamento de } \\
\text { talentos internos e } \\
\text { de pessoal nos } \\
\text { clientes, } \\
\text { Relacionamento } \\
\text { gradual e } \\
\text { estabelecimento } \\
\text { da confiança }\end{array}$ & $\begin{array}{l}\text { Não inserção dos } \\
\text { fornecedores e } \\
\text { usuários finais na } \\
\text { construção das } \\
\text { soluções de TI, } \\
\text { Implementação } \\
\text { imposta de cima } \\
\text { para baixo }\end{array}$ & $\begin{array}{l}\text { Ouvidoria e canais } \\
\text { de relacionamento } \\
\text { interno, Usuário } \\
\text { envolvido } \\
\text { diretamente na } \\
\text { definição das } \\
\text { soluções de TI }\end{array}$ & $\begin{array}{l}\text { Não existência de } \\
\text { suporte a } \\
\text { relacionamentos } \\
\text { especifícos para } \\
\text { públicos distintos na } \\
\text { organização, Não } \\
\text { aceitação do auto- } \\
\text { serviço pelos } \\
\text { usuários }\end{array}$ \\
\hline $\begin{array}{l}\text { PRODUTO - } \\
\text { Tecnologia }\end{array}$ & $\begin{array}{l}\text { Recursos/consulto } \\
\text { ria pela adesão ao }\end{array}$ & $\begin{array}{l}\text { Trato da TI sem } \\
\text { visão de longo }\end{array}$ & $\begin{array}{l}\text { Conhecimento e } \\
\text { experiência das }\end{array}$ & $\begin{array}{l}\text { Incapacidade de } \\
\text { decidir pela }\end{array}$ \\
\hline
\end{tabular}




\begin{tabular}{|c|c|c|c|c|}
\hline & $\begin{array}{l}\text { programa } \\
\text { PMAT/BNDES, } \\
\text { Capacitação para } \\
\text { escolher } \\
\text { fornecedores e } \\
\text { aproveitar } \\
\text { recursos } \\
\text { tecnológicos } \\
\text { existentes }\end{array}$ & $\begin{array}{l}\text { prazo, Erros e } \\
\text { equívocos na } \\
\text { escolha das } \\
\text { tecnologias }\end{array}$ & $\begin{array}{l}\text { equipes, Manter } \\
\text { ambiente } \\
\text { homogêneo e } \\
\text { equipes } \\
\text { enxutas/coesas, } \\
\text { Oportunidade de } \\
\text { aplicação direta da } \\
\text { tecnologia Internet }\end{array}$ & $\begin{array}{l}\text { tecnologia, Não } \\
\text { integração ao } \\
\text { legado, } \\
\text { Mutabilidade da } \\
\text { tecnologia }\end{array}$ \\
\hline $\begin{array}{l}\text { PROCESSO - } \\
\text { Eficiência }\end{array}$ & $\begin{array}{l}\text { Definição } \\
\text { equivocada das } \\
\text { regras de negócio, } \\
\text { Uso do modelo } \\
\text { CMM como } \\
\text { parâmetro para } \\
\text { desenvolvimento } \\
\text { de software, } \\
\text { Mensuração } \\
\text { adequada do } \\
\text { andamento dos } \\
\text { trabalhos } \\
\end{array}$ & $\begin{array}{l}\text { Não previsão do } \\
\text { nível de } \\
\text { flexibilidade } \\
\text { necessário das } \\
\text { soluções junto aos } \\
\text { usuários p/ } \\
\text { suportar } \\
\text { modificações } \\
\text { temporais, } \\
\text { Excesso de } \\
\text { normatização }\end{array}$ & $\begin{array}{l}\text { Relativa } \\
\text { estabilidade das } \\
\text { regras de negócio na } \\
\text { área pública, } \\
\text { Ambiente } \\
\text { fortemente regulado, } \\
\text { Uso de indicadores } \\
\text { gerenciais }\end{array}$ & $\begin{array}{l}\text { Não inclusão do } \\
\text { usuário final no } \\
\text { escopo da solução, } \\
\text { Normatização } \\
\text { interna inflexível ou } \\
\text { equivocada }\end{array}$ \\
\hline $\begin{array}{l}\text { PROCESSO - } \\
\text { Controle }\end{array}$ & $\begin{array}{l}\text { Boas práticas de } \\
\text { captação e } \\
\text { fornecimento de } \\
\text { informações } \\
\text { gerenciais, } \\
\text { Priorizar } \\
\text { implementações } \\
\text { de melhor relação } \\
\text { custo/benefício, } \\
\text { Uso de } \\
\text { contratação por } \\
\text { nível de serviço } \\
\text { SLA }\end{array}$ & $\begin{array}{l}\text { Não utilização de } \\
\text { modelo de } \\
\text { qualidade para } \\
\text { engenharia de } \\
\text { software, Prazos e } \\
\text { demais } \\
\text { indicadores são } \\
\text { negligenciados } \\
\text { pela coordenação } \\
\text { ou pelas equipes }\end{array}$ & $\begin{array}{l}\text { Cada conjunto de } \\
\text { mudanças é tratado } \\
\text { como subprojeto } \\
\text { independente, } \\
\text { Priorização de } \\
\text { trabalhos e } \\
\text { implementação } \\
\text { técnica realizada por } \\
\text { terceiros }\end{array}$ & $\begin{array}{l}\text { Informação } \\
\text { insuficiente para } \\
\text { tomada de decisão, } \\
\text { Dificuldade de } \\
\text { acompanhamento do } \\
\text { orçamento/desembol } \\
\text { so }\end{array}$ \\
\hline $\begin{array}{l}\text { PROCESSO - } \\
\text { Comunicação }\end{array}$ & $\begin{array}{l}\text { Existência de } \\
\text { canais de } \\
\text { comunicação para } \\
\text { públicos } \\
\text { específicos, } \\
\text { Disponibilidade } \\
\text { de informação } \\
\text { estruturada, } \\
\text { Fomento da } \\
\text { identidade comum } \\
\text { das equipes }\end{array}$ & $\begin{array}{l}\text { Ineficiência da } \\
\text { comunicação } \\
\text { interna ou externa, } \\
\text { Incapacidade de } \\
\text { integrar e suportar } \\
\text { implementações } \\
\text { parciais e legado }\end{array}$ & $\begin{array}{l}\text { Utilização de canais } \\
\text { como Intranet, site } \\
\text { da prefeitura e e- } \\
\text { mail, Treinamento } \\
\text { em comunicação, } \\
\text { Qualidade dos } \\
\text { serviços de rede }\end{array}$ & $\begin{array}{l}\text { Comunicação } \\
\text { interna insuficiente } \\
\text { ou de via única, } \\
\text { Informação } \\
\text { desestruturada e de } \\
\text { difícil acesso }\end{array}$ \\
\hline $\begin{array}{l}\text { PROJETO - } \\
\text { Estratégia }\end{array}$ & $\begin{array}{l}\text { Alta gerência } \\
\text { engajada no } \\
\text { projeto, Utilização } \\
\text { de "cases" de } \\
\text { sucesso internos, } \\
\text { Foco na } \\
\text { aculturação do } \\
\text { corpo funcional, } \\
\text { Adesão ao }\end{array}$ & $\begin{array}{l}\text { Não transparência } \\
\text { e publicidade das } \\
\text { ações estratégicas } \\
\text { e relacionamento } \\
\text { com fornecedores, } \\
\text { Perda de foco e } \\
\text { continuidade } \\
\text { administrativa a } \\
\text { cada mandato de }\end{array}$ & $\begin{array}{l}\text { Apoio da alta } \\
\text { gerência para } \\
\text { viabilizar recursos, } \\
\text { Aculturamento e } \\
\text { revisão de processos } \\
\text { a partir da cúpula, } \\
\text { Patrocínio adequado } \\
\text { (legitimidade e } \\
\text { respaldo), Cobrança }\end{array}$ & $\begin{array}{l}\text { Toda etapa de } \\
\text { sucesso implica em } \\
\text { novas necessidade e } \\
\text { melhorias, Não } \\
\text { entendimento da } \\
\text { área de TI como } \\
\text { estratégica para a } \\
\text { organização }\end{array}$ \\
\hline
\end{tabular}




\begin{tabular}{|c|c|c|c|c|}
\hline & $\begin{array}{l}\text { programa } \\
\text { PMAT/BNDES } \\
\text { compartilhando } \\
\text { responsabilidades } \\
\text { e "Know-how" }\end{array}$ & 04 anos & da sociedade & \\
\hline $\begin{array}{l}\text { PROJETO - } \\
\text { Planejamento }\end{array}$ & $\begin{array}{l}\text { Definição de } \\
\text { metas e objetivos } \\
\text { de forma } \\
\text { sistêmica e com } \\
\text { visão integrada, } \\
\text { Uso de } \\
\text { ferramentas e } \\
\text { práticas gerencias } \\
\text { do programa } \\
\text { PMAT/BNDES }\end{array}$ & $\begin{array}{l}\text { Não } \\
\text { aproveitamento } \\
\text { dos ganhos de } \\
\text { escala na } \\
\text { implementação } \\
\text { com duplicação de } \\
\text { esforços, Não } \\
\text { priorização e } \\
\text { sequenciamento } \\
\text { equivocado das } \\
\text { ações }\end{array}$ & $\begin{array}{l}\text { Uso de } \\
\text { planejamento } \\
\text { estratégico } \\
\text { detalhado, } \\
\text { Informação } \\
\text { adequada para } \\
\text { tomada de decisão }\end{array}$ & $\begin{array}{l}\text { Projetos que visam } \\
\text { resultados somente } \\
\text { no longo prazo não } \\
\text { tem eficácia, } \\
\text { Mutabilidade das } \\
\text { necessidades no } \\
\text { médio prazo e prazo } \\
\text { de validade das } \\
\text { soluções }\end{array}$ \\
\hline $\begin{array}{l}\text { TI aplicada na } \\
\text { Administração } \\
\text { Pública - } \\
\text { Consultoria }\end{array}$ & $\begin{array}{l}\text { Deve-se } \\
\text { privilegiar } \\
\text { formação de } \\
\text { competência } \\
\text { interna e } \\
\text { valorização do } \\
\text { corpo funcional } \\
\end{array}$ & $\begin{array}{l}\text { Tornar-se } \\
\text { dependente de } \\
\text { consultoria } \\
\text { externa ou } \\
\text { fornecedores }\end{array}$ & $\begin{array}{l}\text { Consultoria externa } \\
\text { limitada a funções } \\
\text { técnicas e formação } \\
\text { interna }\end{array}$ & $\begin{array}{l}\text { A organização não } \\
\text { assume o papel de } \\
\text { gerir suas } \\
\text { mudanças, Alto grau } \\
\text { de dependência } \\
\text { externa }\end{array}$ \\
\hline $\begin{array}{l}\text { TI aplicada na } \\
\text { Administração } \\
\text { Pública - } \\
\text { Novos } \\
\text { produtos }\end{array}$ & \begin{tabular}{|l} 
Reconhecer a \\
maturidade das \\
equipes internos \\
como gestores de \\
TI validadas pelos \\
novos produtos
\end{tabular} & $\begin{array}{l}\text { Não explorar as } \\
\text { oportunidades de } \\
\text { vencer a } \\
\text { resistência interna } \\
\text { com os novos } \\
\text { produtos } \\
\text { disponibilizados }\end{array}$ & $\begin{array}{l}\text { A alta gerência } \\
\text { estabelece diretrizes } \\
\text { e participa de } \\
\text { definições } \\
\text { estratégicas, } \\
\text { Prioridade para } \\
\text { subprojetos com } \\
\text { visibilidade e boa } \\
\text { relação custo- } \\
\text { benefício }\end{array}$ & $\begin{array}{l}\text { Delimitação e } \\
\text { divisão de papéis } \\
\text { inadequada ou } \\
\text { insuficiente }\end{array}$ \\
\hline $\begin{array}{l}\text { TI aplicada na } \\
\text { Administração } \\
\text { Pública - } \\
\text { Infra-estrutura }\end{array}$ & $\begin{array}{l}\text { Disponibilização } \\
\text { eficiente e gestão } \\
\text { adequada da infra- } \\
\text { estrutura de TI } \\
\text { para uso } \\
\text { interno/externo }\end{array}$ & $\begin{array}{l}\text { Não garantia da } \\
\text { disponibilidade e } \\
\text { do nível de } \\
\text { serviço }\end{array}$ & $\begin{array}{l}\text { Práticas de } \\
\text { simulação de } \\
\text { demanda de infra- } \\
\text { estrutura de TI }\end{array}$ & $\begin{array}{l}\text { Carência de } \\
\text { informação e } \\
\text { treinamento para } \\
\text { contratar/comprar, } \\
\text { Infra-estrutura de TI } \\
\text { insuficiente ou } \\
\text { inadequada }\end{array}$ \\
\hline $\begin{array}{l}\text { Outros fatores } \\
\text { dispersos }\end{array}$ & $\begin{array}{l}\text { Estruturar a } \\
\text { organização para a } \\
\text { mudança } \\
\text { continuar } \\
\text { independentement } \\
\text { e da } \\
\text { descontinuidade } \\
\text { político- } \\
\text { administrativa }\end{array}$ & $\begin{array}{l}\text { Exclusão digital e } \\
\text { não- } \\
\text { universalização do } \\
\text { acesso a } \\
\text { tecnologia }\end{array}$ & $\begin{array}{l}\text { Automação de } \\
\text { atividades e } \\
\text { racionalização de } \\
\text { procedimentos }\end{array}$ & $\begin{array}{l}\text { Incapacidade de } \\
\text { acompanhar as } \\
\text { transformações da } \\
\text { sociedade e entender } \\
\text { suas necessidades }\end{array}$ \\
\hline
\end{tabular}

QUADRO 14 - Resumo dos fatores condicionantes destacados pelos respondentes

A coleta de dados nas prefeituras de São Paulo e Santo André revelou alguns fatores comuns 
percebidos no processo de modernização administrativa municipal suportado pela TI em relação aos aspectos de risco apresentados por Backus (2001), quando se examina o risco de implementar soluções de governança na Internet para países em desenvimento:

- Estabilidade política (eleições, democracia ou regime ditatorial) - este aspecto não foi diretamente comentado, porém se ressaltou o caráter facilitador/dificultador relacionado a continuidade da implementação do projeto de modernização quando da mudança de governo a cada 04 anos. Outros pontos relacionados são a cobrança da sociedade e a visão do Projeto como plataforma de governo, aspectos entendidos como facilitadores da implementação em Santo André.

- Nível de confiança no governo (percepção dos níveis de serviço) - este aspecto foi percebido como condicionante da implementação nas prefeituras pesquisadas, foram citados como fatores facilitadores a iniciativa de entregar resultados no curto prazo, o estabelecimento da confiança através de um relacionamento gradual e constante, com entrega de produtos intermediários e a existência da canais de relacionamento como Ouvidoria. Fatores dificultadores relacionados são o não comprometimento e o descrédito do corpo funcional, aliados a aversão natural das pessoas às mudanças.

- Importância da identidade do governo (fragmentação ou integração) - a existência de patrocínio adequado, alta gerência engajada no projeto, participação do corpo funcional e planejamento sistêmico com visão integrada foram percebidos como facilitadores do processo de implementação nas prefeituras, caso contrário se tornam importantes obstáculos a serem superados. Na prefeitura de São Paulo ressaltou-se a utilização de "cases" de sucesso internos e o foco na aculturação do corpo funcional como facilitador do processo.

口 Estrutura econômica (instrução, agricultura, indústria ou serviço) - a cultura de atualização/treinamento foi citada na prefeitura de Santo André como facilitador da implementação.

- Estrutura de governo (centralizada ou descentralizada) - relacionados a este aspecto foram percebidos como dificultadores a implementação imposta de cima para baixo sem participação e envolvimento do corpo funcional e a comunicação ineficiente aliada a falta de informação/transparência. A superação destes obstáculos foi considerada imprescindível para viabilizar o projeto de modernização nas prefeituras.

- Diferentes níveis de maturidade (a parte a mais fraca da corrente determina a velocidade) foram citados como facilitadores relacionados a este item - fomento da identidade comum nas equipes, formação de competência interna buscando nivelar conhecimentos, divulgação das experiências de sucesso, manter ambiente homogêneo e equipes enxutas/coesas, valorização/engajamento do corpo funcional no projeto. Como dificultadores percebidos nas prefeituras, tem-se a dependência de consultoria externa/fornecedores e a delimitação/divisão de papéis inadequada ou insuficiente. 
- Demanda eleitoral - na prefeitura de Santo André o projeto de modernização é entendido como plataforma de governo e atende uma demanda da sociedade (fator facilitador). $\mathrm{Na}$ prefeitura de São Paulo também se percebe esta preocupação com a melhoria dos serviços e incremento da eficiência/eficácia dos processos viabilizando o projeto.

Com relação ao modelo SWOT definido no trabalho de Backus (2001), existem algumas correspondências e similaridades com aspectos facilitadores e dificultadores percebidos nas prefeituras pesquisadas, a seguir apresentamos uma análise parcial envolvendo forças e fraquezas.

Forças (fatores facilitadores) que possuem forte correspondência com a percepção coletada na implementação de projetos de modernização suportados pela TI nas prefeituras pesquisadas:

- combinação com reformas e democratização;

- possibilidade de um salto de modernidade com a Internet;

- pessoas dispostas a aprender;

- financiamento internacional facilitado pela busca da governança apoiada pela Internet (nos casos o financiamento foi obtido com adesão ao programa PMAT/BNDES complementado com recursos próprios);

- busca de transparência nos negócios e transações.

Forças (fatores facilitadores) não relacionadas com a percepção coletada nas prefeituras:

- tudo é novidade: problemas jurídico-legais;

- $\quad$ estabelecimento de padrões de TI;

- desenvolvimento das pessoas possibilitando exportar produtos.

Fraquezas (fatores dificultadores) que possuem forte correspondência com a percepção coletada na implementação de projetos de modernização suportados pela TI nas prefeituras pesquisadas:

- processo de tomada de decisão ineficiente;

- orçamento;

- curto prazo entre as eleições (continuidade);

- integração e reforma;

- baixa nível educacional: necessidade de treinamento;

- aceitação pública dos modelos de auto-serviço;

- controle do orçamento;

- poucos especialistas de TI no governo;

- heterogenidade dos dados. 
Fraquezas (fatores dificultadores) não relacionadas com a percepção coletada nas prefeituras:

- ausência de legislação específica de Internet;

- nenhum dono do problema dentro do governo;

- baixa especialização em tecnologia Internet;

- hierarquia acentuada;

- pouco conhecimento em TI;

- diferenças de idiomas;

- escassez de conhecimento (competição com o setor privado);

- investidores;

- altos custos da Internet.

Já no trabalho de Netto (2000) é relatada a percepção de alguns elementos inibidores e propulsores relacionados ao uso/adoção de soluções informatizadas na modernização da Secretaria da Fazenda do Estado de São Paulo. A coleta de dados nas prefeituras de São Paulo e Santo André revelou fatores com algum grau de correspondência com os elementos colhidos na Sefaz-SP e outros fatores específicos da implementação de projetos de modernização administrativa Municipal suportado pela TI.

A seguir os Fatores Dificultadores percebidos com algum grau de correspondência com o trabalho de Netto (2000) na Sefaz-SP:

- Tempo exíguo entre a aprovação e a implantação do programa de modernização - baixa correspondência já que nas prefeituras pesquisadas existem aspectos facilitadores relacionados a prática de implementação gradual e constante, com entrega de produtos intermediários (Santo André) e iniciativas de resultado de maior impacto no curto prazo (São Paulo).

- Mudança no comando e descrédito dos funcionários - alta correspondência, foram citados fatores dificultadores relacionados como perda de foco e continuidade administrativa a cada 04 anos (São Paulo), descrédito dos funcionários e aversão a mudanças (Santo André).

- Corporativismo e desconfiança das lideranças - alta correspondência, foram citados fatores dificultadores relacionados como clima não favorável para mudanças e não comprometimento do corpo funcional com o projeto (São Paulo), aversão natural dos usuários a mudanças e novas tecnologias (Santo André).

- Infra-estrutura necessária - alta correspondência, foram citados fatores dificultadores relacionados como não garantia da disponibilidade e do nível de serviço (São Paulo) e infraestrutura insuficiente/inadequada (Santo André).

- Montagem de equipe de manutenção e transferência de tecnologia - alta correspondência, 
foram citados fatores dificultadores relacionados como tornar-se dependente de consultoria externa e fornecedores (São Paulo e Santo André) e delimitação/divisão de papéis inadequada ou insuficiente (Santo André). A utilização de equipes multidisciplinares, coesas e enxutas, e o aproveitamento das competências internas foram citados como facilitadores do processo.

- Divulgação deficiente - alta correspondência, foram citados fatores dificultadores relacionados como ineficiência da comunicação interna/externa (São Paulo) e ausência de informação estruturada e transparência (Santo André).

- Desconhecimento de experiência similar no Brasil e exterior - baixa correspondência já que nas prefeituras pesquisadas existem aspectos facilitadores relacionados como adesão ao programa PMAT/BNDES compartilhando responsabilidades e "know-how" (São Paulo e Santo André) e utilização de consultoria externa, além de existência de diversos casos de implementação em organizações públicas no Brasil e no exterior para adoção de melhores práticas.

- Capacitação e treinamento do corpo funcional em curto espaço de tempo - alta correspondência, foram citados fatores dificultadores relacionados como não priorizar as pessoas e sim a tecnologia (São Paulo) e processo moroso para licitação de serviços de treinamento/consultoria (Santo André).

- Restrições ditadas pela legislação - alta correspondência, foram citados fatores dificultadores relacionados como excesso de normatização (São Paulo) e normatização interna inflexível ou equivocada (Santo André).

Com relação aos Fatores Facilitadores percebidos nas Prefeituras pesquisadas existe alto grau de correspondência com os aspectos propulsores coletados por Netto (2000) na Sefaz-SP:

- Aprovação por órgãos internacionais e pelo público externo - aspecto facilitador relacionado a fatores como recursos/consultoria pela adesão ao programa federal PMAT/BNDES (São Paulo e Santo André) e cobrança da sociedade, plataforma de governo (Santo André).

- Caráter inovador e pioneiro - aspecto facilitador relacionado a fatores como imagem de modernidade, oportunidade de inovação e desafio (São Paulo ) e aculturamento e revisão de processos (Santo André).

a Criatividade e combate ao imobilismo - aspecto facilitador relacionado a fatores como uso de equipes multidisciplinares, recrutamento e "cases" de sucesso internos (São Paulo) e uso de conhecimento/experiência das equipes, conscientização maciça dos envolvido e priorização de trabalhos (Santo André).

口 Produtos disponibilizados vão suplantando a resistência política - aspecto facilitador relacionado a fatores como entrega de produtos intermediários de forma gradual e constante (Santo André) e iniciativas de resultados no curto prazo (São Paulo).

口 Conhecimento do negócio pela equipe de projeto - aspecto facilitador relacionado a fatores 
como inserção dos usuários na definição/implementação das soluções de TI e uso/formação de consultoria interna (São Paulo e Santo André)

- Contratação de consultores externos especialistas em TI - aspecto facilitador relacionado a fatores como consultoria externa limitada a funções técnicas e formação interna (São Paulo e Santo André). Um importante dificultador relacionado seria o nível de dependência de consultoria externa/fornecedores.

- Sinergia entre equipes - aspecto facilitador relacionado a fatores como fomento da identidade comum entre as equipes, uso de consultoria e "cases" de sucesso internos (São Paulo), comunicação eficiente com uso da Intranet e valorização do pessoal interno (Santo André).

- Cobrança da sociedade - aspecto facilitador relacionado a fatores como cobrança da sociedade e projeto entendido como plataforma de governo (Santo André), melhoria da eficiência/eficácia interna para prover melhores serviços públicos (São Paulo e Santo André).

- Apoio da alta administração - aspecto facilitador relacionado a fatores como alta gerência engajada para viabilizar recursos e patrocínio adequado provendo legitimidade e respaldo político/gerencial (São Paulo e Santo André).

Robic e Sbragia (1995) apresentam 21 fatores condicionantes considerados relevantes enquanto elementos que influenciam o desempenho de projetos de informatização.Os três critérios mais importantes de avaliação do desempenho de projetos de informatização parecem ser a satisfação do cliente, a qualidade técnica e a validade organizacional (adequação do projeto às necessidade do usuário). Estes três aspectos também foram percebidos como facilitadores de elevada importância nas Prefeituras pesquisadas com referência a implementação de projetos de modernização administrativa municipal viabilizada pela TI.

Foi coletado em campo que a participação e o envolvimento dos usuários internos/externos para definição e implementação das soluções de TI conforme suas necessidades são fatores imprescindíveis para sucesso de projetos de modernização nas Prefeituras, isto aliado ao aspecto qualidade técnica das equipes envolvidas, que foi obtida através do uso de consultoria externa para funções técnicas e treinamento para formação e valorização do corpo funcional.

Albertin (2001) realizou um estudo multicasos no segundo semestre de 1999 com 99 empresas distribuídas por setores: Banco (12\%), Comércio (6\%), Indústria (43\%) e Serviços (39\%). Os casos estudados avaliaram os fatores críticos de sucesso de projetos de TI, segundo a importância de cada um deles, utilizando os 14 fatores apontados por Pinto e Slevin (1988).

Constatou-se que a visão da empresas está focada principalmente em três fatores mais citados pelos respondentes: apoio da alta gerência, qualidade das tarefas técnicas e acompanhamento e controle. O 
fator Apoio da alta gerência foi tido como o mais importante, permitindo concluir que as empresas dos vários setores consideram que, para o sucesso dos projetos de TI, precisam do envolvimento e comprometimento da alta gerência durante todo o ciclo de vida dos projetos. A indicação de Qualidade das tarefas técnicas e Acompanhamento e controle, permite concluir que a importância dos projetos de TI reside, principalmente, na fase de execução dos projetos.

As constatações da pesquisa de Albertin possuem correspondência com fatores facilitadores/dificultadores colhidos nas prefeituras de São Paulo e Santo André. Aspectos como patrocínio adequado e apoio da alta gerência viabilizam recursos, provém legitimidade e autoridade para uma implementação bem sucedida. Com referência ao processo de implementação propriamente dito o modelo de Pressman para projetos de TI se mostrou adequado para subsidiar o levantamento dos principais elementos condicionantes relacionados a qualidade das tarefas técnicas e acompanhamento/controle. 


\section{5-CONCLUSÕES E RECOMENDAÇÕES}

Para cada estudo de caso foram apresentados dados de conjuntura sócio-econômica, motivação, patrocinadores, estrutura administrativa e um relato histórico de sua implementação, incluindo alguns resultados e perspectivas, sistemas internos existentes e serviços eletrônicos disponibizados a sociedade.

Importante destacar que foram identificados os principais fatores facilitadores e dificultadores percebidos em cada implementação e realizada uma discussão analítica para cada variável condicionante do processo, mostrando seu caratér propulsor e seu caráter inibidor, destacado pelos respondentes e pelas fontes de evidência complementares.

Com base em algumas referências de autores importantes, foi desenvolvida uma análise comparativa simplificada entre os casos, buscando inferir algumas semelhanças e diferenças em sua condução e resultados alcançados, e apresentando forças e fraquezas componentes de uma análise tipo SWOT.

Buscou-se ainda discutir a aderência dos resultados de campo com o referencial bibliográfico, através da formatação de um modelo conceitual de pesquisa usado para estruturar as entrevistas e analisar os resultados empíricos, apontando comparativamente elementos validados e não validados - ver Quadro resumo dos fatores condicionantes destacados pelos respondentes na página 140, incluíndo a segmentação de alguns fatores dispersos.

Destaca-se também a relevante contribuição do trabalho quando da construção e validação de um modelo conceitual de pesquisa para estudo de projetos de modernização na administração pública suportada pela TI. O modelo se mostrou adequado para derivar o roteiro de entrevista e captar de forma estruturada os elementos conceituais e empíricos mais relevantes de cada projeto-alvo.

Este referencial precisa ser evoluído e ajustado para servir a estudos específicos e de foco mais restrito, segmentando categorias específicas de informação que aglutinam aspectos dispersos nos agrupamentos do modelo-base. Levantou-se nos estudos de caso, alguns comentários adicionais e pontos de destaque que podem subsidiar eventuais ajustes no modelo inicial proposto, de modo a servir pesquisa de diferentes enfoques e objetivos na área pública, conforme descrito no ítem 5.2 Estudos Futuros.

Cabe ressaltar que as possibilidades de generalização e abrangência das conclusões desta investigação são limitadas pela utilização do método do Estudo de Caso e que as entrevistas foram conduzidas pelo 
pelo próprio pesquisador, complementada por outras fontes de evidência como observação direta e documentação dos projetos.

Finalmente podemos dizer que, se fosse possível difundir nos governos municipais uma palavra sobre o tema da Implementação de Projetos de Modernização Administrativa Municipal suportados pela TI, a escolhida seria cautela. Muitos vêm considerando a TI como uma panacéia ou como um sopro redentor das assimetrias, dos desequilíbrios e das contradições inerentes às nossas formações sociais. Isso é evidentemente um equívoco, sobretudo quando é alimentada a esperança de que o Estado sozinho seria capaz, com insumos tecnológicos, de conduzir a sociedade à superação dessa realidade.

A TI é simplesmente um meio para empreender soluções de caráter administrativo que visam maior eficácia e eficiência nos processo de trabalho, extremamente dependente das estratégias tradicionais, da perfeição das escolhas, do bom gerenciamento, da política que a orientará e da base material que sustenta o Estado. Caso contrário, a tecnologia pode servir de meio potente de desperdício de recursos, desarmonia de ações, aumento de entraves para procedimentos até simples e barreira intransponível para o exercício da transparência, da publicidade, da moralidade e da economicidade dos negócios públicos (Santos, 2002).

O que é, então, possível? Certamente usar a tecnologia não como um fim, mas como uma mediadora para a redução de um grande número dos problemas enfrentados pelos governos ao implementar os seus projetos e ao concretizar as suas opções, uma vez que cada governo quer queira, quer não, está submetido a uma série de interesses que precisa atender. A tecnologia, se realmente apropriada de forma racional, compromissada com resultados e visando à eliminação das disfunções próprias da burocracia, certamente servirá de incremento poderoso para as políticas de bem estar.

A melhor lição parece residir nas palavras de Cohen e Eimicke (2001) apud Santos (2002): "Da mesma maneira que as livrarias atualmente se beneficiam do fato de possuírem tanto lojas virtuais quanto físicas, os governos devem considerar que clientes com diferentes tipos de necessidade devem receber diferentes tipos de tratamento. Mesmo que a prestação de serviços governamentais via Internet não fosse uma boa idéia, muitos governos deveriam explorá-lo devido à demanda da população. Felizmente, há evidências claras de que a internet pode representar uma ajuda valiosa para o governo. É importante assegurar o cuidadoso planejamento dos serviços e a constante avaliação de seus custos e benefícios. (...) A internet é uma ferramenta e não uma panacéia."

As principais contribuições desta pesquisa dizem respeito:

口 À proposição de um modelo de análise do processo de Implementação de Projetos de Modernização Administrativa Municipal suportados pela TI, buscando identificar os 
principais fatores facilitadores e dificultadores deste processo na administração financeira e tributária de municípios paulistas Este modelo se baseou no espectro de gestão de projetos de sistemas de informação, elaborado por Pressman (2002), como um suporte adaptado para inserção das contribuições de diversos autores relacionados ao tema;

- À análise da situação atual e perspectivas futuras relacionadas com a implementação de projetos para modernização administrativa municipal suportada pela TI, verificando motivações, forças, fraquezas, oportunidades e ameaças percebidas no processo via estudo de casos nas administrações municipais de Santo André e São Paulo, à luz de referencial téoricoconceitual adequado.

Não existem ainda dados estatísticos de longo período, literatura científica vasta e experiências promissoras em grande número para permitir que se possa recomendar aos governos municipais medidas prévias que os guiem com acerto ao planejarem e implementarem Projetos de Modernização Administrativa Municipal suportados pela TI.

Importante destacar que todo projeto de Modernização Administrativa Municipal precisa levar em consideração que o Estado tem outras demandas e outras dívidas que se superpõem à modernização da prestação de serviço, pelo menos no Brasil, podendo ocasionar resultados frustrantes, daí, mais do que nunca, a necessidade de financiamentos não exclusivamente estatais e de esforços oriundos de diferentes parcerias, como a do mercado e das organizações não-governamentais. A parceira financeira e a adesão ao programa PMAT/BNDES por parte dos municípios-alvo desta pesquisa, legitima o processo e compartilha responsabilidades, além de incorporar "know-how" de implementações bem sucedidas e somar forças na condução das ações que realmente produzem resultados.

Cada organismo público e cada Prefeitura possuem suas peculiaridades e tendem a seguir opções muitas vezes diferentes daquelas que mais razoavelmente atendem ao maior número de governados com a eficiência e a eficácia esperadas - para a concepção, implementação e avaliação de seu projeto de modernização administrativa suportados pela TI.

Um ponto importante a se considerar e evidenciar numa análise comparativa entre os casos é a questão do porte/tamanho das prefeituras objeto da investigação. A prefeitura de São Paulo abriga uma realidade bem mais complexa que o município de Santo André, onde a máquina administrativa e os problemas enfrentados possuem escalas e características desproporcionais, que limitam qualquer análise ou julgamento de valor de um caso para outro.

Podemos especular que o modelo proposto pode ser aperfeiçoado buscando enfocar com maior 
profundidade os aspectos políticos da administração pública em detrimento da dimensão mais técnica ligada a administração de projetos e TI. Outro enfoque possível seria desenvolver e explicitar as linhas de ação ligadas a cada agrupamento de fatores que compõe o modelo conceitual.

Podemos especular também que o programa PMAT possui um caráter de "camisa de força", restringindo a autonomia estratégica-operacional da prefeitura alvo, este aspecto de certa inflexibilidade tem origem na forte influência do orgão financiador no planejamento e condução dos projetos de modernização administrativa. Neste mesmo contexto, a PRODAM - empresa de processamento de dados do município de São Paulo - por seu histórico de serviços prestados e sua condição privilegiada na área de TI, deveria ser alçada a posição de parceiro estratégico no projeto de modernização, contribuindo para maior eficiência e eficácia na sua implementação.

Cabe comentar aqui que o pesquisador possui perfil de participante do processo, já que presta serviço na prefeitura de São Paulo, prejudicando o viés de neutralidade da observação e coleta de evidências deste caso específico.

A seguir uma lista de recomendações mínimas de boas práticas relacionadas a implementação de processos de modernização da administração pública suportados pela TI, em especial pela tecnologia Internet:

- A comunicação social do governo não se deve limitar ao conhecimento da agenda do núcleo estratégico e político do Estado e ao enfoque da divulgação de conteúdo efêmero.

口 Não se deve consolidar o desequilíbrio econômico no acesso aos serviços públicos.

- Antes de implantar soluções de "governo eletrônico", que, muitas vezes, tendem a minimizar o custo do serviço para o próprio Estado, deve-se verificar e avaliar o risco de negligência na oferta do serviço de maneira completa.

- A resolução política dos conflitos de estabelecimento de uma infra-estrutura padronizada, unificada e controlada, bem como a formação de bancos de dados que se inter-relacionem e conversem entre si, sob uma mesma plataforma ou sob plataformas compatíveis, é pressuposto fundamental para o equilíbrio e a estabilidade das soluções adotadas.

- A escolha das aplicações precisa ser acertada, porque pode ser a última escolha.

口 É preciso por à disposição de todos, de forma planejada, antes de se pensar em criar novas infra-estruturas, a infra-estrutura existente nas próprias repartições públicas ou órgãos e nos organismos de controle estatal ou de outros entes federativos. Além disso, a aquisição dos equipamentos da tecnologia deve seguir o caminho das parcerias, da capacitação prévia, do bom conteúdo e da boa interface.

- A prestação de serviços eletrônicos dirigidos a um público-alvo especializado, que faz uso particular da informação que carrega valor agregado, deve ser cobrada pelo Estado. 
- Os "sites" oficiais relativos à prestação de serviços e ao provimento de informações devem ser regulados e normalizados de acordo com critérios internacionalmente aceitos e que visem à gestão por resultados.

- A performance dos países em desenvolvimento em conhecimento científico e em produção de tecnologia necessita ser alterada.

- O inventário que vem sendo acumulado sobre boas e más experiências em políticas de "governo eletrônico", precisa ser compartilhado entre os países. A pior prática é a imitação de realidades distintas da realidade interna de cada país.

- As metas fixadas pelos governos para as ações de "governo eletrônico" devem ter ambição moderada pela capacidade existente.

- As normas que regem o uso e os benefícios ou vícios decorrentes do emprego da TI devem ser conseqüência da instalação do processo, e não o contrário.

- A escolha e adoção de indicadores de desempenho e a avaliação de resultados das políticas de "governo eletrônico" devem ser medidas indispensáveis de análise dos programas.

- O bom governo não privilegia certos organismos do Estado na dotação de meios tecnológicos e de comunicações em detrimento de outros, acirrando a luta de interesses entre a área fiscal e a área social ou incentivando as escolhas que refletem critérios semelhantes aos usados no mercado.

口 É preciso esclarecer o conceito e os limites, no âmbito da democracia eletrônica, da democracia direta e da democracia indireta.

- As formas de "governo eletrônico" não devem se limitar à prestação de serviço e ao provimento de informações via Internet.

\section{1-Recomendações}

Neste item estão expostas sugestões aos administradores públicos municipais de alguma forma envolvidos em processos de Implementação de Projetos de Modernização Administrativa Municipal suportados pela TI.

Há que se desenvolver os portais internos e externos, eles são um novo canal de prestação de serviços públicos e de informação, mas também um canal de comunicação governo-sociedade, de mão dupla. Os governos vão oferecer serviços públicos, com processos interorganizacionais integrados, pela Internet ou pelos mecanismos tradicionais de prestação de serviços públicos. Poderão fazê-lo próativamente, sob o argumento de melhorar a prestação de serviços e informações à sociedade, ou reativamente, pela exigência da sociedade funcionando no novo paradigma de prestação de serviços que está sendo estabelecido pela iniciativa privada. O desenvolvimento dos portais está levando a 
ganhos percebidos pelos usuários, principalmente aqueles no exercício da sua atividade profissional, em tempo, em qualidade, em facilidade e no evitar deslocamentos. Para o governo, são percebidos ganhos em maior transparência, menores custos e ampliação da capacidade de atendimento (Cunha, 2000).

Na implantação de uma política de serviços eletrônicos ao cidadão pode ser adotada uma abordagem sistêmica e contingencial, que considere o ambiente, os componentes vs condicionantes, os atores envolvidos e as teorias existentes na administração pública. Alternativamente, pode ser adotada a abordagem de automatizar a prestação de serviços nos moldes existentes. A primeira traz a possibilidade de mudanças mais radicais e efetivas no relacionamento governo-cidadão. A segunda é pragmática, para situações onde as estruturas de governo não percebem o potencial da TI na alavancagem das ações de governo.

\section{2-Estudos futuros}

Este trabalho procurou obter uma visão panorâmica e exploratória do processo de Implementação de Projetos de Modernização Administrativa Municipal suportados pela TI. Estudos futuros podem avançar no conhecimento da utilização da TI no relacionamento da administração municipal com seus servidores e com o cidadão-contribuinte, envolvendo gerenciamento de mudanças nos processo de trabalho, qualidade, eficiência, eficácia e desburocratização da máquina administrativa

Alguns questionamentos importantes a serem pesquisados e que estão relacionados ao tema da modernização administrativa na área pública viabilizada pela TI:

- Quais os resultados efetivos alcançados e as expectativas não atingidas nas implementações de projetos de modernização suportadas pela TI já realizadas ou em estágio avançado de maturidade em prefeituras brasileiras?

- A redução de custos operacionais e o aumento da eficiência/eficácia na prestação de serviços ao cidadão pela Internet, considerando os custos diretos e indiretos de manipulação da tecnologia, é real e compensatório?

- Os processos tardios de implementação ou aqueles realizados com recursos escassos em prefeituras ou estados de menor porte possuem quais características especiais?

- Qual o nível de eficiência e os resultados alcançados por órgãos públicos que aderiram a programas de financiamento e repasse de conhecimento/tecnologia como o PMAT/BNDES?

- Quais as diferenças e similaridades existentes na implementação de projetos de modernização apoiados pela TI nas esferas federal, estadual e municipal no Brasil ? Quais as características 
comuns e específicas de projetos executados na administração direta - autarquias e fundações, e na administração indireta - empresas públicas e sociedades de economia mista ?

- Qual o comportamento das variáveis presentes no modelo de Pressman durante a evolução temporal do uso/adoção da TI para modernização administrativa das organizações públicas brasileiras?

Segundo Heekes e Davies (1999), os desafios da administração de TI para atender as necessidades do governo no século XXI (que podem representar áreas para pesquisa aplicada) são:

- Sistemas inter-relacionados que sejam confiáveis e seguros - As metodologias atuais de desenvolvimento de sistemas não atendem adequadamente o escopo e diversidade de usuários, clientes, e todos os envolvidos nos grandes sistemas de informação dos governos.

- Métodos e medidas de participação do cidadão no processo democrático - A tecnologia pode facilitar um envolvimento mais pessoal nas instituições e processos do governo. Acesso mais fácil do público à informação, votação eletrônica, plebiscitos, e outras possibilidades que promovem questões importantes acerca de cidadania, do papel das lideranças políticas e dos limites de mudança nas instituições democráticas.

- Modelos de serviços públicos eletrônicos e de sistemas de distribuição - Com a proliferação da Internet nas agências governamentais e entre os cidadãos, é possível oferecer novos serviços, e auto-serviço, de formas e em lugares em que jamais foi possível. Novos métodos de autenticação, "record-keeping", segurança e acesso são necessários, bem como novos métodos de medir custos e benefícios.

- Novos modelos de parcerias público-privado e outras formas organizacionais - Dada a diversidade de atores envolvidos na distribuição dos serviços governamentais, desenvolver sistemas efetivos baseados em TI muitas vezes requer novas coalizões de parceiros dentro de todas as esferas de governo, e entre o governo, iniciativa privada e terceiro setor. A complexidade dos relacionamentos organizacionais e tecnológicos resultantes é assustadora. Questões legais, econômicas, éticas, políticas e tecnológicas levam esta evolução a novos arranjos organizacionais.

- Arquivamento e gerenciamento de registros eletrônicos - Mais e mais informação reside em meios eletrônicos do que em arquivos físicos, gerando questões acerca de definição de conteúdo e registro, controle de versões, acesso público, preservação, e habilidade do governo manter história e transparência.

- Melhores métodos de gestão de TI - Executivos do governo precisam de formas de projetar e manter sistemas mais eficientes, flexíveis e potentes. Processos de design, projeto, gerenciamento de contratos, modelos de liderança e estratégias para lidar com falta de profissionais técnicos. 


\section{6-LIMITAÇÕES DA PESQUISA}

Assim como outros tipos de pesquisa, o Estudo de Caso tem suas limitações. Yin (1989) relaciona as principais críticas feitas aos estudos de caso:

- Falta de rigor - esse problema não é exclusivo do método do estudo de caso e sua ocorrência vai depender do esforço do pesquisador.

- Generalização - no estudo de caso, uma das principais limitações se refere justamente às generalizações, apesar de permitir uma verificação completa e profunda das variáveis escolhidas dentro da organização analisada, este tipo de pesquisa está limitado à situação estudada. Os estudo de caso são generalizáveis para proposições teóricas e não para populações ou universos.

- Tempo e relatórios - essa crítica diz respeito ao longo tempo consumido pelos estudos e aos relatórios gerados que podem ser de difícil e tediosa leitura. Yin não aceita essa crítica dizendo que é possível realizar um estudo de caso que não seja longo e cujo relatório seja feito de forma apropriada.

No sentido de maximizar a validade e a representatividade da pesquisa, a qualidade da investigação será garantida por meio de atenta observância e utilização dos quatro critérios básicos de Yin (1989) apresentados no capítulo da Metodologia de Pesquisa: utilização de definições realmente operacionais, múltiplas fontes de evidência, generalização analítica baseada firmemente em teoria bem elaborada e roteiro de pesquisa claro e detalhado viabilizando repetição. Importante ainda dizer que foram observados os princípios do uso de múltiplas fontes de evidência, desenvolvimento de um banco de dados do estudo e sustentação adequada das cadeias de evidência identificadas.

Algumas das limitações deste trabalho estão relacionadas à abrangência que se pretendeu dar ao estudo. Ao estudar-se o tema da Implementação de Projetos de Modernização Administrativa Municipal suportados pela TI, construiu-se uma visão panorâmica do assunto a partir da identificação dos principais fatores facilitadores e dificultadores do processo na administração financeiro-tributária de municípios paulistas. Esta visão abrangente careceu, por vezes, de um maior aprofundamento em aspectos específicos.

A velocidade das mudanças tecnológicas, ao se falar em tecnologia para Internet e apropriação dessas mudanças pelas estruturas de governo, foi um desafio a enfrentar, mas este estudo optou por não colocar o foco principal na tecnologia, o que atenua essa limitação. Há escassez de estudos sobre informática na área pública brasileira. A abrangência que se pretendeu dar, e o número reduzido de 
pesquisas acadêmicas disponíveis, orientaram a escolha por estudo de caso, o que limita a possibilidade de comparação com outros estudos que venham a ser produzidos.

Outro limitante está relacionado ao caráter subjetivo dos dados, já que se coletou a percepção dos respondentes das Entrevistas e existe o viés de interpretação do pesquisador responsável pela coleta de fontes de evidência complementares como a observação direta e documentos internos diretamente nas unidades de análise.

A implementação da modernização administrativa em Santo André notoriamente se encontra em estágio mais avançado do que em São Paulo, fato este que inviabiliza uma comparação simplista e direta do momento atual dos casos, por isso a preocupação e devida atenção dada ao enfoque histórico e ao contexto temporal neste trabalho 


\section{ANEXO I - Roteiros de Entrevistas}

As entrevistas serão realizadas pelo próprio pesquisador, no sentido de obter o máximo de informações possível, esclarecer eventuais dúvidas, conduzir o processo buscando otimizar o resultado final e ratificar a validade interna do estudo de caso. Este roteiro servirá de guia para as entrevistas, sendo que a ordem e a forma das perguntas, bem como a inclusão/exclusão de alguns tópicos serão feitos conforme a necessidade do entrevistador para otimização da coleta de informações, de acordo com as respostas dadas e o perfil dos respondentes.

Contexto do Projeto

1.1-Quando começaram os estudos para implementação do "Governo Eletrônico" na organização ?

1.2-Quem foi o pioneiro desta idéia?

Motivação

1.3-Quais os cenários e as necessidades iniciais?

1.4-Quais as motivações internas (valor estratégico da informática para o órgão, recursos alocados, desempenho anterior da função informática, organização e distribuição de poder ) ?

1.5-Quais as motivações externas (maior cobrança de serviços pela sociedade) ?

1.6--Quais são as metas e objetivos atuais ?

1.7-Quem definiu os objetivos?

Patrocínio

1.8-Como o projeto foi apresentado para a alta gerência ?

1.9-Quais as justificativas apresentadas?

1.10-Quem financiou o projeto de "Governo Eletrônico" no órgão ?

Fatores relacionados com PESSOAS (recursos humanos e ambiente)

2.1-Como funciona o recrutamento, a seleção e o treinamento de pessoal necessário para a equipe do projeto ? [dimensão Recursos Humanos - Pinto e Slevin: pessoal]

2.2-Qual o grau de competência dos líderes das equipes de projeto (administrativa, interpessoal e técnica) e a quantidade de autoridade disponível para desenvolver suas responsabilidades ? [dimensão Recursos Humanos - Pinto e Slevin: características do líder da equipe de projeto]

2.3-A equipe de projeto tem pessoal com as aptidões adequadas ? Utiliza-se consultoria externa ? [dimensão Recursos Humanos - John Reel e Pressman]

2.4-O pessoal envolvido utiliza as melhores práticas e lições aprendidas ? [dimensão Recursos Humanos - John Reel e Pressman]

2.5-Como o impacto dos fatores externos organizacionais ou ambientais influenciam na operação da 
equipe de projeto, tanto positivamente como negativamente ? [dimensão Ambiente - Pinto e Slevin: eventos ambientais]

2.6-O pessoal envolvido entende as necessidades de seus clientes ? Existe disposição para mudanças ? [dimensão Ambiente - John Reel e Pressman]

2.7-A turbulência do ambiente (realidades política e administrativa) é compatível com os longos prazos de maturação de projetos de sistemas ? [dimensão Ambiente - Reinhard]

Fatores relacionados com PRODUTO (produto final, relacionamento com o cliente e tecnologia)

3.1- Como está a percepção da importância do produto ou da necessidade de implementar o projeto tão rápido quanto possível ? [dimensão Produto Final - Pinto e Slevin: urgência]

3.2-O escopo do produto está definido de forma adequada ? [dimensão Produto Final - John Reel e Pressman]

3.3-Os usuários são resistentes ao produto/serviço ? [dimensão Produto Final - John Reel e Pressman] 3.4-Como funciona a comunicação, consulta e consideração ativa de todas as partes afetadas pelo projeto ? [dimensão Relacionamento com o Cliente - Pinto e Slevin:consulta ao cliente]

3.5-Como se procede o ato de vender o projeto para os usuários finais ? [dimensão Relacionamento com o Cliente - Pinto e Slevin: aceitação do cliente]

3.6-Busca-se prover uma visão completa do relacionamento com o cliente ? [dimensão Relacionamento com o Cliente - Seybold: foco no cliente final]

3.7-Como está a disponibilidade da tecnologia e especialização requeridas para completar as etapas de ação técnicas ? [dimensão Tecnologia - Pinto e Slevin: tarefas técnicas]

3.8-As tecnologias escolhidas sofrem modificações ? [dimensão Tecnologia - John Reel e Pressman]

3.9-Como funciona a seleção de tecnologia e sua integração ao legado ? [dimensão Tecnologia Pressman]

Fatores relacionados com PROCESSO (eficiência, controle e comunicação)

4.1-As necessidades de negócio modificam-se ou estão mal definidas ? [dimensão Eficiência - John Reel e Pressman]

4.2-O conceito de eficiência prioriza a atenção às normas sobre desempenho (ambientes fortemente regulados)? [dimensão Eficiência - Reinhard]

4.3-Como são mensuradas a eficiência e a eficácia dos projetos ? [dimensão Eficiência - Pressman]

4.4-Com funciona a obtenção e a disponibilização em tempo das informações de controle para cada fase no processo de implementação ? [dimensão Controle - Pinto e Slevin: monitoração e feedback] 4.5-Como são gerenciadas as modificações ? Como são tratadas as mudanças nos processos de negócio ? [dimensão Controle - John Reel e Pressman]

4.6-Os prazos estabelecidos são adequados ? [dimensão Controle - John Reel e Pressman] 
4.7-Com funciona a obtenção e a disponibilização de uma rede apropriada e dos dados necessários para todos os fatores chave na implementação do projeto ? [dimensão Comunicação, Pinto e Slevin: comunicação]

4.8-Com está a habilidade de tratar crises inesperadas e desvios em relação aos planos ? [dimensão Comunicação - Pinto e Slevin: solução de problemas).

4.9-A rede de comunicação com a organização e sua administração é adequada (relações públicas e aprendizagem organizacional) ? [dimensão Comunicação - Reinhard]

Fatores relacionados com PROJETO (estratégia e planejamento)

5.1-Existe disposição da alta gerência em prover os recursos e autoridade/poder necessários para o sucesso do projeto ? [dimensão Estratégia - Pinto e Slevin: apoio da alta gerência]

5.2-A alta administração reconhece o papel estratégico da TI, obtem os recursos e estabelece vínculos adequados com a função de informática ? [dimensão Estratégia - Reinhard]

5.3-Como não perder a visão estratégica necessária para construir operações de TI eficazes no longo prazo (competência política e o comportamento oportunístico) ? [dimensão Estratégia - Reinhard]

5.4-O patrocínio foi obtido adequadamente ? [dimensão Estratégia - John Reel e Pressman]

5.5-Como está a definição e clareza dos objetivos, metas e direções gerais ? [dimensão Planejamento

- Pinto e Slevin: missão do projeto]

5.6-Existe uma especificação detalhada das etapas individuais de ação requerida para a implementação do projeto ? [dimensão Planejamento - Pinto e Slevin: planos e cronogramas]

5.7-Busca-se resultados de curto prazo em detrimento da eficácia de longo prazo ? [dimensão Planejamento - Reinhard]

Fatores relacionados com a Implementação de TI na Administração Pública: consultoria externa, implantação de produtos e infra-estrutura.

6.1- Qual o grau de influência que uma eventual contratação de especialistas externos em TI provoca na definição da infra-estrutura tecnológica da organização ? [Implementação de TI na Administração Tributária - Modelo de Netto]

6.2- A implantação de novos produtos e o eventual incremento da infra-estrutura de TI reflete um efeito catalisador incentivado pela contratação de consultores externos ? [Implementação de TI na Administração Tributária - Modelo de Netto]

6.3- A efetiva disponibilização dos produtos colabora para diminuir resistências internas culturais e políticas ? [Implementação de TI na Administração Tributária - Modelo de Netto]

6.4- Qual o grau de influência que uma infra-estrutura de TI deficiente ou inadequada provoca no trabalho dos consultores externos e na implantação de novos produtos ? [Implementação de TI na Administração Tributária - Modelo de Netto] 


\section{REFERÊNCIAS BIBLIOGRÁFICAS}

AFONSO, José R.R.; CORREIA, Cristóvão A.;ARAÚJO, Erika A ; RAMUNDO, Júlio C. M.; DAVID, Maurício D.; SANTOS, Rômulo M. dos.; Municípios; Arrecadação e Administração Tributária: quebrando tabus. Revista do BNDES; dez. 1998.

ALBERTIN, Alberto. L. Comércio eletrônico : um estudo no setor bancário. Tese (Doutorado) Faculdade de Economia, Administração e Contabilidade da Universidade de São Paulo. São Paulo, 1997.

ALBERTIN, Alberto. L. Comércio eletrônico : modelo, aspectos e contribuição de sua utilização. 2. ed. São Paulo: Atlas, 2000.

ALBERTIN, Alberto. L. Valor estratégico dos projetos de TI. RAE - Revista de Administração de Empresas, V. 41, n. 03, p. 42-50. São Paulo, jul/set 2001.

AMOR, Daniel, A (R) evolução do E-business, Makron Books, 2000.

BAKER, B.N.; MURPHY, D.C.; FISCHER, D. Factors Affecting Project Success. The Successfull Applicattion of Project Management. September, 1974.

BACKUS, MICHIEL. E-Governance and Developing Countries. Researh Report, N. 03, Abril, 2001.

BALUTIS A. P. (1999) - Digital Government - When All is Said and Done, Electronic Government Journal, Vol. 2, No. 6, November

BLOCH, M.; PIGNEUR, Y.; SEGEV A. On the road of electronic commerce : a business value framework, gaining competitive advantage and some research issue. Lausanne : Institut d'Informatique et Organisation; Ecole des Hautes Etudes Commerciales, Université de Lausanne, 1996.

BONOMA, Thomas V.; Case research in Marketing: opportunities, problems and a process - EUA: Journal of Marketing Research. May, 1985. Vol. XXII, p. 199-208.

CAMPOMAR, M. Cortez; Do uso do "estudo de caso" em pesquisas para dissertações e teses em administração - Revista de Administração, São Paulo, FEA-USP, Julho-Setembro, 1991, v.26. n.3. p.95-97. 
COHEN, S.; EIMICKE, W. A utilização da internet na prestação de serviços governamentais. Rio de Janeiro: PWC CONSULTING, 2001. 47p.

CRUZ, M.G.,RAINS, L.C; "Lições Aprendidas em Programas de Modernização da Gestão Pública Estudo de caso: a gestão fiscal", Em: Seminário Internacional sobre Modernização das Fazendas Públicas Estaduais, Secretaria de Estado da Fazenda de Pernambuco, setembro de 2001.

CRUZ, Maurício S. TI no espaço público : o caso Telecidadão no Paraná. Dissertação (Mestrado) Escola de Administração de Empresas de São Paulo da Fundação Getúlio Vargas. São Paulo, 1999.

CUNHA, M. A. V. C.; MORGADO, E; REINHARD, N. Preocupações estratégicas dos executivos de informática pública. Encontro Nacional de Programas de Pós-graduação em Administração. Anais. Angra dos Reis, 1996.

CUNHA, M. A. V.C., Portal de serviços públicos e de informação ao cidadão: estudos de caso no Brasil - Tese (Doutorado), São Paulo, FEA-USP, 2000.

DeCOTIIS, T.A. \& DIER, L. Defining and Measuring Project Performance. Research Management. January, 1979, pp 17-22.

DINIZ, Eduardo H., Uso do comércio eletrônico em órgãos do governo - Série Relatórios de Pesquisa - NPP/EAESP/FGV. São Paulo: Relatório no 18/2000

DINSMORE, P. C. The AMA handbook of project management. American Management Association, 1993.

ELMASRI, Ramez; NAVATHE, Shamkant B. Fundamentals of database systems. 3.ed. Atlanta: Addison-Wesley, 2000.

EMPLASA. Manual do Curso de Sistemas de Informações para Planejamento e Modernização da Administração Tributária. Empresa Paulista de Planejamento Metropolitano S/A, 1A Edição, Agosto2001.

FERNANDES, Andréa. G. E-Governo no Brasil - Estudo da Secretaria para Assuntos Fiscais do Banco Nacional de Desenvolvimento Econômico e Social (SF/BNDES). XIII Seminário Regional de Política Fiscal. Santiago, 2001. 
FERNANDES, Andréa. G. E-Governo: o que já fazem estados e municípios. Revista Informe-se, n. 20. Secretaria para Assuntos Fiscais do Banco Nacional de Desenvolvimento Econômico e Social (SF/BNDES). Brasília, out/2000.

GODOY, Arilda S., Introdução à pesquisa qualitativa e suas possibilidades - São Paulo: Revista de Adm. de Empresas, Março/Abril 1995a - v.35 n.2 p. 57-63.

GODOY, Arilda S., Pesquisa qualitativa: tipos fundamentais - São Paulo: Revista de Adm. de Empresas, Maio/Junhol 1995b - v.35 n.3 p. 20-29.

HEEKS, R. \& DAVIES A. Different approaches to information age reform. In : Heeks, R. (ed.). Reinventing government in the information age : international practice in IT-enabled public sector reform. London : Routledge, 1999. 386 p.

HOLDEN, Stephen, H. The evolution of Information Technology management at the federal level : implications for public administration. In : Garson, David G. Information Technology and computer applications in public administration : issues and trends. USA : Idea Group Publishing, 1999. p. 304.

KERZNER, H. Project management: a systems approach to planning, schedulling and controlling. New York: Van Nostrand Reinhold, 1995.

KRAEMER, K. L. Managing information systems. In : Perry J. L. The corporation of the 1990's. New York : Oxford University Press, 1991.

KRAEMER K.L. \& DEDRICK J. (1997) - "Computing and Public Organizations", Em: Journal of Public Administration Research and Theory,7, 1:89-112.

KWON, Tae H.; ZMUD, Robert W. Unifying the fragmented models of information systems implementation. In : Boland, R. J.; Hirschheim, R. A. (ed.). Critical issues in information systems research. John Wiley, 1987.

LAUDON, K. \& LAUDON, J. Management information systems : organization and technology in the networked enterprise. 6. ed. New Jersey : Prentice Hall, 2000.

LEITE, Jaci C., Imposto de Renda via Internet: inovando em serviços públicos através da TI. In: XXII ENANPAD. Anais. Foz do Iguaçu, 27 a 30 de setembro de 1998. 
LENK K. \& TRAUNMULLER R. (2001) - "Broadening the Concept of Electronic Government", Em: Designing E-Government, Prins J.E.J. (ed.), Kluwer Law International, pp. 63-74

MARCHANT, Diego A . C. \& MARTINELLI, Luis F. S. A Internet a serviço do Fisco. Em: O direito na era virtual. Lacaz martins, Halembeck, Pereira Neto, Gurevich \& Schoueri Advogados. São Paulo, 2000.

MAXIMINIANO, A. C. A. Administração de Projetos : Como transformar idéias em resultados. São Paulo. Atlas, 1997.

NETTO, Francisco S., Posto Fiscal Eletrônico: alguns elementos propulsores e inibidores do uso de soluções informatizadas na modernização da prestação de serviços públicos na administração pública direta brasileira. Dissertação (Mestrado) FACEF - Faculdade de Ciências Econômicas, Administrativas e Contábeis de Franca, 2000.

NOLAN, R. Managing the crisis in data processing. Harvard Business Review, USA, Mar./Abr. 1979.

PARDO, Theresa A. Reducing the risks of innovative uses of information technology in the public sector : a multidisciplinary model. New York : University at Albany, State University of New York, 1998.

PERRI 6 (2001) - "E-governance. Do Digital Aids Make a Difference in Policy Making?", Em: Designing E-Government, Prins J.E.J. (ed.), Kluwer Law International, pp. 7-27

PINTO, J. K. \& SLEVIN, D. P., Critical sucess factors across the project life cycle. Project Management Journal, vol. XIX, n. 01, Feb, 1988.

PINTO, S.A.O. Gerenciamento de Projetos: Análise dos fatores de risco que influenciam o sucesso de projetos de sistemas de informação. São Paulo. 208p. Dissertação (Mestrado) - Faculdade de Economia, Administração e Contabilidade. Universidade de São Paulo, 2002.

PMBOK, V 1.0, Gerência de Projetos. Tradução livre disponibilizada através da Internet pelo PMI MG, maio de 2000 .

PORTER, Michael. Estratégia competitiva : técnicas para análise de indústrias e da concorrência. 8. ed. Rio de Janeiro : Campus, 1991. 
PRESSMAN, R.. Engenharia de Software. 5a edição, McGraw Hill, 2002.

REINHARD, Nicolau. Informatização no governo federal. Em: Revista de administração, São Paulo, v. 28, n. 2, p. 117-121, Abr./Jun. 1993.

REINHARD, Nicolau., A Internet mudou tudo? In : Congresso Nacional de Informática Pública. São Paulo, 1999. (Anotações livres não revisadas pelo autor).

SANTOS, R. J. L. - "Governo Eletrônico": o que se deve e o que não se deve fazer, Em: XVI Concurso de Ensayos y Monografías del CLAD sobre Reforma del Estado y Modernización de la Administración Pública. Em: "Gobierno Electrónico". Caracas, 2002.

SBRAGIA, Roberto; ROBIC, André R.; Sucesso em projetos de informatização: critérios de avaliação e fatores condicionantes. Revista Economia de Empresas, São Paulo, v. 02, n.3, jul/set 1995.

SEYBOLD, P. B. \& MARSHAK, R. T. Clientes.com: como criar um estratégia empresarial para a Internet que proporcione lucros reais. São Paulo. Makron Books, 2000.

TURBAN, Efraim; McLEAN, Ephraim; WETHERBE, James. Information technology for management: making connections for strategic advantage. 2.ed. New York: John Wiley \& Sons, 1999.

VENKATRAMAN, N. IT-induced business transformation. In : Scott Morton, M. (ed.) The corporation of the 1990's. New York : Oxford University Press, 1991.

WETHERBE, J.C. Four stage Model for MIS Planning, Concept, Techniques, and Implementation. No Banker, R. D., Kaufmann, R. J. e Mahmood, M. A. (ed.). Strategic Information Technology Management: perspectives on organizational growth and competitive advantage. London: Idea Group Publishing, 1993.

YIN, R.K., Case Study Research: Design and methods - California: Sage Publications, 1989.

ZWEERS K., PLANQUÉ K; "Electronic Government. From a Organizational Based Perspective Towards a Client Oriented Approach", Em: Designing E-Government, Prins J.E.J. (ed.), Kluwer Law International, pp. 92, 2001. 